\title{
Recent Development of Carbonaceous Materials for Lithium-Sulphur Batteries
}

\author{
Xingxing Gu, Luke Hencz and Shanqing Zhang * \\ Centre for Clean Environment and Energy, Griffith School of Environment, Griffith University, \\ Gold Coast Campus, QLD 4222, Australia; xingxing.gu@griffithuni.edu.au (X.G.); \\ luke.hencz@griffithuni.edu.au (L.H.) \\ * Correspondence: s.zhang@griffith.edu.au; Tel.: +61-7-5552-8155
}

Academic Editor: Joeri Van Mierlo

Received: 12 September 2016; Accepted: 8 November 2016; Published: 14 November 2016

\begin{abstract}
The effects of climate change are just beginning to be felt, and as such, society must work towards strategies of reducing humanity's impact on the environment. Due to the fact that energy production is one of the primary contributors to greenhouse gas emissions, it is obvious that more environmentally friendly sources of power are required. Technologies such as solar and wind power are constantly being improved through research; however, as these technologies are often sporadic in their power generation, efforts must be made to establish ways to store this sustainable energy when conditions for generation are not ideal. Battery storage is one possible supplement to these renewable energy technologies; however, as current Li-ion technology is reaching its theoretical capacity, new battery technology must be investigated. Lithium-sulphur (Li-S) batteries are receiving much attention as a potential replacement for Li-ion batteries due to their superior capacity, and also their abundant and environmentally benign active materials. In the spirit of environmental harm minimization, efforts have been made to use sustainable carbonaceous materials for applications as carbon-sulphur (C-S) composite cathodes, carbon interlayers, and carbon-modified separators. This work reports on the various applications of carbonaceous materials applied to Li-S batteries, and provides perspectives for the future development of $\mathrm{Li}-\mathrm{S}$ batteries with the aim of preparing a high energy density, environmentally friendly, and sustainable sulphur-based cathode with long cycle life.
\end{abstract}

Keywords: lithium-sulphur (Li-S) batteries; carbon-sulphur (C-S) composites; carbon interlayers; carbon modified separators; high energy density

\section{Introduction}

The ever-growing economy and increasing global population boost the demand of energy, which is typically derived from fossil fuel sources [1]. Unfortunately, the combustion of fossil fuels causes widespread social concerns about environmental pollution and climate change [2]. Therefore, sustainable and green energy sources (i.e., wind power, solar energy, and hydropower) are regarded as long-term renewable energy alternatives to alleviate the environmental problems which arise from the combustion of fossil fuels. Practical utilization of these intermittent power sources would not succeed without the development of low cost and high capability energy storage technologies. Until now, rechargeable lithium-ion batteries (LIBs) have been the most promising electrochemical energy storage system, as they have dominated the portable electronics market because of their high energy density [1]. However, the state-of-the-art of conventional LIBs (graphite/ $\mathrm{LiCoO}_{2}$ cells)-even at their theoretical capacity $\left(387 \mathrm{Wh} \cdot \mathrm{kg}^{-1}\right.$ ) [3] - are not capable of meeting future energy storage requirements for electric vehicle transportation, as well as portable and residential applications [1]. Therefore, exploration of 
new energy storage systems based on different electrochemistry is urgently needed to go beyond incremental improvements in the specific energy of existing batteries.

Lithium-sulphur (Li-S) batteries have the potential advantage of breaking the storage limits of conventional LIBs. As shown in Figure 1, the gravimetric/volumetric energy densities of LIBs and Li-S batteries have been compared. On one hand, sulphur shows the highest theoretical capacity of $1675 \mathrm{~mA} \cdot \mathrm{h} \cdot \mathrm{g}^{-1}$ among solid cathode elements [1,4]. On the other hand, the matched lithium anode also owns a superior high theoretical capacity of $3861 \mathrm{~mA} \cdot \mathrm{h} \cdot \mathrm{g}^{-1}$ [5]. Thus, given that Li-S batteries operate on the basis of a stoichiometric redox chemistry between sulphur and lithium, Li-S batteries can reach a theoretical specific energy and volumetric energy density of approximately $2600 \mathrm{~W} \cdot \mathrm{h} \cdot \mathrm{kg}^{-1}$ and $2800 \mathrm{~W} \cdot \mathrm{h} \cdot \mathrm{L}^{-1}$, respectively (based on the complete $\mathrm{Li}_{2} \mathrm{~S}$ formation) [6]. The remarkable storage capacity permits electric vehicles to possess a driving range of $\sim 500 \mathrm{~km}$ after a single charge [1,3]. Moreover, sulphur is an attractive electroactive material for cathodes because it is naturally abundant, low cost, and environmentally friendly [7]. According to the above advantages of sulphur, it is anticipated that $\mathrm{Li}-\mathrm{S}$ batteries will ultimately rebuild the current energy infrastructure if the technology succeeds.

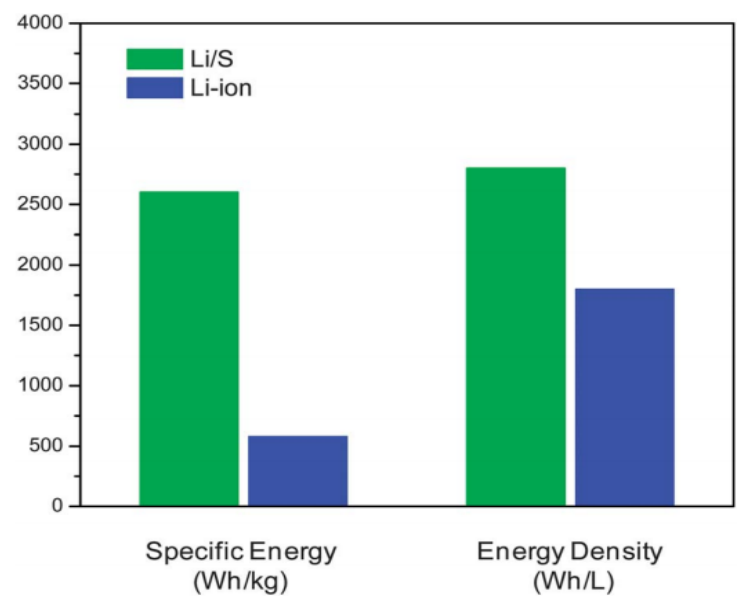

Figure 1. Comparison of theoretical specific energy and energy density of the lithium/sulphur (Li/S) cell with those of current lithium-ion batteries (LIBs) [6]. Reproduced with permission from [6]. Copyright 2013, Royal Society of Chemistry.

\subsection{Working Mechanism of Lithium-Sulphur Batteries}

A rechargeable Li-S battery consists of the following primary functional components: a positive electrode (cathode), a negative electrode (anode), electrolyte, and a micro-porous membrane (separator). The operation of rechargeable Li-S batteries is simply based on the theory of $\mathrm{Li}$ ions migrating between the cathode and the anode through the electrolyte. In order to achieve high cycling efficiency and long life, the movement of $\mathrm{Li}$ ions in anode and cathode hosts should not change or damage the host crystal structure. Figure 2 shows a typical Li-S cell, in which the cathode consists of sulphur (yellow) and a conductive additive (black; for example, carbon black), and a metallic lithium anode which is separated by an organic electrolyte [8].

The electrochemical reactions that occur at the cathode and anode are shown in the following equations:

$$
\begin{gathered}
\mathrm{S}_{8}+2 \mathrm{Li}^{+}+2 \mathrm{e}^{-} \rightarrow \mathrm{Li}_{2} \mathrm{~S}_{8} \\
3 \mathrm{Li}_{2} \mathrm{~S}_{8}+2 \mathrm{Li}^{+}+2 \mathrm{e}^{-} \rightarrow 4 \mathrm{Li}_{2} \mathrm{~S}_{6} \\
2 \mathrm{Li}_{2} \mathrm{~S}_{6}+2 \mathrm{Li}^{+}+2 \mathrm{e}^{-} \rightarrow 3 \mathrm{Li}_{2} \mathrm{~S}_{4} \\
\mathrm{Li}_{2} \mathrm{~S}_{4}+2 \mathrm{Li}^{+}+2 \mathrm{e}^{-} \rightarrow 2 \mathrm{Li}_{2} \mathrm{~S}_{2} \\
\mathrm{Li}_{2} \mathrm{~S}_{2}+2 \mathrm{Li}^{+}+2 \mathrm{e}^{-} \rightarrow 2 \mathrm{Li}_{2} \mathrm{~S}
\end{gathered}
$$




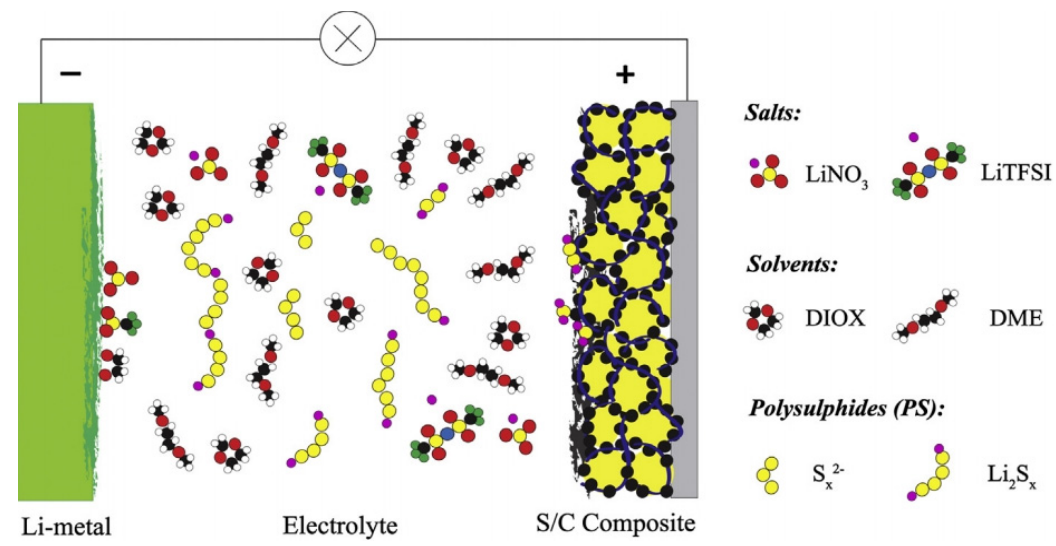

Figure 2. Schematic illustration of a typical lithium-sulphur (Li-S) cell [8]. Reproduced with permission from [8]. Copyright 2014, Elsevier. LiTFSI: lithium bis (trifluoromethylsulfonyl)imide; DIOX: dioxane; and DME: dimethoxyethane.

The first three steps correspond to the high plateau (2.3-2.4 V) in the voltage profile (Figure 3), and the polysulphide species produced in these steps are soluble in the electrolyte [5]. In the last two steps, insoluble $\mathrm{Li}_{2} \mathrm{~S}_{2}$ and $\mathrm{Li}_{2} \mathrm{~S}$ are formed and precipitate out at the cathode. The corresponding voltage is lower, as indicated by the long plateau at around $2.1 \mathrm{~V}$. The first four steps have fast or moderate kinetics, while the last step of converting $\mathrm{Li}_{2} \mathrm{~S}_{2}$ to $\mathrm{Li}_{2} \mathrm{~S}$ is difficult, and is impeded by slow solid-state diffusion. Consequently, the voltage drops rapidly once $\mathrm{Li}_{2} \mathrm{~S}$ covers the whole electrode framework, resulting in the termination of discharge.

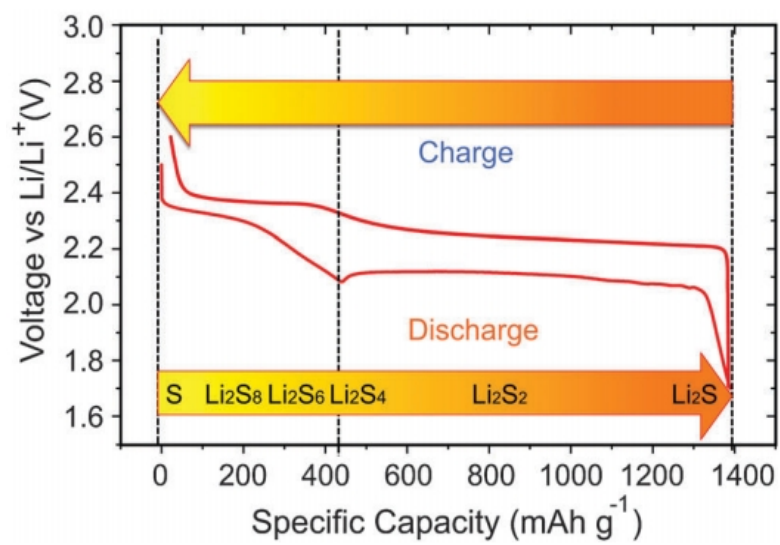

Figure 3. The voltage profile and chemistry of sulphur cathode in the organic electrolyte [5]. Reproduced with permission from [5]. Copyright 2013, Royal Society of Chemistry.

\subsection{The Challenges of Lithium-Sulphur Batteries for Commercialization}

\subsubsection{Poor Electrical Conductivity of Sulphur and $\mathrm{Li}_{2} \mathrm{~S} / \mathrm{Li}_{2} \mathrm{~S}_{2}$}

First of all, the insulating nature of sulphur $\left(5 \times 10^{-30} \mathrm{~S} \cdot \mathrm{cm}^{-1}\right.$ at $\left.25^{\circ} \mathrm{C}\right)$ causes remarkably low utilization and poor rate capability [9-11]. Moreover, the polysulphides that are produced during cycling are further reduced to insulating $\mathrm{Li}_{2} \mathrm{~S}_{2}$ and $/$ or $\mathrm{Li}_{2} \mathrm{~S}$, which also significantly decreases the electrode kinetics and cycling capacities.

\subsubsection{Dissolution of Polysulphides and the Related Shuttle Effect}

Secondly, the polysulphides which are formed upon cycling can easily dissolve in the organic electrolyte, where they possess high mobility. Dissolved polysulphide anions $\left(\mathrm{S}_{x}{ }^{2-}\right)$ can diffuse 
through the separator to the negative electrode, where they undergo chemical reactions with the lithium metal, leading to the loss of sulphur from the positive electrode, corrosion of the lithium metal, and self-discharge, which influences the electrochemical utilization of sulphur (i.e., discharge capacity), rate capability, and cycle life of Li-S cells [6,12]. Meanwhile, such dissolution and diffusivity will result in the so-called shuttle phenomenon. When discharging, the elemental sulphur is reduced to form soluble high-order polysulphides at the sulphur electrode, which creates a concentration gradient inside the cell. Due to the high concentration of high order polysulphides at the cathode, the diffusion of high order polysulphides towards the anode is observed, which enables the high order polysulphides to react with the lithium anode to form low order polysulphides. This in turn creates a high concentration of low order polysulphides located at the anode of the cell, which diffuse back to the cathode in order to be oxidized back to high order polysulphides. This phenomenon-the diffusion back and forth of polysulphides between the two electrodes-is known as the "polysulphide shuttle" [13]. This shuttle phenomenon will result in extremely low Coulombic efficiency and quick/rapid capacity fading [6].

\subsubsection{Self-Discharge}

The dissolution of the polysulphides brings about another serious problem-the severe self-discharge observed in Li-S batteries. The sulphur-based species could migrate to the anode side and be converted to polysulphides, leading to a decrease in the open-circuit voltage and discharge capacity.

\subsubsection{Volume Expansion}

Last but not least, the great volume/morphology change of the $\mathrm{S}$ electrode during cycling is another critical factor hindering the large scale commercialisation of $\mathrm{Li}-\mathrm{S}$ batteries. The deterioration of microstructure or architecture of the electrodes associated with the volume expansion/contraction $(\sim 76 \%)$ and morphology change of the S electrode material during cycling will lead to poor cycling performances of $\mathrm{Li}-\mathrm{S}$ batteries, as the volume expansion of electroactive material can damage the electrical connectivity of the carbon host at the cathode [6].

\subsection{Strategies for Improving the Performances of Lithium-Sulphur Batteries}

As mentioned above, there are many kinds of factors that inhibit the commercialization of Li-S batteries. The strategy for improving a single component may not be able to address all of the issues that are interlinked. More comprehensive approaches are required to remedy this complicated situation in order to dramatically improve the cycling stability and rate capability of Li-S cells.

To date, researchers have proposed various strategies, such as embedding the sulphur into porous and hollow carbon $[9,14-17]$, limiting the polysulphides shuttle through the use of interlayers $[7,18,19]$, fabricating sulphur electrodes with conductive carbon and polymers [20-24], impregnating the carbon hosts with metal oxides (e.g., $\mathrm{TiO}_{2}, \mathrm{ZnO}, \mathrm{MnO}_{2}$ ) [25-28], and metal organic frameworks (MOFs) [29-31] to enhance the adsorption for polysulphides species, as well as developing new types of separators, electrolytes, and binders [32-36], etc., in order to tackle the issues of $\mathrm{Li}-\mathrm{S}$ batteries. Among them, the strategies of restricting the sulphur within conductive carbon frameworks have proven to be promising. The following sections systematically introduce the roles and the effectiveness of carbon-based materials for the cathode of Li-S batteries.

\section{Carbonaceous Materials for the Cathode of Lithium-Sulphur Batteries}

It is commonly regarded that the conductivity, specific surface area, and pore volumes of the various carbonaceous materials are the critical factors that affect the electrochemical performance of a sulphur cathode. With respect to practical applications, one must also take the costs of reagents during materials synthesis into consideration. Therefore, as outlined in Table 1, a set of generic advantages and disadvantages of the commonly used carbon frameworks can be established. 
Table 1. Advantages and disadvantages of various carbonaceous materials in Li-S batteries. CNTs: carbon nanotubes; and BET: Brunauer, Emmett and Teller.

\begin{tabular}{ccccc}
\hline Carbon Type & Porous Carbon & Carbon Nanospheres & CNTs & Graphene \\
\hline Price & Cheap & Medium & Expensive & Expensive \\
Conductivity & Good & Good & Excellent & Excellent \\
BET surface area & High & Medium & Medium & Low \\
Pore volume & High & Medium & Low & High \\
\hline
\end{tabular}

\subsection{Porous Carbon for the Lithium-Sulphur Electrode}

A porous carbon-sulphur (C-S) composite is a mixture of porous carbon and sulphur, where sulphur is mainly encapsulated inside the carbon pores. The porous carbon matrix can not only help trap the dissolved polysulphides, but the nanopores can also accommodate the volume expansion which is displayed upon cycling [5]. Additionally, the conductive carbon matrix can improve the electrical conductivity of the electrode, which can improve the reaction kinetics and the active material utilization [5,14]. Depending on which pore sizes are present, porous carbons can be classified into three categories: (1) micropore ( $D \leq 2 \mathrm{~nm}$ ); (2) mesopore ( $2 \mathrm{~nm} \leq D \leq 50 \mathrm{~nm}$ ); and (3) macropore $(D \geq 50 \mathrm{~nm})$. Each type of porous carbon possesses unique properties and morphological advantages.

Before investigating the various types of porous carbon employed in Li-S cells, one must consider the way in which sulphur is encapsulated into the porous carbon matrix. The most common methods are melt-diffusion and chemical in situ deposition. The melt diffusion method is to inject the melted sulphur into the pores of carbonaceous materials, offering the advantage of simplicity but the disadvantage of uneven distribution of sulphur throughout the carbonaceous structure. In contrast, the chemical in situ deposition method can distribute the sulphur homogeneously into materials. The resultant electrode can commonly achieve fast reaction kinetics and eliminate severe polarization. However, this is commonly achieved at the cost of much longer time and expensive instrumentation (e.g., deposition for $16 \mathrm{~h}$ with electrochemical workstation) [37].

\subsubsection{Microporous Carbon-Sulphur Composites}

Micropores were shown to help improve the cycle life of Li-S batteries by effectively confining polysulphide diffusion in the organic electrolyte [38]. Following this, researchers have developed many kinds of microporous carbon as the sulphur host for Li-S batteries [38-47] (as shown in Table 1), among which sucrose as the carbon source is most popular; i.e., a microporous graphitic carbon of high surface $1416 \mathrm{~m}^{2} \cdot \mathrm{g}^{-1}$ and high pore volume of $1.11 \mathrm{~cm}^{3} \cdot \mathrm{g}^{-1}$ was prepared by using commercial $\mathrm{CaCO}_{3}$ nanoparticles as a template with sucrose as a carbon source, followed by $1200{ }^{\circ} \mathrm{C}$ high-temperature calcination [43]. Sulphur/porous graphitic carbon composites with ultra-high sulphur loading of $88.9 \mathrm{wt} \%$ ( $88.9 \% \mathrm{~S} / \mathrm{PC})$ and lower sulphur loading of $60.8 \mathrm{wt} \%(60.8 \% \mathrm{~S} / \mathrm{PC})$ were both synthesized by a simple melt-diffusion strategy. When their electrochemical performances were investigated, the $88.9 \% \mathrm{~S} / \mathrm{PC}$ exhibited a higher overall discharge capacity of $649.4 \mathrm{~mA} \cdot \mathrm{h} \cdot \mathrm{g}^{-1}$ (according to $\mathrm{C}-\mathrm{S}$ composite), higher capacity retention of $84.6 \%$ and better Coulombic efficiency of $97.4 \%$ after 50 cycles at a rate of $0.1 \mathrm{C}$ when compared with the $60.8 \% \mathrm{~S} / \mathrm{PC}$ sample. Gao's group [45] synthesized microporous carbon spheres by refluxing sucrose ( $5 \mathrm{wt} \%$ solution) in $6 \mathrm{M}$ sulphuric acid at $120^{\circ} \mathrm{C}$ for $10 \mathrm{~h}$ and carbonized the black product at $1000^{\circ} \mathrm{C}$ for $2 \mathrm{~h}$ under flowing Ar gas. The obtained carbon spheres only displayed micropores, measuring about $0.7 \mathrm{~nm}$, with no mesopores being detected. This composite was stable for 500 cycles, which was related to the strong adsorption of polysulphides by the narrow micropores [45]. They also observed lithiation potential hysteresis during the discharge process, which reflects the additional energy required to overcome the adsorption energy of the short chain sulphur trapped in micropores when using the carbonic ester electrolyte [45]. Similar cathode behaviour of sulphur in microporous carbon was reported by Huang's group [40]. 
In addition to the dissolution of soluble polysulphides in organic electrolyte, irreversible $\mathrm{Li}_{2} \mathrm{~S}$ formation also caused poor cycling stability [44]. Recently, a new C-S cathode material comprising short-chain sulphur species (predominately $\mathrm{S}_{2}$ ) confined in microporous carbonaceous could separate the $\mathrm{Li}^{+} / \mathrm{S}^{2-}$ ion couple, which can preclude $\mathrm{Li}_{2} \mathrm{~S}$ compound formation and prevents the dissolution of soluble sulphur anions [44]. This new charge/discharge process leads to remarkable cycling stability and reversibility—the C-S cathode stably delivered $\sim 600 \mathrm{~mA} \cdot \mathrm{h} \cdot \mathrm{g}^{-1}$ capacity over 4020 cycles $\left(0.0014 \%\right.$ loss cycle $\left.{ }^{-1}\right)$ at $\sim 100 \%$ Coulombic efficiency.

In addition, Lu's group [37] developed an electrolysis approach that allowed effective and uniform incorporation of sulphur inside the micropores of carbon nanosheets for advanced Li-S batteries, as shown in Figure 4a. The sulphur-carbon hybrid can be prepared with $70 \mathrm{wt} \%$ sulphur loading, in which no nonconductive sulphur agglomerations are formed. Because the incorporated sulphur is electrically connected to the carbon matrix in nature [37], the hybrid cathode shows excellent electrochemical performance; i.e., the monolithic carbon-2 (MLC-2) with $\sim 65 \mathrm{wt} \%$ sulphur showed a high capacity of $612 \mathrm{~mA} \cdot \mathrm{h} \cdot \mathrm{g}^{-1}$ retained after 500 cycles, corresponding to a capacity retention of $\sim 60 \%$, as shown in Figure $4 \mathrm{~b}$.

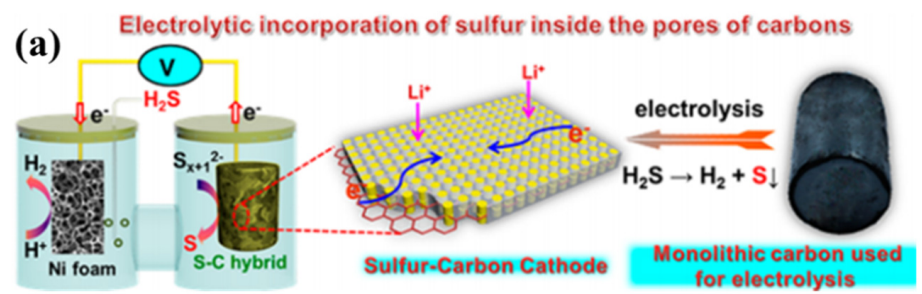

(b)

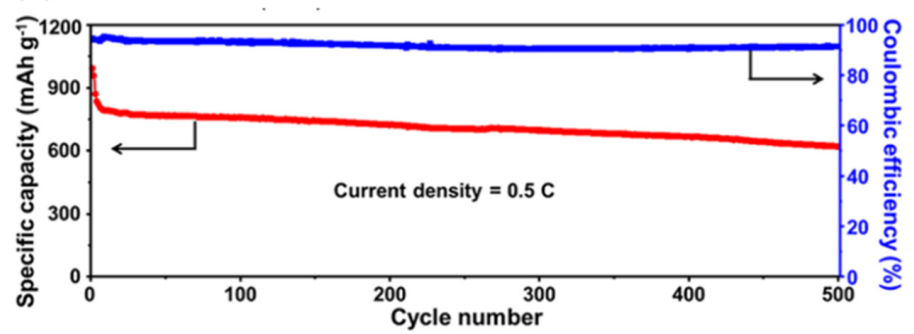

Figure 4. (a) Illustration of the electrolysis approach to the preparation of sulphur-carbon hybrids; and (b) long-term cyclability and Coulombic efficiency of monolithic carbon-2 (MLC-2) at 0.5C $\left(1 \mathrm{C}=1675 \mathrm{~mA} \cdot \mathrm{g}^{-1}\right)$ [39]. Reproduced with permission from [39]. Copyright 2016, American Chemical Society.

\subsubsection{Mesoporous Carbon-Sulphur Composites}

Mesoporous carbon is also a good candidate for accommodating the active materials. Moreover, it contributes to the achievement of high initial capacities by the better transport of solvated electrolyte and lithium ions [38]. Early work in this area was performed by Wang et al. [48], where activated carbon with a pore size of around $2.5 \mathrm{~nm}$ was used as the conductive matrix. A reversible capacity of $400 \mathrm{~mA} \cdot \mathrm{h} \cdot \mathrm{g}^{-1}$ was achieved. In 2008, Wang et al. [49] again reported mesoporous C-S composites as the cathode materials for $\mathrm{Li}-\mathrm{S}$ batteries. The $\mathrm{C}-\mathrm{S}$ composites were tested in a novel ionic liquid electrolyte consisting of 1-ethyl-3-methylimidazolium bis(trifluoromethanesulfonyl)imide and lithium bistrifluoromethanesulfonimidate. The capacity and cyclic stability of the C-S composite using the ionic liquid electrolyte were much better than the sample tested in a conventional organic solvent electrolyte [49].

In 2009, breakthroughs were made regarding mesoporous $\mathrm{C}-\mathrm{S}$ composite applications in $\mathrm{Li}-\mathrm{S}$ batteries by Nazar's group [50]. They reported CMK-3-S composites that displayed all of the benefits of confinement effects at a small length scale. The retaining conductive carbon framework at nanoscale 
dimensions afforded excellent accessibility of the active material. It not only acted as an electronic conduit to the active mass encapsulated within, but also served as a mini electrochemical reaction chamber. The entrapment ensured that a more complete redox process took place, and resulted in enhanced utilization of the active sulphur material. Figure 5a illustrates a scanning electron microscopy (SEM) image of CMK-3-S composite, and Figure 5b reveals a schematic diagram of the sulphur (yellow) confined in the interconnected pore structure of mesoporous carbon. From then on, a number of works reported the CMK-3 and CMK-3-based carbon composite as the sulphur host for Li-S batteries [51-57].
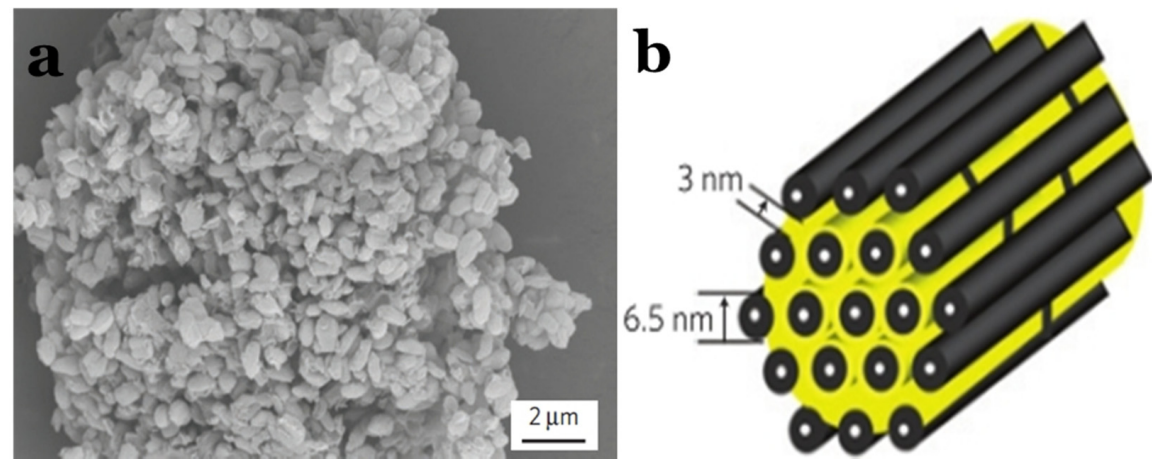

Figure 5. (a) Scanning electron microscopy (SEM) image of CMK-3-S; and (b) a schematic diagram of the sulphur (yellow) confined in the interconnected pore structure of CMK-3 [50]. Reproduced with permission from [50]. Copyright 2009, Nature Publishing Group.

To date, in addition to the mesoporous CMK-3, researchers have developed many other kinds of mesoporous carbon by using various carbon sources as the sulphur host for Li-S batteries (also displayed in Table 1) [58-75]. For instance, a mesoporous carbon sphere, where cetyltrimethyl ammonium bromide (CTAB) acted as the carbon source and mesoporous silica provided the hard template with uniform channels, was employed as the ordered conductive carbon matrix (OMCs) in the sulphur cathode for the $\mathrm{Li}-\mathrm{S}$ battery based on an all-solid-state $\mathrm{PEO}_{18} \mathrm{Li}\left(\mathrm{CF}_{3} \mathrm{SO}_{2}\right)_{2} \mathrm{~N}-10 \mathrm{wt} \% \mathrm{SiO} 2$ electrolyte [64]. S-OMCs composite showed excellent cycling performance with a reversible discharge capacity of about $800 \mathrm{~mA} \cdot \mathrm{h}^{-\mathrm{g}^{-1}}$ after 25 cycles. Bimodal mesoporous carbon (BMC) with $2.0 \mathrm{~nm}$ and $5.6 \mathrm{~nm}$ mesopores was used with the intention of regulating ion conduction in the mesoporous framework for high-rate performance of Li-S batteries [59]. The high discharge capacities and good cycling stability at a very high current rate of $1675 \mathrm{~mA} \cdot \mathrm{g}^{-1}$ can be attributed to the unique bimodal porous structure of the carbon, where the small mesopores are responsible for suppressing the diffusion of polysulphide species into the electrolyte, while the large interconnected cylindrical mesopores favour the rapid transport of solvated $\mathrm{Li}^{+}$on charge/discharge [59].

\subsubsection{Hierarchical Porous Carbon-Sulphur Composites}

Due to micropores having a stronger restrictive function on active materials (which achieves better cycling stability), and the mesopores being beneficial to the rapid ion transport, a hierarchical porous carbon (HPC) that can combine the advantages of micropores, mesopores, and even macropores in the sulphur host structure are receiving increased attention among researchers [76-78].

As early as 2008, a highly HPC was synthesized by thermally treating a mixture of polyacrylonitrile (PAN) and sodium carbonates in order to be employed as the sulphur host [79]. The S/HPC composite with $57 \mathrm{wt} \%$ sulphur delivers an initial high specific capacity up to $1155 \mathrm{~mA} \cdot \mathrm{h} \cdot \mathrm{g}^{-1}$ and a stable capacity of $745 \mathrm{~mA} \cdot \mathrm{h} \cdot \mathrm{g}^{-1}$ after 84 cycles at the current density of $40 \mathrm{~mA} \cdot \mathrm{g}^{-1}$. Later, Liang's group [80] reported a hierarchically structured sulphur-carbon nanocomposite material as the high surface-area cathode for rechargeable lithium batteries. First, the mesoporous carbon with $7.3 \mathrm{~nm}$ pores was synthesized through a soft-template synthesis method, followed by potassium hydroxide activation, resulting in a bimodal porous carbon with added microporosity of less than 
$2 \mathrm{~nm}$. Apart from the soft-template method to synthesise the HPC, researchers have developed many hard-template synthesis methods; i.e., $\mathrm{SiO}_{2}$ [81-83], $\mathrm{Mg}(\mathrm{OH})_{2}$ [84], $\mathrm{MOF}$ [37,85], etc. Recently, multi-chambered micro/mesoporous carbon nanocubes (P@CNC) as new polysulphide reservoirs have been synthesized by Wang's group [86], where they used the mesoporous $\mathrm{MnO}$ as a template, which was coated with poly(3,4-ethylenedioxythiophene) (PEDOT), followed by encapsulating sulphur to form P@CNC-S composites, as shown in Figure 6a-c. The composites demonstrated an initial reversible capacity of $1078 \mathrm{~mA} \cdot \mathrm{h} \cdot \mathrm{g}^{-1}$ at $0.5 \mathrm{C}$ rate, with a capacity retention ratio of $93.2 \%$ after 1000 cycles, as shown in Figure 6d.

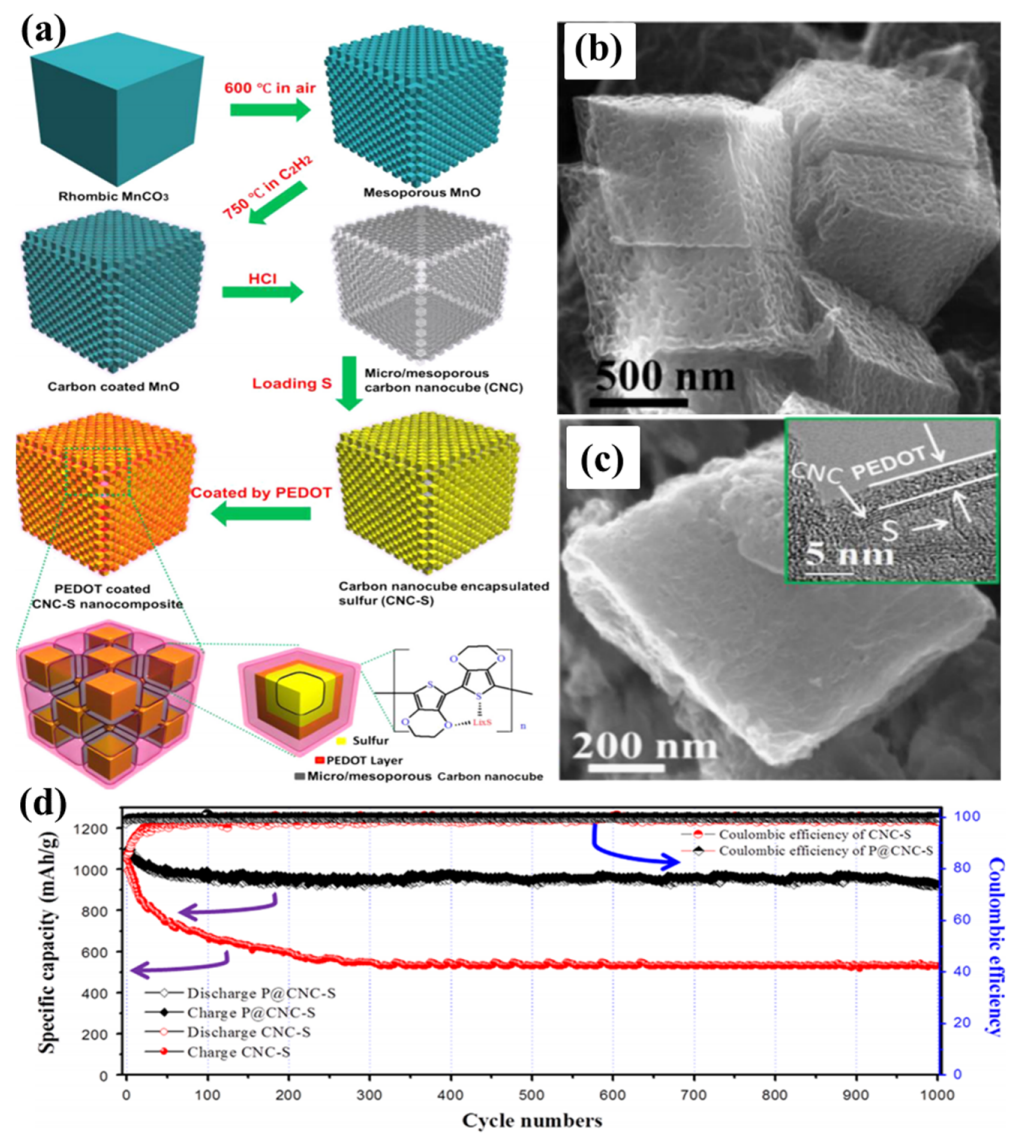

Figure 6. (a) A schematic illustration for preparing poly(3,4-ethylenedioxythiophene) (PEDOT)-coated multi-chambered micro/mesoporous carbon nanocube-sulphur composites (P@CNC-S); (b) SEM image of micro/mesoporous carbon nanocubes; (c) SEM image of P@CNC-S composites with inset high-resolution transmission electron microscopy (HRTEM) image of the details of P@CNC-S composites; (d) cycling performance of P@CNC-S and CNC-S composites at 0.5C and the corresponding Coulombic efficiencies [86]. Reproduced with permission from [86]. Copyright 2015, Elsevier.

After conducting a comprehensive summary (as displayed in Table 2), it can be concluded that micropores render better improvement in cycling performance via their unique space confinement effect, but the sulphur loading inside the micropores is very limited. Mesopores can not only further boost the sulphur loading on the electrode, but also provide good entrapment of active species (especially for the small mesopores with sizes $2-5 \mathrm{~nm}$ ) and sufficient ion transport channels for better rate capability. Macropores can function as ion-reservoirs for fast electrolyte ingress and diffusion, but risk polysulphide migration due to the possible open outlets. It is proposed that the construction of hierarchical pore architectures (i.e., the combination of micro-, meso-, and/or macro-pores) is a promising research and development direction of $\mathrm{Li}-\mathrm{S}$ batteries. 
Table 2. Electrochemical performances of various porous carbonaceous materials in Li-S batteries. PAN: polyacrylonitrile; MOF: metal organic framework; DNA: deoxyribonucleic acid; and HPC: hierarchical porous carbon.

\begin{tabular}{|c|c|c|c|c|c|}
\hline & Porous Carbon & Pore Size/BET Areas/Pore Volumes & $\begin{array}{c}\text { Sulphur } \\
\text { Content (wt\%) }\end{array}$ & $\begin{array}{l}\text { Reversible Capability } \\
\text { (at } n \text {th Cycle and C-Rate) }\end{array}$ & Reference \\
\hline \multirow{11}{*}{$\begin{array}{l}\text { Microporous } \\
\text { Carbon }\end{array}$} & Bamboo carbon & $0.6-0.75 \mathrm{~nm} / 791.80 \mathrm{~m}^{2} \cdot \mathrm{g}^{-1} / 0.38 \mathrm{~cm}^{3} \cdot \mathrm{g}^{-1}$ & 50 & $550 \mathrm{~mA} \cdot \mathrm{h} \cdot \mathrm{g}^{-1}(150 \mathrm{th}, 0.5 \mathrm{C})$ & [14] \\
\hline & MLC-2 & $0.6 \mathrm{~nm} / 576 \mathrm{~m}^{2} \cdot \mathrm{g}^{-1} /-$ & 70 & $612 \mathrm{~mA} \cdot \mathrm{h} \cdot \mathrm{g}^{-1}$ (500th, 0.5C) & [37] \\
\hline & Nitrogen-doped microporous carbons & $<2 \mathrm{~nm} / 1900 \mathrm{~m}^{2} \cdot \mathrm{g}^{-1} / 1.2 \mathrm{~cm}^{3} \cdot \mathrm{g}^{-1}$ & 40 & $1054 \mathrm{~mA} \cdot \mathrm{h} \cdot \mathrm{g}^{-1}(100 \mathrm{th}, 0.5 \mathrm{C})$ & [39] \\
\hline & Carbon FDU & $0.46 \mathrm{~nm} / 876 \mathrm{~m}^{2} \cdot \mathrm{g}^{-1} / 0.93 \mathrm{~cm}^{3} \cdot \mathrm{g}^{-1}$ & 40 & $608 \mathrm{~mA} \cdot \mathrm{h} \cdot \mathrm{g}^{-1}\left(170 \mathrm{th}, 500 \mathrm{~mA} \cdot \mathrm{g}^{-1}\right)$ & [40] \\
\hline & PAN derived carbon & $<2 \mathrm{~nm} / 738 \mathrm{~m}^{2} \cdot \mathrm{g}^{-1} /-$ & 53.7 & $740 \mathrm{~mA} \cdot \mathrm{h} \cdot \mathrm{g}^{-1}(100 \mathrm{th}, 0.05 \mathrm{C})$ & [41] \\
\hline & Micro-activated carbon & $1.87 \mathrm{~nm} / 1696 \mathrm{~m}^{2} \cdot \mathrm{g}^{-1} / 0.79 \mathrm{~cm}^{3} \cdot \mathrm{g}^{-1}$ & 54.27 & $500 \mathrm{~mA} \cdot \mathrm{h} \cdot \mathrm{g}^{-1}\left(50 \mathrm{th}, 3200 \mathrm{~mA} \cdot \mathrm{g}^{-1}\right)$ & [42] \\
\hline & Graphitic carbon & $<2 \mathrm{~nm} / 791.80 \mathrm{~m}^{2} \cdot \mathrm{g}^{-1} / 0.38 \mathrm{~cm}^{3} \cdot \mathrm{g}^{-1}$ & 88.9 & $448.6 \mathrm{~mA} \cdot \mathrm{h} \cdot \mathrm{g}^{-1}$ (200th, $\left.0.5 \mathrm{C}\right)$ & [43] \\
\hline & Microporous carbon & $0.5 \mathrm{~nm} /-/ 0.217 \mathrm{~cm}^{3} \cdot \mathrm{g}^{-1}$ & 31 & $600 \mathrm{~mA} \cdot \mathrm{h} \cdot \mathrm{g}^{-1}\left(4020 \mathrm{th}, 400 \mathrm{~mA} \cdot \mathrm{g}^{-1}\right)$ & [44] \\
\hline & Carbon spheres & $0.7 \mathrm{~nm} / 843.5 \mathrm{~m}^{2} \cdot \mathrm{g}^{-1} /-$ & 42 & $650 \mathrm{~mA} \cdot \mathrm{h} \cdot \mathrm{g}^{-1}\left(500 \mathrm{th}, 400 \mathrm{~mA} \cdot \mathrm{g}^{-1}\right)$ & [45] \\
\hline & Carbon microspheres & $1.0 \mathrm{~nm} / 915 \mathrm{~m}^{2} \cdot \mathrm{g}^{-1} / 0.46 \mathrm{~cm}^{3} \cdot \mathrm{g}^{-1}$ & 40 & $720 \mathrm{~mA} \cdot \mathrm{h} \cdot \mathrm{g}^{-1}\left(100 \mathrm{th}, 100 \mathrm{~mA} \cdot \mathrm{g}^{-1}\right)$ & [46] \\
\hline & Flower-shaped activated porous carbon & $<2 \mathrm{~nm} / 2539 \mathrm{~m}^{2} \cdot \mathrm{g}^{-1} / 1.48 \mathrm{~cm}^{3} \cdot \mathrm{g}^{-1}$ & 60 & $600 \mathrm{~mA} \cdot \mathrm{h} \cdot \mathrm{g}^{-1}\left(50 \mathrm{th}, 1600 \mathrm{~mA} \cdot \mathrm{g}^{-1}\right)$ & [47] \\
\hline \multirow{15}{*}{$\begin{array}{l}\text { Mesoporous } \\
\text { carbon }\end{array}$} & Meso-active carbon & $2.5 \mathrm{~nm} / 1080 \mathrm{~m}^{2} \cdot \mathrm{g}^{-1} /-$ & 30 & $440 \mathrm{~mA} \cdot \mathrm{h} \cdot \mathrm{g}^{-1}\left(25 \mathrm{th}, 0.3 \mathrm{~mA} \cdot \mathrm{cm}^{-2}\right)$ & [48] \\
\hline & CMK-3 & $3.3 \mathrm{~nm} / 1976 \mathrm{~m}^{2} \cdot \mathrm{g}^{-1} / 2.1 \mathrm{~cm}^{3} \cdot \mathrm{g}^{-1}$ & 70 & $\sim 800 \mathrm{~mA} \cdot \mathrm{h} \cdot \mathrm{g}^{-1}\left(20 \mathrm{th}, 168 \mathrm{~mA} \cdot \mathrm{g}^{-1}\right)$ & [49] \\
\hline & Mesoporous carbon & $12 \mathrm{~nm} / 1100 \mathrm{~m}^{2} \cdot \mathrm{g}^{-1} / 2.3 \mathrm{~cm}^{3} \cdot \mathrm{g}^{-1}$ & 70 & $\sim 500 \mathrm{~mA} \cdot \mathrm{h} \cdot \mathrm{g}^{-1}(40 \mathrm{th}, 0.2 \mathrm{C})$ & [51] \\
\hline & CMK-3 with aniline groups & $2-3 \mathrm{~nm} / 639.6 \mathrm{~m}^{2} \cdot \mathrm{g}^{-1} / 0.7 \mathrm{~cm}^{3} \cdot \mathrm{g}^{-1}$ & 42 & $920 \mathrm{~mA} \cdot \mathrm{h} \cdot \mathrm{g}^{-1}(100 \mathrm{th}, 0.2 \mathrm{C})$ & [52] \\
\hline & CMK-3 with DNA & $3.6 \mathrm{~nm} / 1117 \mathrm{~m}^{2} \cdot \mathrm{g}^{-1} / 1.37 \mathrm{~cm}^{3} \cdot \mathrm{g}^{-1}$ & 56 & $771 \mathrm{~mA} \cdot \mathrm{h} \cdot \mathrm{g}^{-1}$ (100th, 0.1C) & [53] \\
\hline & Ordered mesoporous carbon & $5.6 / 2.3 \mathrm{~nm} / 2102 \mathrm{~m}^{2} \cdot \mathrm{g}^{-1} / 2.0 \mathrm{~cm}^{3} \cdot \mathrm{g}^{-1}$ & 60 & $400 \mathrm{~mA} \cdot \mathrm{h} \cdot \mathrm{g}^{-1}$ (400th, $\left.0.5 \mathrm{C}\right)$ & [57] \\
\hline & Bimodal porous carbons & $5.6 / 2.0 \mathrm{~nm} / 2300 \mathrm{~m}^{2} \cdot \mathrm{g}^{-1} / 2.0 \mathrm{~cm}^{3} \cdot \mathrm{g}^{-1}$ & 50 & $550 \mathrm{~mA} \cdot \mathrm{h} \cdot \mathrm{g}^{-1}(100 \mathrm{th}, 1 \mathrm{C})$ & [58] \\
\hline & Tri-modal mesoporous carbon & $2.5 / 9 / 15 \mathrm{~nm} / 2371 \mathrm{~m}^{2} \cdot \mathrm{g}^{-1} / 2.85 \mathrm{~cm}^{3} \cdot \mathrm{g}^{-1}$ & 70 & $700 \mathrm{~mA} \cdot \mathrm{h} \cdot \mathrm{g}^{-1}$ (300th, $\left.0.5 \mathrm{C}\right)$ & [59] \\
\hline & Porous biomass-derived carbon & $20-30 \mathrm{~nm} / 949.85 \mathrm{~m}^{2} \cdot \mathrm{g}^{-1} / 3.14 \mathrm{~cm}^{3} \cdot \mathrm{g}^{-1}$ & 81.29 & $483 \mathrm{~mA} \cdot \mathrm{h} \cdot \mathrm{g}^{-1}(300 \mathrm{th}, 1 \mathrm{C})$ & [60] \\
\hline & Porous carbon-2 & $4 \mathrm{~nm} / 735.2 \mathrm{~m}^{2} \cdot \mathrm{g}^{-1} / 1.56 \mathrm{~cm}^{3} \cdot \mathrm{g}^{-1}$ & 58.12 & $730 \mathrm{~mA} \cdot \mathrm{h} \cdot \mathrm{g}^{-1}\left(105 \mathrm{th}, 600 \mathrm{~mA} \cdot \mathrm{g}^{-1}\right)$ & {$[61]$} \\
\hline & Mesoporous carbon & $22 \mathrm{~nm} / 1175 \mathrm{~m}^{2} \cdot \mathrm{g}^{-1} / 4.8 \mathrm{~cm}^{3} \cdot \mathrm{g}^{-1}$ & 50 & $840 \mathrm{~mA} \cdot \mathrm{h} \cdot \mathrm{g}^{-1}$ (100th, $\left.0.1 \mathrm{C}\right)$ & [62] \\
\hline & Mesoporous carbon nanospheres & $3.5 \mathrm{~nm} / 857 \mathrm{~m}^{2} \cdot \mathrm{g}^{-1} /-$ & 20 & $400 \mathrm{~mA} \cdot \mathrm{h} \cdot \mathrm{g}^{-1}(50 \mathrm{th}, 1.8 \mathrm{C})$ & [64] \\
\hline & Silica templated mesoporous carbon-20a & $19.9 \mathrm{~nm} / 974 \mathrm{~m}^{2} \cdot \mathrm{g}^{-1} / 1.96 \mathrm{~cm}^{3} \cdot \mathrm{g}^{-1}$ & 60 & $835 \mathrm{~mA} \cdot \mathrm{h} \cdot \mathrm{g}^{-1}(50 \mathrm{th}, 0.25 \mathrm{C})$ & [65] \\
\hline & Spherical ordered mesoporous carbon & $6.0 / 3.1 \mathrm{~nm} / 2445 \mathrm{~m}^{2} \cdot \mathrm{g}^{-1} / 2.32 \mathrm{~cm}^{3} \cdot \mathrm{g}^{-1}$ & 70 & $830 \mathrm{~mA} \cdot \mathrm{h} \cdot \mathrm{g}^{-1}(100 \mathrm{th}, 0.1 \mathrm{C})$ & [67] \\
\hline & Sulphur-functionalized mesoporous carbons & $5.0 \mathrm{~nm} / 1044 \mathrm{~m}^{2} \cdot \mathrm{g}^{-1} / 1.4 \mathrm{~cm}^{3} \cdot \mathrm{g}^{-1}$ & - & $\sim 300 \mathrm{~mA} \cdot \mathrm{h} \cdot \mathrm{g}^{-1}(100 \mathrm{th}, 0.1 \mathrm{C})$ & {$[68]$} \\
\hline
\end{tabular}


Table 2. Cont

\begin{tabular}{|c|c|c|c|c|c|}
\hline & Porous Carbon & Pore Size/BET Areas/Pore Volumes & $\begin{array}{c}\text { Sulphur } \\
\text { Content (wt } \%)\end{array}$ & $\begin{array}{l}\text { Reversible Capability } \\
\text { (at } n \text {th Cycle and C-Rate) }\end{array}$ & Reference \\
\hline \multirow{5}{*}{$\begin{array}{l}\text { Mesoporous } \\
\text { carbon }\end{array}$} & Porous spherical carbon & $5.16 \mathrm{~nm} / 2008.12 \mathrm{~m}^{2} \cdot \mathrm{g}^{-1} / 3.40 \mathrm{~cm}^{3} \cdot \mathrm{g}^{-1}$ & 59 & $\sim 850 \mathrm{~mA} \cdot \mathrm{h} \cdot \mathrm{g}^{-1}$ (50th, 0.1C) & [69] \\
\hline & Nitrogen-doped mesoporous carbon & $2-20 \mathrm{~nm} / 1474.97 \mathrm{~m}^{2} \cdot \mathrm{g}^{-1} / 2.08 \mathrm{~cm}^{3} \cdot \mathrm{g}^{-1}$ & 70 & $800 \mathrm{~mA} \cdot \mathrm{h} \cdot \mathrm{g}^{-1}\left(100 \mathrm{th}, 0.70 \mathrm{~mA} \cdot \mathrm{cm}^{-2}\right)$ & [70] \\
\hline & Mesoporous carbon foam & $2-10 \mathrm{~nm} / 1478.55 \mathrm{~m}^{2} \cdot \mathrm{g}^{-1} / 2.28 \mathrm{~cm}^{3} \cdot \mathrm{g}^{-1}$ & 57.22 & $878 \mathrm{~mA} \cdot \mathrm{h} \cdot \mathrm{g}^{-1}$ (50th, $\left.0.05 \mathrm{C}\right)$ & [72] \\
\hline & Layered $\mathrm{Ti}_{2} \mathrm{AlC}$-derived carbon & $3-15 \mathrm{~nm} / 1264 \mathrm{~m}^{2} \cdot \mathrm{g}^{-1} / 1.89 \mathrm{~cm}^{3} \cdot \mathrm{g}^{-1}$ & 50 & $724 \mathrm{~mA} \cdot \mathrm{h} \cdot \mathrm{g}^{-1}(200 \mathrm{th}, 0.5 \mathrm{C})$ & [73] \\
\hline & Mesoporous carbon & $10 \mathrm{~nm} / 215 \mathrm{~m}^{2} \cdot \mathrm{g}^{-1} /-$ & 36 & $836 \mathrm{~mA} \cdot \mathrm{h} \cdot \mathrm{g}^{-1}\left(100 \mathrm{th}, 230 \mathrm{~mA} \cdot \mathrm{g}^{-1}\right)$ & [74] \\
\hline \multirow{11}{*}{ HPC } & MOF-5 derived hierarchically porous carbon & $0-200 \mathrm{~nm} / 1945 \mathrm{~m}^{2} \cdot \mathrm{g}^{-1} / 1.92 \mathrm{~cm}^{3} \cdot \mathrm{g}^{-1}$ & 51 & $662.3 \mathrm{~mA} \cdot \mathrm{h} \cdot \mathrm{g}^{-1}\left(40 \mathrm{th}, 400 \mathrm{~mA} \cdot \mathrm{g}^{-1}\right)$ & [38] \\
\hline & Aspergillus flavus derived carbon & $1.5-3.5 \mathrm{~nm} / 2459.6 \mathrm{~m}^{2} \cdot \mathrm{g}^{-1} / 1.30 \mathrm{~cm}^{3} \cdot \mathrm{g}^{-1}$ & 56.7 & $800 \mathrm{~mA} \cdot \mathrm{h} \cdot \mathrm{g}^{-1}$ (120th, 0.5C) & [75] \\
\hline & Hierarchically ordered porous carbon & $9 / 300 \mathrm{~nm} / 850 \mathrm{~m}^{2} \cdot \mathrm{g}^{-1} / 1.4 \mathrm{~cm}^{3} \cdot \mathrm{g}^{-1}$ & 50 & $473.6 \mathrm{~mA} \cdot \mathrm{h} \cdot \mathrm{g}^{-1}(100 \mathrm{th}, 1 \mathrm{C})$ & [77] \\
\hline & PAN derived HPC & $0-100 \mathrm{~nm} / 1473.2 \mathrm{~m}^{2} \cdot \mathrm{g}^{-1} /-$ & 57 & $745 \mathrm{~mA} \cdot \mathrm{h} \cdot \mathrm{g}^{-1}\left(84 \mathrm{th}, 40 \mathrm{~mA} \cdot \mathrm{g}^{-1}\right)$ & [79] \\
\hline & Hierarchically porous carbon & $\begin{array}{c}<2 \mathrm{~nm}, 2-4 \mathrm{~nm}, 7.3 \mathrm{~nm} / 1566.1 \mathrm{~m}^{2} \cdot \mathrm{g}^{-1} / \\
0.503 \mathrm{~cm}^{3} \cdot \mathrm{g}^{-1} \text { (micropore volume ) }\end{array}$ & 51.5 & $\sim 350 \mathrm{~mA} \cdot \mathrm{h} \cdot \mathrm{g}^{-1}\left(50 \mathrm{th}, 2500 \mathrm{~mA} \cdot \mathrm{g}^{-1}\right)$ & [80] \\
\hline & Hierarchical porous honeycomb carbon & $0-100 \mathrm{~nm} / 614.4 \mathrm{~m}^{2} \cdot \mathrm{g}^{-1} / 1.34 \mathrm{~cm}^{3} \cdot \mathrm{g}^{-1}$ & 66.3 & $564 \mathrm{~mA} \cdot \mathrm{h} \cdot \mathrm{g}^{-1}(100 \mathrm{th}, 2 \mathrm{C})$ & [81] \\
\hline & Hierarchically porous carbon monoliths & $0-100 \mathrm{~nm} / 1426 \mathrm{~m}^{2} \cdot \mathrm{g}^{-1} / 3.097 \mathrm{~cm}^{3} \cdot \mathrm{g}^{-1}$ & 75 & $469 \mathrm{~mA} \cdot \mathrm{h} \cdot \mathrm{g}^{-1}(25 \mathrm{th},-)$ & [82] \\
\hline & $\begin{array}{l}\text { Sulphur-infiltrated porous } \\
\text { carbon microspheres }\end{array}$ & $0-100 \mathrm{~nm} / 2485 \mathrm{~m}^{2} \cdot \mathrm{g}^{-1} / 5.1 \mathrm{~cm}^{3} \cdot \mathrm{g}^{-1}$ & 60 & $904 \mathrm{~mA} \cdot \mathrm{h} \cdot \mathrm{g}^{-1}(100 \mathrm{th}, 1 \mathrm{C})$ & [83] \\
\hline & $\begin{array}{l}\mathrm{Mg}(\mathrm{OH})_{2} \text { templated-hierarchically } \\
\text { porous carbon }\end{array}$ & $0-100 \mathrm{~nm} / 902.5 \mathrm{~m}^{2} \cdot \mathrm{g}^{-1} / 2.60 \mathrm{~cm}^{3} \cdot \mathrm{g}^{-1}$ & 84 & $562 \mathrm{~mA} \cdot \mathrm{h} \cdot \mathrm{g}^{-1}(100 \mathrm{th}, 1 \mathrm{C})$ & [84] \\
\hline & Hierarchically pore-structured carbon pillars & $0-25 \mathrm{~nm} / 951 \mathrm{~m}^{2} \cdot \mathrm{g}^{-1} / 0.484 \mathrm{~cm}^{3} \cdot \mathrm{g}^{-1}$ & 58 & $456 \mathrm{~mA} \cdot \mathrm{h} \cdot \mathrm{g}^{-1}$ (40th, $\left.0.1 \mathrm{C}\right)$ & [85] \\
\hline & $\begin{array}{l}\text { Multi-chambered micro/ } \\
\text { mesoporous carbon nanocubes }\end{array}$ & $0-90 \mathrm{~nm} / 2425 \mathrm{~m}^{2} \cdot \mathrm{g}^{-1} / 3.72 \mathrm{~cm}^{3} \cdot \mathrm{g}^{-1}$ & 72 & $530 \mathrm{~mA} \cdot \mathrm{h} \cdot \mathrm{g}^{-1}(1000 \mathrm{th}, 5 \mathrm{C})$ & [86] \\
\hline
\end{tabular}




\subsubsection{Hollow Carbon-Sulphur Composites}

Several advantages of hollow carbon hosts were suggested: (1) maximizing the amount of sulphur sequestered by the capsules; (2) minimizing polysulphide dissolution and shuttling; (3) preserving fast transport of lithium ions; and (4) good conductivity [78]. Because of these attributes, various kinds of the hollow C-S composites have been synthesized [9,87-95].

Jayaprakash et al. [9] used petroleum pitch as carbon precursor and porous silica as template to synthesize mesoporous carbon hollow spheres. Sulphur was incorporated into these mesoporous carbon hollow spheres, and the resulting $\mathrm{C}-\mathrm{S}$ composites possessed an initial specific discharge capacity of $1071 \mathrm{~mA} \cdot \mathrm{h} \cdot \mathrm{g}^{-1}$ and maintained a reversible capacity of $974 \mathrm{~mA} \cdot \mathrm{h} \cdot \mathrm{g}^{-1}$ (at a rate of $0.5 \mathrm{C}$ ) with $91 \%$ capacity retention after 100 cycles.

Complex double-shelled hollow carbon spheres were synthesized using hollow $\mathrm{SnO}_{2}$ spheres as a template, as shown in Figure 7a [90]. Glucose was uniformly coated on the interior and exterior surfaces of the template, and then the complex hollow carbon was derived from the template. The double-shelled structure was designed to host higher amounts of sulphur, suppress the outward diffusion of dissolved polysulphides, and buffer the volume change upon cycling. A satisfactory capacity of around $500 \mathrm{~mA} \cdot \mathrm{h} \cdot \mathrm{g}^{-1}$ was obtained at a current density of $850 \mathrm{~mA} \cdot \mathrm{g}^{-1}$.

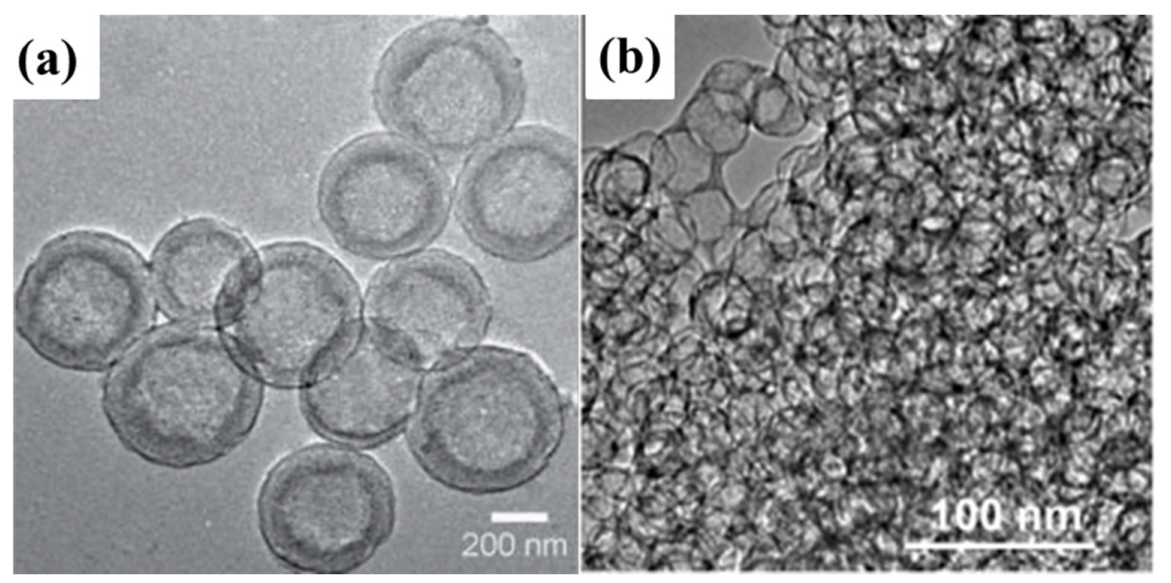

Figure 7. (a) Transmission electron microscopy (TEM) images of mesoporous carbon hollow spheres [90]. Reproduced with permission from [90], Copyright 2012, Wiley-VCH. (b) Peapod-like mesoporous carbon [93]. Reproduced with permission from [93]. Copyright 2013, American Chemical Society.

Peapod-like mesoporous carbon with interconnected pore channels and large pore volume $\left(4.69 \mathrm{~cm}^{3} \cdot \mathrm{g}^{-1}\right)$ as shown in Figure $7 \mathrm{~b}$ was synthesized and used as the matrix to fabricate C-S composite which served as attractive cathodes for Li-S batteries [93]. Systematic investigation of the $\mathrm{C}-\mathrm{S}$ composites reveals that the carbon matrix can hold a high but suitable sulphur loading of $84 \mathrm{wt} \%$, and such controllable sulphur-filling also effectively allows the volume expansion of active sulphur during $\mathrm{Li}^{+}$insertion. Moreover, the thin carbon walls $(3-4 \mathrm{~nm})$ of carbon matrix are not only able to shorten the pathway of $\mathrm{Li}^{+}$transfer and conduct electrons to overcome the poor kinetics of sulphur cathode, but are also flexible to warrant structure stability.

\subsubsection{Biochar-Sulphur Composites}

Being simple, sustainable, scalable, and environmentally friendly, a diverse range of biomasses with hierarchical structures have provided a number of sustainable templates for the synthesis of functional nanostructured carbon materials $[14,96]$, which have been attracting enthusiastic attention for application in $\mathrm{Li}-\mathrm{S}$ batteries.

As a source for these biomasses, waste animal tissues are widely used. In 2011, pig bone-derived carbon with a unique hierarchical porous structure was prepared by $\mathrm{KOH}$ activation [97]. The pig 
bone-derived HPC-S composites have been tested as a novel cathode for Li-S batteries, and a high initial capacity of $1265 \mathrm{~mA} \cdot \mathrm{h} \cdot \mathrm{g}^{-1}$ and $643 \mathrm{~mA} \cdot \mathrm{h} \cdot \mathrm{g}^{-1}$ after 50 cycles was obtained. Later, Cui's group [96] reported that crab shells can be used as biotemplates to fabricate hollow carbon nanofibers (CNFs) and then be used to encapsulate sulphur due to its unique Bouligand structure consisting of highly mineralized chitin-protein fibers as shown in Figure 8a,b. The cycling performance is shown in Figure $8 \mathrm{c}$. At a C/5 rate, an initial capacity of $1230 \mathrm{~mA} \cdot \mathrm{h} \cdot \mathrm{g}^{-1}$ was obtained, indicating $73 \%$ sulphur utilization during the first discharge process. After 200 cycles, a reversible capacity of around $810 \mathrm{~mA} \cdot \mathrm{h} \cdot \mathrm{g}^{-1}$ was still retained, corresponding to a capacity retention of $65 \%$. Moreover, silk [98], fish scales [99], eggshells [100], among others were also employed to synthesise the biochar-sulphur composites as novel cathodes in Li-S batteries.

\section{(a)}
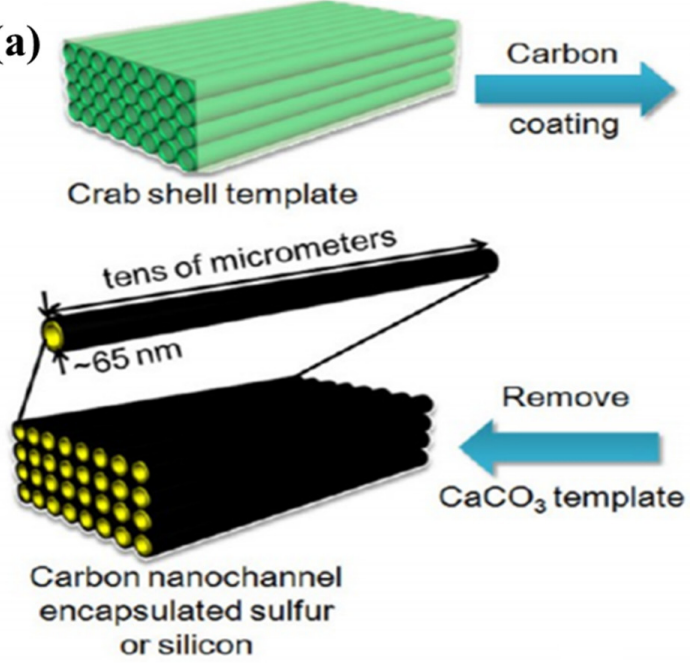

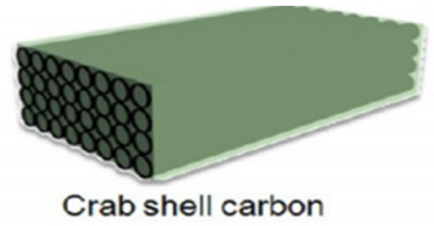

Crab shell carbon

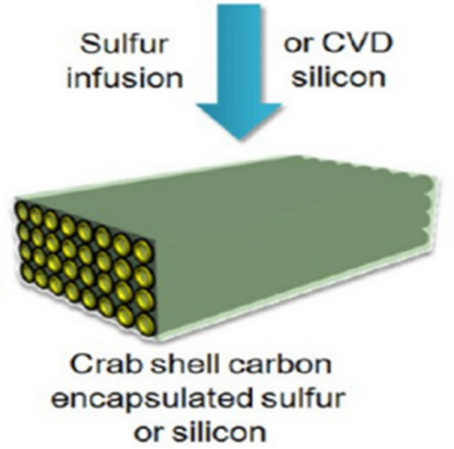

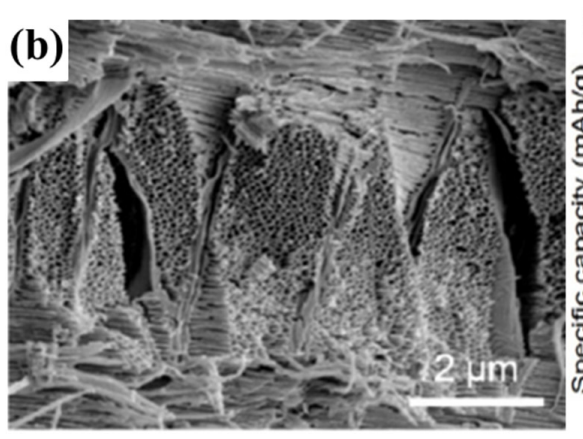

(c)

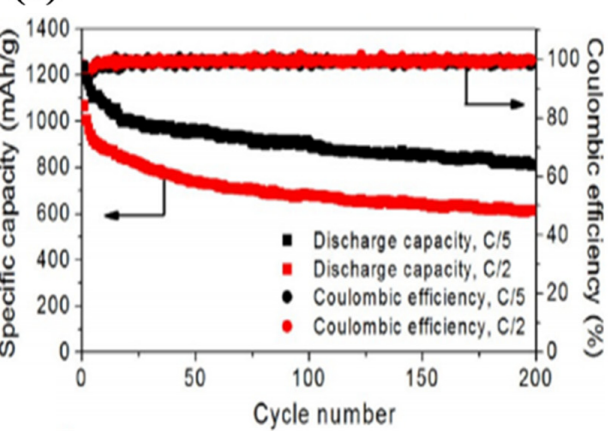

Figure 8. (a) Schematic illustration of the fabrication procedure for hollow CNF arrays encapsulating sulphur or silicon electrode materials based on stone crab shell templates; (b) SEM image of crab shell; and (c) capacity and Coulombic efficiency at C/5 and C/2 vs. cycle number [96]. Reproduced with permission from [96]. Copyright 2013, American Chemical Society. CVD: chemical vapor deposition.

Plant tissue has also proven to be a good source of porous carbon. For example, kapok fiber-derived carbon nanotiles (KFCNTs) were used as the host of sulphur to construct KFCNTs/S cathodes for Li-S batteries [101]. KFCNTs-with scale-like microstructure-are important for retarding the shuttling of soluble polysulphides, rendering $S$ particles electrically conducting, and accommodating volume variation of $\mathrm{S}$ during the $\mathrm{Li}^{+}$insertion/extraction upon cycling. Owing to their unique microstructure, the resulting KFCNTs/S (93.2 $\mathrm{wt} \%$ ), electrodes exhibited a high and stable volumetric capacity of $504 \mathrm{~mA} \cdot \mathrm{h} \cdot \mathrm{cm}^{-3}$ (calculated from the whole electrode, the corresponding gravimetric capacity is $524 \mathrm{~mA} \cdot \mathrm{h} \cdot \mathrm{g}^{-1}$ ), with a superior capacity retention up to $95.4 \%$ after 90 cycles at $0.4 \mathrm{~A} \cdot \mathrm{g}^{-1}$. In 2014, our group [14] used $\mathrm{KOH}$-activated bamboo biochar as the sulphur host for 
Li-S batteries. The as-prepared microporous bamboo-sulphur with $50 \mathrm{wt} \%$ sulphur content delivered a high initial capacity of $1295 \mathrm{~mA} \cdot \mathrm{h} \cdot \mathrm{g}^{-1}$ at a low discharge rate of $160 \mathrm{~mA} \cdot \mathrm{g}^{-1}$ and high capacity retention of $550 \mathrm{~mA} \cdot \mathrm{h} \cdot \mathrm{g}^{-1}$ after 150 cycles at a high discharge rate of $800 \mathrm{~mA} \cdot \mathrm{g}^{-1}$, with excellent Coulombic efficiency ( $\geq 95 \%$ ). In addition, some other plant tissues (i.e., poplar catkin [102], pomelo peel [11], and lotus leaves [103]) have also been carbonized in order to mix with sulphur to form biomass $\mathrm{C}-\mathrm{S}$ composites as environmentally friendly, sustainable cathodes in $\mathrm{Li}-\mathrm{S}$ batteries.

In addition to animal and plant tissue-sourced biochar, low-cost plant extracts, such as cellulose and glucose, are also good candidates for the synthesis of biochar-sulphur composites. Recently, a nitrogen and sulphur dual-doped carbon (NSC) derived from polyrhodanine@cellulose for advanced Li-S batteries has been reported by Nazar and her co-workers [104]. The as-prepared NSC/S-70 electrode exhibited a high discharge capacity of $1280 \mathrm{~mA} \cdot \mathrm{h} \cdot \mathrm{g}^{-1}$ and $830 \mathrm{~mA} \cdot \mathrm{h} \cdot \mathrm{g}^{-1}$ at $\mathrm{C} / 5$ and $2 \mathrm{C}$ rates, respectively. At C/5, the capacity of NSC/S-70 stabilized at $1080 \mathrm{~mA} \cdot \mathrm{h} \cdot \mathrm{g}^{-1}$ at 100 cycles. Meanwhile, Fellinger's group [105] reported an ionothermal sol-gel strategy to synthesize hierarchically porous carbon aerogels doped with different heteroatoms by using biomass precursors (glucose, glucosamine, glucose + cellulose triacetate (TCA), or glucosamine + TCA) in a scalable process. Morphologically similar but chemically different materials are used to study the influence of heteroatoms in $\mathrm{Li}-\mathrm{S}$ batteries.

\subsection{One-Dimensional Carbon Nanostructure/Sulphur Electrodes}

Residual sulphur particles with sizes in the range of microns usually remain within the electrode framework without being encapsulated in pores. The formation of pores in the electrode and inhomogeneous precipitation of lithium sulphide can result in lower active material utilization as cycling proceeds, while the conductive matrix created by the one-dimensional (1D) carbon structural network provides better electrical connection to the active materials and a better encapsulation effect for sulphur due to their 1D structure.

\subsubsection{Carbon Nanofiber-Sulphur Composites}

Initially, carbon nanofiber (CNF) was used as an additive in the sulphur electrode in order to improve cycling properties [106,107]. In 2011, Elazari et al. [108] synthesized CNF-S composites by impregnating microporous activated carbon fibers with elemental melted sulphur, and Ji et al. [109] encapsulated sulphur in porous CNFs via electrospinning, carbonization, and solution-based chemical reaction-deposition method. The CNF-S composites prepared by two distinctive methods as cathodes for Li-S batteries were both evaluated, and demonstrated good electrochemical performances. Both of them attributed the good electrochemical performance to the high electrical conductivity and the extremely high surface area of the CNFs that homogeneously disperse and immobilize $\mathrm{S}$ on their porous structures, alleviating the polysulphide shuttle phenomenon. Following this line of research, Cui's group [110] used anodic aluminum oxide (AAO) as the template to synthesize hollow CNFs with a high aspect ratio. Sulphur was then loaded into the hollow CNFs by mixing and heating to $155^{\circ} \mathrm{C}$. The schematic diagram of the high aspect ratio 1D hollow CNF-S composite is shown in Figure 9a. The presence of the AAO membrane prevents the coating of sulphur onto the outer walls of the CNFs, thus reducing the exposure of sulphur to the electrolyte (Figure 9b). Electrochemical testing showed that this sulphur cathode delivered a high initial discharge capacity of around $1400 \mathrm{~mA} \cdot \mathrm{h} \cdot \mathrm{g}^{-1}$ with around $75 \%$ sulphur loading in the electrode and $1 \mathrm{mg} \cdot \mathrm{cm}^{-2}$ of sulphur content. The cycling capacity retention also showed significant improvement, with a reversible capacity of around $730 \mathrm{~mA} \cdot \mathrm{h} \cdot \mathrm{g}^{-1}$ after 150 cycles of charge-discharge (Figure 9c). Recently, they found that, by introducing amphiphilic polymers to modify the CNF surface that renders strong interactions between the nonpolar carbon and the polar $\mathrm{Li}_{x} \mathrm{~S}$ clusters, the capacity fading mechanism can be reduced further [111]. The modified sulphur cathode showed excellent cycling performance with specific capacity close to $1180 \mathrm{~mA} \cdot \mathrm{h} \cdot \mathrm{g}^{-1}$ at $\mathrm{C} / 5$ current rate. Capacity retention of $80 \%$ was achieved over 300 cycles at $\mathrm{C} / 2$. 
a

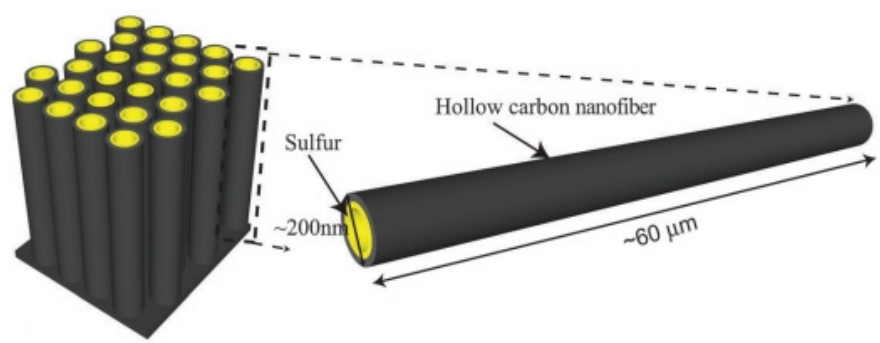

b

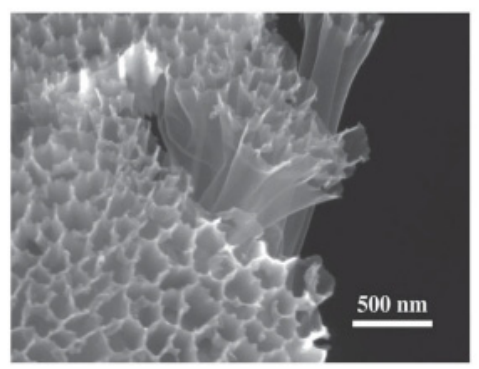

C

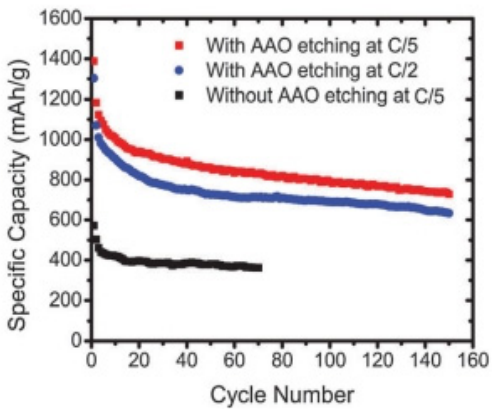

Figure 9. (a) Schematic diagram of the high aspect ratio one-dimensional (1D) hollow CNF-S composite; (b) SEM image of the cathode after sulphur infusion and anodic aluminum oxide (AAO) etching; and (c) cycling performance of the sulphur cathode at $\mathrm{C} / 5$ and $\mathrm{C} / 2$. The black curve shows cycling performance of the sulphur cathode without AAO etching [110]. Reproduced with permission from [110]. Copyright 2011, American Chemical Society.

A C-S composite based on vapor-grown carbon fiber (VGCF) was synthesized for Li-S batteries by $\mathrm{KOH}$ activation and melt-diffusion strategy in 2013 by Deng et al. [112]. It was found that the S-VGCF treated by $\mathrm{KOH}$ activation (S-aVGCF) cathode exhibited better electrochemical reversibility, higher active material utilization, and less severe polysulphide shuttle than both a pristine sulphur cathode and an S-raw VGCF composite cathode. More recently, porous CNFs as sulphur hosts for Li-S batteries were prepared by carbonized polymers, such as PAN and polypyrrole $[113,114]$.

\subsubsection{Carbon Nanotube-Sulphur Composites}

Like CNFs, carbon nanotubes (CNTs) were first used as an inactive additive material for elemental sulphur positive electrodes for Li-S rechargeable batteries [115]. Following this, the multi-walled carbon nanotubes-sulphur (MWCNTs-S) nanocomposite was prepared by heating a mixture of sublimed S and MWCNTs in certain conditions by Zhang et al. [116]. In addition, S-coated-MWCNTs prepared through capillarity action between the $S$ and MWCNTs could maintain a reversible capacity of $670 \mathrm{~mA} \cdot \mathrm{h} \cdot \mathrm{g}^{-1}$ after 60 cycles, showing a greatly enhanced cyclability when compared with the sulphur cathode prepared by simple MWCNTs addition [117]. However, it proved difficult to homogenously disperse the sulphur through the carbon by simply heating the $S$ and CNTs, resulting in low sulphur utilization and poor cyclicability of the battery. Therefore, a new method of synthesizing a high performance MWCNTs-S composite cathode material for Li-S battery by solvent exchange was realised [118]. The synthesis process was as follows: the acid-treated MWCNTs were dispersed into

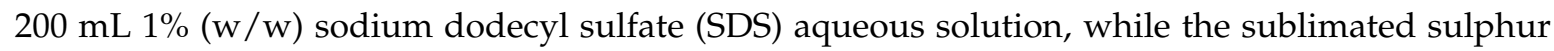
was dissolved into purified tetrahydrofuran (THF) to get a saturated solution. After that, $30 \mathrm{~mL}$ saturated solution (nearly $0.16 \mathrm{~mol} \cdot \mathrm{L}^{-1}$ ) was added into the solution containing modified MWCNTs and SDS under continuous strong stirring. After separating the suspension and washing with distilled water three times, the MWCNTs-S composite with $60 \%$ sulphur content was collected. From then on, researchers realized that the sulphur precipitating in solution can be dispersed homogeneously within 
$\mathrm{CNTs}$, which triggered a number of works about the direct-precipitation method to synthesise CNTs-S composites as the cathode material for Li-S batteries [119-123].

Aligned CNTs-S composite cathodes with high sulphur loading (90\%) were investigated by Cheng et al. [124]. The ultra-high loading amount of sulphur was attributed to the open, ordered, straight pore structure of aligned CNTa scaffolds for the uniform distribution of fine sulphur particles. The high sulphur-loaded composite yielded a high tap density with $1116.0 \mathrm{~mA} \cdot \mathrm{h} \cdot \mathrm{cm}^{-3}$.

The coating of an ultrathin sulphur nanolayer on a prepared CNTs film through a simple two-step heating process was developed by Jin et al. [125]. The CNTs-S composite film with an areal density of $\sim 5 \mathrm{mg} \cdot \mathrm{cm}^{-2}$ had a high sulphur content of $65 \mathrm{wt} \%$, which delivered an initial capacity of $1100 \mathrm{~mA} \cdot \mathrm{h} \cdot \mathrm{g}^{-1}$ and can retain a reversible capacity of $740 \mathrm{~mA} \cdot \mathrm{h} \cdot \mathrm{g}^{-1}$ after 100 charge/discharge cycles at $0.1 \mathrm{C}$. Recently, Kim's group [126] developed a strategy to encapsulate monoclinic sulphur into CNTs, wherein platinum was sputtered on the bottom side to seal the pores and function as a current collector (as shown in Figure 10a), followed by a heat treatment at $400{ }^{\circ} \mathrm{C}$. The electrode design, in conjunction with the monoclinic crystal structure, resulted in excellent electrical performance: a specific capacity reaching the theoretical value and substantial capacity retention over 1000 cycles, as shown in Figure $1 \mathrm{~d}$. Furthermore, these battery performances were achieved under the highest sulphur content to date: $\sim 81 \mathrm{wt} \%$ in the active material.
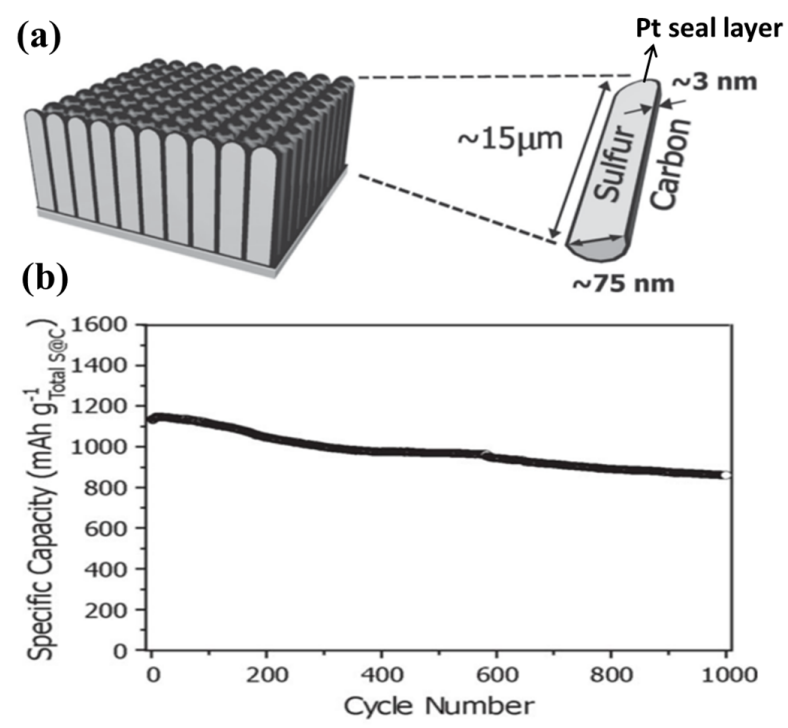

Figure 10. (a) A schematic of each CNTs-S with the dimensions of the key components denoted; and (b) cycling performance of the CNTs-S electrode with a discharge rate of 5C and a charge rate of $2 \mathrm{C}$ for 1000 cycles [126]. Reproduced with permission from [126]. Copyright 2013, WILEY-VCH.

The energy density of a battery is an important indicator for industrialization. By cutting down or eliminating the amount of binder used during the synthesis of electrodes, energy densities of cells could be significantly enhanced. CNTs-due to their unique 1D structure-can be easily used to fabricate free-standing electrodes loaded with S. In 2012, Hagen et al. [127] proposed a new type of Li-S cathode (vertically-aligned CNTs grown on a nickel foil without any binder), in which the sulphur content could reach as high as $90 \mathrm{wt} \%$. Kaskel et al. [128] reported binder-free vertically aligned (VA) $\mathrm{CNTs}-\mathrm{S}$ composite electrodes with high sulphur loadings up to $70 \mathrm{wt} \%$, where its discharge capacity could exceed $800 \mathrm{~mA} \cdot \mathrm{h} \cdot \mathrm{g}^{-1}$ according to the electrode.

In order to further reduce the amount of exposed $S$ in the CNTs-S composites, many approaches-including coating cathodes with a barrier layer [129-131], forming three-dimensional (3D) hybrid nanostructures [132-137], and producing pores to form hierarchical architectures [138-140] - were developed in order to improve the electrochemical performances for $\mathrm{Li}-\mathrm{S}$ batteries. Table 3 compares the electrochemical performances of various CNTs-S composites. 
Table 3. Electrochemical performances of various CNTs composites in Li-S batteries. MWCNTs-S: multi-walled carbon nanotubes-sulphur composite; KB: Ketjen black; VA: vertically aligned; PD: polydopamine; PAA: poly acrylic acid; RGO: reduced graphene oxide; GS: graphene sheets; VGCF: vapor-grown carbon fiber; and PNCNTs: porous nitrogen-doped carbon nanotubes.

\begin{tabular}{|c|c|c|c|}
\hline Composite Name & $\begin{array}{l}\text { Sulphur Content in } \\
\text { the Composite (wt } \%)\end{array}$ & $\begin{array}{c}\text { Reversible Capability } \\
\text { (at } n \text {th Cycle and C-Rate) }\end{array}$ & Reference \\
\hline MWCNTs-S & - & $\sim 500 \mathrm{~mA} \cdot \mathrm{h} \cdot \mathrm{g}^{-1}\left(60 \mathrm{th}, 2 \mathrm{~mA} \cdot \mathrm{cm}^{-2}\right)$ & [116] \\
\hline S-coated-MWCNTs & 68 & $\sim 650 \mathrm{~mA} \cdot \mathrm{h} \cdot \mathrm{g}^{-1}\left(60 \mathrm{th}, 100 \mathrm{~mA} \cdot \mathrm{g}^{-1}\right)$ & [117] \\
\hline Nano-S/MWCNTs & 60 & $810 \mathrm{~mA} \cdot \mathrm{h} \cdot \mathrm{g}^{-1}\left(30 \mathrm{th}, 300 \mathrm{~mA} \cdot \mathrm{g}^{-1}\right)$ & [118] \\
\hline S-MWCNTs & 75 & $854 \mathrm{~mA} \cdot \mathrm{h} \cdot \mathrm{g}^{-1}\left(30 \mathrm{th}, 100 \mathrm{~mA} \cdot \mathrm{g}^{-1}\right)$ & [119] \\
\hline Precipitated S/MWCNTs & 58.3 & $800 \mathrm{~mA} \cdot \mathrm{h} \cdot \mathrm{g}^{-1}$ (50th, 0.05C) & [120] \\
\hline S-impregnated disordered CNTs & 40 & $\sim 750 \mathrm{~mA} \cdot \mathrm{h} \cdot \mathrm{g}^{-1}$ (100th, 0.25C) & [121] \\
\hline MWCNTs-S & 75 & $592 \mathrm{~mA} \cdot \mathrm{h} \cdot \mathrm{g}^{-1}\left(50 \mathrm{th}, 200 \mathrm{~mA} \cdot \mathrm{g}^{-1}\right)$ & [122] \\
\hline S-MWCNTs/KB & 85 & $420 \mathrm{~mA} \cdot \mathrm{h} \cdot \mathrm{g}^{-1}(100 \mathrm{th}, 1 \mathrm{C})$ & [123] \\
\hline Aligned CNTs/S & 90 & $\sim 650 \mathrm{~mA} \cdot \mathrm{h} \cdot \mathrm{cm}^{-3}(90 \mathrm{th}, 0.1 \mathrm{C})$ & [124] \\
\hline S-CNTs & 65 & $740 \mathrm{~mA} \cdot \mathrm{h} \cdot \mathrm{g}^{-1}(100 \mathrm{th}, 0.1 \mathrm{C})$ & [125] \\
\hline CNTs-S & $\sim 81$ & $863 \mathrm{~mA} \cdot \mathrm{h} \cdot \mathrm{g}^{-1}(1000 \mathrm{th}, 5 \mathrm{C})$ & [126] \\
\hline CNTs-S & 90 & $600 \mathrm{~mA} \cdot \mathrm{h} \cdot \mathrm{g}^{-1}$ (19th, 0.02C) & [127] \\
\hline VA-CNTs/S & 70 & $\sim 800 \mathrm{~mA} \cdot \mathrm{h} \cdot \mathrm{g}^{-1}(40 \mathrm{th}, 0.08 \mathrm{C})$ & [128] \\
\hline S-coated CNTs & 40 & $\sim 400 \mathrm{~mA} \cdot \mathrm{h} \cdot \mathrm{g}^{-1}$ (100th, 0.1C) & [129] \\
\hline $\begin{array}{c}\text { PD-coated } \\
\text { S-MWCNTs-COOH-PAA }\end{array}$ & 83 & $640 \mathrm{~mA} \cdot \mathrm{h} \cdot \mathrm{g}^{-1}\left(500 \mathrm{th}, 1000 \mathrm{~mA} \cdot \mathrm{g}^{-1}\right)$ & [130] \\
\hline PAN-S@MWCNTs & 30 & $530 \mathrm{~mA} \cdot \mathrm{h} \cdot \mathrm{g}^{-1}(50 \mathrm{th}, 1 \mathrm{C})$ & [131] \\
\hline MWCNTs@Meso-C/S & 58.27 & $540 \mathrm{~mA} \cdot \mathrm{h} \cdot \mathrm{g}^{-1}$ (50th, $\left.0.5 \mathrm{C}\right)$ & [132] \\
\hline GS-MWCNTs@S & 70 & $844 \mathrm{~mA} \cdot \mathrm{h} \cdot \mathrm{g}^{-1}(100 \mathrm{th}, 0.2 \mathrm{C})$ & [133] \\
\hline VGCFs-S-MWCNTs & - & $716 \mathrm{~mA} \cdot \mathrm{h} \cdot \mathrm{g}^{-1}\left(40 \mathrm{th}, 335 \mathrm{~mA} \cdot \mathrm{g}^{-1}\right)$ & [134] \\
\hline MWCNTs-S-PAN & 35.1 & $491.5 \mathrm{~mA} \cdot \mathrm{h} \cdot \mathrm{g}^{-1}(100 \mathrm{th}, 0.5 \mathrm{C})$ & [135] \\
\hline RGO@MWCNTs-W/S & 68.9 & $891.5 \mathrm{~mA} \cdot \mathrm{h} \cdot \mathrm{g}^{-1}(200 \mathrm{th}, 1 \mathrm{C})$ & [136] \\
\hline Mesoporous carbon-CNTs-S & 75 & $740 \mathrm{~mA} \cdot \mathrm{h} \cdot \mathrm{g}^{-1}\left(50 \mathrm{th}, 0.84 \mathrm{~mA} \cdot \mathrm{cm}^{-2}\right)$ & [137] \\
\hline S/MWCNTs nanomicrosphere & 57 & $780 \mathrm{~mA} \cdot \mathrm{h} \cdot \mathrm{g}^{-1}\left(200 \mathrm{th}, 1000 \mathrm{~mA} \cdot \mathrm{g}^{-1}\right)$ & [138] \\
\hline $\begin{array}{c}\text { Hierarchical CNTs@S } \\
\text { coaxial nanocables }\end{array}$ & 50 & $713 \mathrm{~mA} \cdot \mathrm{h} \cdot \mathrm{g}^{-1}(150 \mathrm{th}, 1 \mathrm{C})$ & [139] \\
\hline S/PNCNTs & - & $933 \mathrm{~mA} \cdot \mathrm{h} \cdot \mathrm{g}^{-1}(50 \mathrm{th}, 1 \mathrm{C})$ & {$[140]$} \\
\hline
\end{tabular}

\subsection{Two-Dimensional Carbon Nanostructure/Sulphur Electrodes}

Graphene oxide (GO), reduced graphene oxide (RGO), and graphene are classified as two-dimensional carbon due to their ultrathin sheet structure, which contributes to them demonstrating many advantages-i.e., light weight, good flexibility, outstanding mechanical strength, and superior conductivity $[4,141]$. Therefore, they have been widely applied in electronics, optics, engineering, and are also considered as an excellent host for loading active materials for energy storage and conversion [141]. When used in Li-S batteries, they can not only enhance the conductivity of the cathode, but also accommodate the volume expansion of the sulphur electrode during the charge/discharge process. Thus, there are many works focusing on the fabrication and evaluation of the electrochemical performances of $\mathrm{GO} / \mathrm{RGO} /$ graphene-sulphur composites as the cathode for Li-S batteries.

\subsubsection{Graphene Oxide-Sulphur Composite Cathodes}

GO was first applied as a sulphur immobilizer in 2011 [142]. The researchers employed the chemical reaction-deposition strategy to deposit the $\mathrm{S}$ on the GO, and the as-prepared GO-S composites showed good cycling stability at low charge/discharge current $(0.1 \mathrm{C})$. In order to better confine 
the sulphur and accommodate the volume expansion of the sulphur as it is reduced to $\mathrm{Li}_{2} \mathrm{~S}$, the core-shell structure of sulphur@graphene oxide (S@GO) has been developed. For example, both and Huang and Meng's group [143,144] prepared core-shell S@GO by the self-assembly of S particles stabilized by a cationic surfactant and anionic GO nanosheets through electrostatic interaction; Zhou's group [145] reported a strategy of coating GO uniformly on S particles by engineering the ionic strength in various aqueous solutions. Additionally, sulphur (which possesses unique nanostructures), when combined with GO, will contribute to higher electrochemical performances. The GO-wrapped bowl-like sulphur composite (GO-BS, shown in Figure 11a,b) with an internal void space was used as cathode material of Li-S batteries [146], and realized the protection of active material and tolerance of volumetric expansion. The cycling performance of the battery made from GO-BS at $0.2 \mathrm{~A} \cdot \mathrm{g}^{-1}$ showed a discharge specific capacity of $507 \mathrm{~mA} \cdot \mathrm{h} \cdot \mathrm{g}^{-1}$ after $300 \mathrm{cycles}$, as shown in Figure 11c. The hollow/solid and sub-micron-sized sulphur sphere (Figure 11d,e) were fabricated by adjusting the amount of polyvinylpyrrolidone (PVP) in the reaction system [147]. The hollow S@GO (HS@GO) core-shell composite showed much better cycling performances than that of solid S@GO core-shell composite, as shown in Figure 11f.
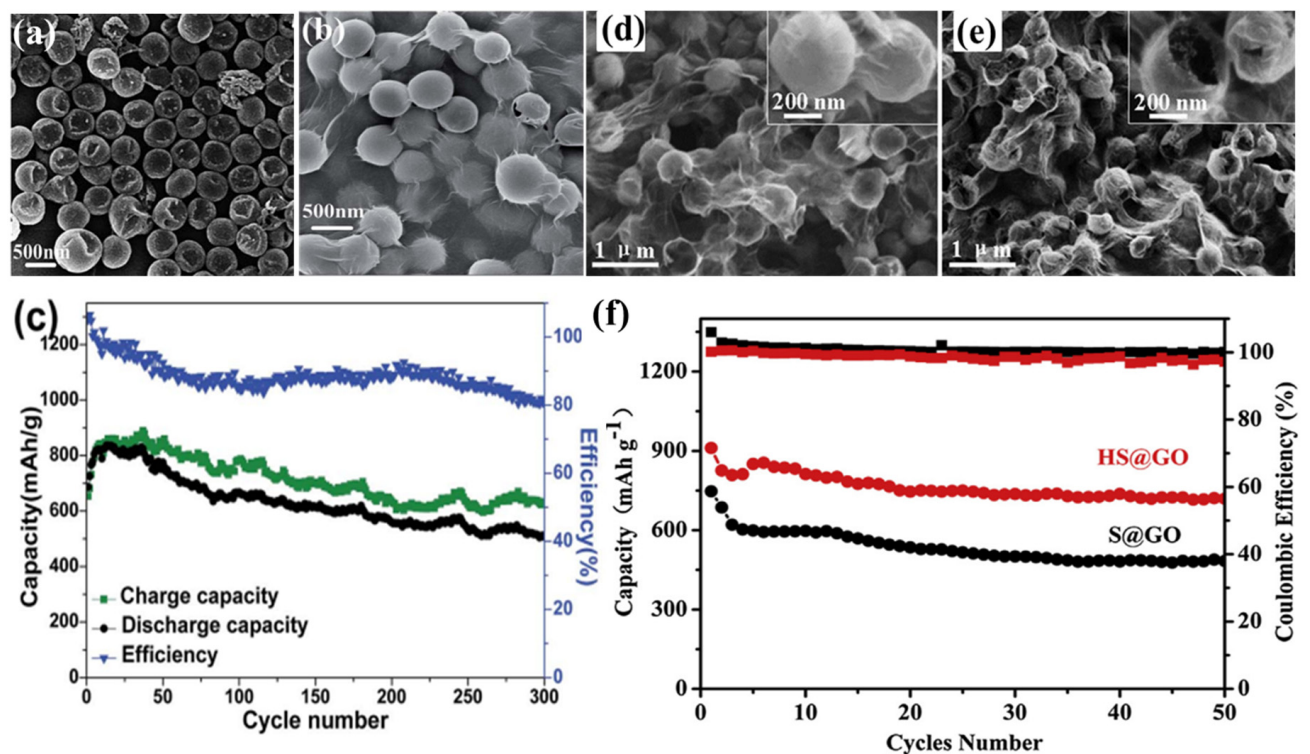

Figure 11. SEM images of (a) sulphur particles; (b) graphene oxide (GO)-wrapped bowl-like sulphur composite; and (c) Cycling performance at rates of $0.2 \mathrm{~A} \cdot \mathrm{g}^{-1}$ [146]; reproduced with permission from [146]. Copyright 2015, Royal Society of Chemistry. Field emission SEM (FESEM) images of (d) GO-coated solid and (e) hollow sulphur particles, the insert at the right-top corners are their magnification; (f) cycle performances and corresponding Coulombic efficiencies of sulphur@graphene oxide (S@GO) and hollow S@GO (HS@GO) electrodes at 0.2C [147]. Reproduced with permission from [147]. Copyright 2015, Elsevier.

\subsubsection{Graphene/Reduced Graphene Oxide-Sulphur Composite Cathodes}

When GO is reduced, its conductivity increases significantly. Therefore, the RGO-S or graphene-S composites should illustrate better electrochemical performances compared to the relative GO-S cathodes. To date, there have been a large amount of reports wherein RGO-S composites are utilized as the cathodes for Li-S batteries.

As early as 2011, researchers began using the hydrothermal method to reduce GO to RGO, in order to be mixed with sulphur to fabricate RGO-S composites [148]. However, the sulphur content is only $17.6 \%$ across whole electrode, which fails to meet the demands of the industry. Later, Dong's group [149] also used the hydrothermal method to reduce GO, but the team managed to increase the sulphur content to $60.16 \%$. This RGO-S hybrid showed a large reversible capacity of $773 \mathrm{~mA} \cdot \mathrm{h} \cdot \mathrm{g}^{-1}$ and 
$662 \mathrm{~mA} \cdot \mathrm{h} \cdot \mathrm{g}^{-1}$ after 100 cycles at $0.5 \mathrm{C}$ and $1 \mathrm{C}$, respectively. It is known that the hydrothermal method is a simple and effective strategy to form the 3D structures; thus, a variety of 3D-RGO-S composites have been synthesised by this hydrothermal reduction method [150-153], and the as-prepared RGO-S illustrated excellent electrochemical performance. For example, when the RGO sponges underwent melt-diffusion with the sulphur, they retained the 3D structures (as shown in Figure 12a,b) [151]. Due to this unique 3D structure, it showed a reversible and comparable capacity of $4.53 \mathrm{~mA} \cdot \mathrm{h} \cdot \mathrm{cm}^{-2}$ after 300 cycles (Figure 12c), corresponding to capacity retention of $75.5 \%$ (of its highest capacity of $6.0 \mathrm{~mA} \cdot \mathrm{h} \cdot \mathrm{cm}^{-2}$ ), resulting in a decay rate as low as $0.08 \%$ per cycle for 300 cycles.
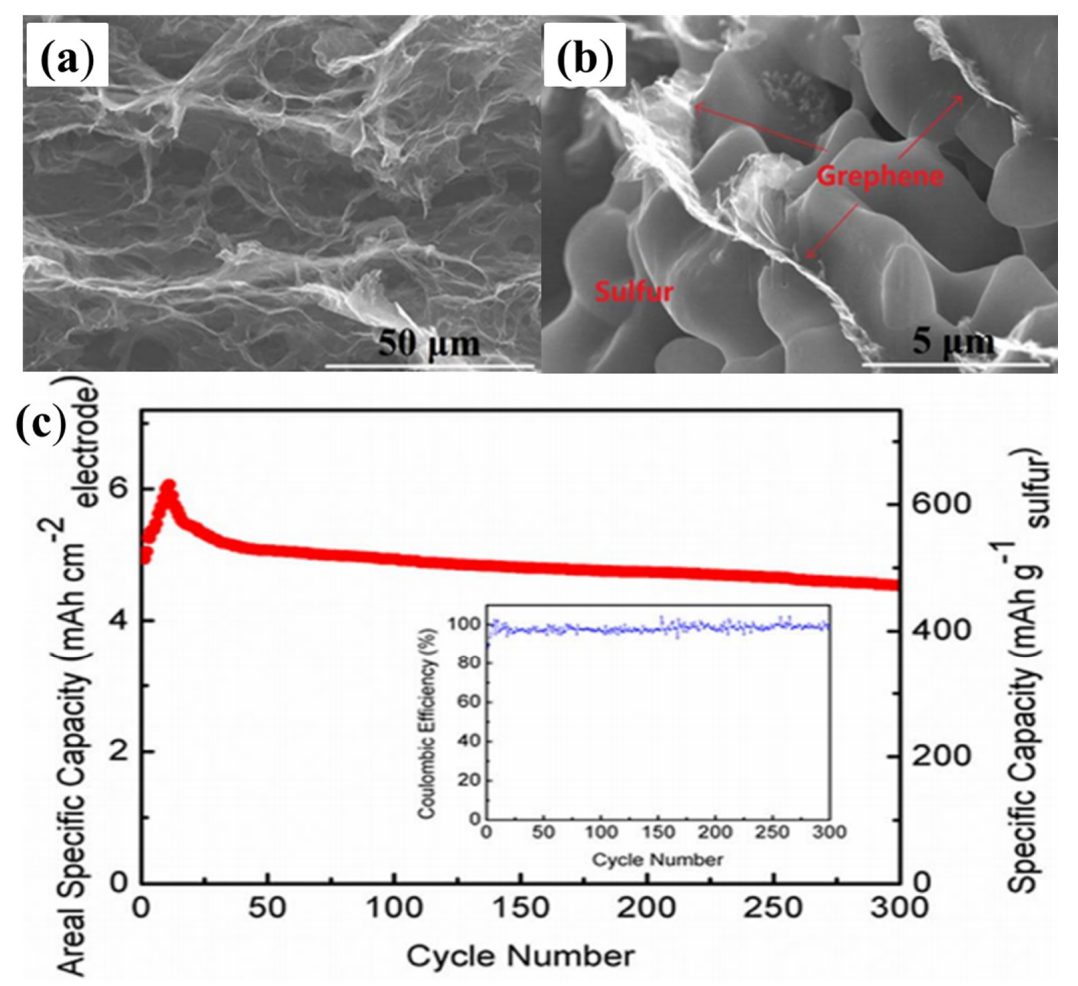

Figure 12. SEM image of the interior microstructures of (a) the GO sponges; and (b) S-GS with $80 \mathrm{wt} \%$ sulphur; (c) cyclic performance and Coulombic efficiency of the S-GS cathode for a Li-S battery at a current density of $0.1 \mathrm{C}$ for 300 cycles. The inset is the Coulombic efficiency [151]. Reproduced with permission from [151]. Copyright 2015, Nature Publishing Group.

Thermal pyrolysis is also widely used for the reduction of GO. Researchers annealed GO at high temperature in inert atmospheres, such as $\mathrm{Ar}$ [154-156], $\mathrm{N}_{2}$ [157], $\mathrm{Ar} / \mathrm{H}_{2}$ [158], as well as in vacuum conditions [159]. As these RGOs are obtained at high temperature, they tend to show excellent conductivity, and could thus accelerate electron transfer, enhance the reaction kinetics, and improve the active materials utilization during the charge/discharge process.

Using chemically reducing agents (e.g., $\mathrm{Na}_{2} \mathrm{~S}$ ) to reduce the $\mathrm{GO}$ could also yield highly conductive RGO ready for sulphur loading. Nazar's group [160] prepared a RGO-S composite combining a mixture of $\mathrm{GO}$ and the soluble polysulphide $\mathrm{Na}_{2} \mathrm{~S}_{2.4}$ as both the $\mathrm{S}$ source and reductant, while Sun's group used the $\mathrm{Na}_{2} \mathrm{SO}_{3}$ as the sulphur source and the $\mathrm{Na}_{2} \mathrm{~S}$ as the reducing agent [161]. Recently, Du's group [162] reported a RGO-S composite preparation, again by using $\mathrm{Na}_{2} \mathrm{SO}_{3}$ as the sulphur source, but hydrazine as the reducing agent. By using PVP, the sulphur nanospheres $(400-500 \mathrm{~nm})$ were first uniformly wrapped by conductive $\mathrm{GO}$ sheets through the electrostatic interaction between GO and PVP, followed by the reduction of GO with hydrazine. As a result, the RGO-S composite with $91 \mathrm{wt} \%$ sulphur showed a reversible initial capacity of $970 \mathrm{~mA} \cdot \mathrm{h} \cdot \mathrm{g}^{-1}$ and an average Coulombic efficiency $>96 \%$ over 100 cycles at a rate of $0.2 \mathrm{C}$. Moreover, there are some other kinds of reducing 
agents which have been applied during the fabrication of RGO-S composites, such as HI [163,164], $\mathrm{H}_{2} \mathrm{~S}$ [165,166], urea [167], etc. Table 4 compares the performances of various RGO-S composites using different reduction methods or reducing agents.

Table 4. Electrochemical performances of various graphene composites in Li-S batteries. 3D: three-dimensional; AG: activated graphene; MGP: mesoporous graphene paper; GnPs: graphene nanoplatelets; CP: carbon paper; GSC: graphene-sulfur composite; SGC: S-RGO composite; HDGS: highly dense RGO/sulfur; HRGO: $\mathrm{H}_{2} \mathrm{~S}-\mathrm{RGO}$; and GES: graphene-encapsulated sulfur.

\begin{tabular}{|c|c|c|c|c|}
\hline Composite Name & $\begin{array}{c}\text { Reducing } \\
\text { Agent/Method }\end{array}$ & $\begin{array}{l}\text { Sulphur Content } \\
\text { in Graphene/RGO } \\
\text { Composite (wt } \% \text { ) }\end{array}$ & $\begin{array}{l}\text { Reversible Capability } \\
\text { (at } n \text {th Cycle and C-Rate) }\end{array}$ & Reference \\
\hline RGO-S & \multirow{6}{*}{ Hydrothermal } & 22 & $\sim 550 \mathrm{~mA} \cdot \mathrm{h} \cdot \mathrm{g}^{-1}\left(40 \mathrm{th}, 50 \mathrm{~mA} \cdot \mathrm{g}^{-1}\right)$ & [148] \\
\hline S-graphene & & 75.2 & $662 \mathrm{~mA} \cdot \mathrm{h} \cdot \mathrm{g}^{-1}\left(100 \mathrm{th}, 1000 \mathrm{~mA} \cdot \mathrm{g}^{-1}\right)$ & [149] \\
\hline Dense S-graphene & & 69.6 & $770 \mathrm{~mA} \cdot \mathrm{h} \cdot \mathrm{g}^{-1}(300 \mathrm{th}, 0.5 \mathrm{C})$ & [150] \\
\hline S-GS & & 80 & $4.53 \mathrm{~mA} \cdot \mathrm{h} \cdot \mathrm{cm}^{-2}(300 \mathrm{th}, 0.1 \mathrm{C})$ & [151] \\
\hline S@3D-graphene & & 73 & $700 \mathrm{~mA} \cdot \mathrm{h} \cdot \mathrm{g}^{-1}(100 \mathrm{th}, 0.1 \mathrm{C})$ & [152] \\
\hline Graphene-S & & 63 & $541 \mathrm{~mA} \cdot \mathrm{h} \cdot \mathrm{g}^{-1}\left(100 \mathrm{th}, 750 \mathrm{~mA} \cdot \mathrm{g}^{-1}\right)$ & [153] \\
\hline $\mathrm{AG} / \mathrm{S}$ & \multirow{3}{*}{$\begin{array}{l}\text { Ar Thermal } \\
\text { Pyrolysis }\end{array}$} & 65 & $717.1 \mathrm{~mA} \cdot \mathrm{h} \cdot \mathrm{g}^{-1}\left(200 \mathrm{th}, 1000 \mathrm{~mA} \cdot \mathrm{g}^{-1}\right)$ & {$[154]$} \\
\hline MGP-S & & 55 & $689 \mathrm{~mA} \cdot \mathrm{h} \cdot \mathrm{g}^{-1}(50 \mathrm{th}, 0.1 \mathrm{C})$ & {$[155]$} \\
\hline S-GnPs-CP & & 70 & $\sim 700 \mathrm{~mA} \cdot \mathrm{h}^{-\mathrm{g}^{-1}}(500 \mathrm{th}, 2 \mathrm{C})$ & [156] \\
\hline S/RGO & $\begin{array}{l}\mathrm{N}_{2} \text { Thermal } \\
\text { Pyrolysis }\end{array}$ & 60 & $625 \mathrm{~mA} \cdot \mathrm{h} \cdot \mathrm{g}^{-1}(200 \mathrm{th}, 0.1 \mathrm{C})$ & [157] \\
\hline S-RGO & $\begin{array}{l}\mathrm{H}_{2} / \text { Ar Thermal } \\
\text { Pyrolysis }\end{array}$ & 63 & $658 \mathrm{~mA} \cdot \mathrm{h} \cdot \mathrm{g}^{-1}\left(200 \mathrm{th}, 500 \mathrm{~mA} \cdot \mathrm{g}^{-1}\right)$ & [158] \\
\hline $\mathrm{RGO} / \mathrm{S}$ & $\begin{array}{l}\text { Vacuum Thermal } \\
\text { Pyrolysis }\end{array}$ & 52 & $\sim 880 \mathrm{~mA} \cdot \mathrm{h} \cdot \mathrm{g}^{-1}\left(220 \mathrm{th}, 100 \mathrm{~mA} \cdot \mathrm{g}^{-1}\right)$ & {$[159]$} \\
\hline GSC & $\mathrm{Na}_{2} \mathrm{~S}_{\sim 2.4}$ & 87 & $550 \mathrm{~mA} \cdot \mathrm{h} \cdot \mathrm{g}^{-1}(50 \mathrm{th}, 0.2 \mathrm{C})$ & [160] \\
\hline SGC & $\mathrm{Na}_{2} \mathrm{~S}$ & 63.6 & $440 \mathrm{~mA} \cdot \mathrm{h} \cdot \mathrm{g}^{-1}(500 \mathrm{th}, 0.75 \mathrm{C})$ & [161] \\
\hline $\begin{array}{l}\text { S-nanosphere } \\
\text { @graphene }\end{array}$ & Hydrazine & 91 & $430 \mathrm{~mA} \cdot \mathrm{h} \cdot \mathrm{g}^{-1}(100 \mathrm{th}, 0.2 \mathrm{C})$ & [162] \\
\hline RGO/S & \multirow{2}{*}{$\mathrm{HI}$} & 80 & $720 \mathrm{~mA} \cdot \mathrm{h} \cdot \mathrm{g}^{-1}\left(50 \mathrm{th}, 0.5 \mathrm{~mA} \cdot \mathrm{cm}^{-2}\right)$ & {$[163]$} \\
\hline S@RGO & & 85 & $480 \mathrm{~mA} \cdot \mathrm{h} \cdot \mathrm{g}^{-1}(200 \mathrm{th}, 0.05 \mathrm{C})$ & {$[164]$} \\
\hline HDGS & \multirow{2}{*}{$\mathrm{H}_{2} \mathrm{~S}$} & 32 & $\sim 100 \mathrm{~mA} \cdot \mathrm{h} \cdot \mathrm{cm}^{-2}(300 \mathrm{th}, 0.8 \mathrm{C})$ & {$[165]$} \\
\hline HRGO/S & & $\sim 50$ & $\sim 525 \mathrm{~mA} \cdot \mathrm{h} \cdot \mathrm{g}^{-1}\left(100 \mathrm{th}, 500 \mathrm{~mA} \cdot \mathrm{g}^{-1}\right)$ & [166] \\
\hline GES & Urea & 83.3 & $523.1 \mathrm{~mA} \cdot \mathrm{h} \cdot \mathrm{g}^{-1}(500 \mathrm{th}, 3 \mathrm{C})$ & [167] \\
\hline
\end{tabular}

It is common sense that RGOs derived from the reduction method are multilayered and easily crumpled, whereas single-layered graphene is mechanically stronger and would display superior electrochemical properties when compared to the performances obtained from multilayered graphene composites. With the purpose of obtaining high quality graphene for assembling the high-performance graphene-S cathodes, researchers developed a template-synthesis strategy to obtain the desired few-layered grapheme (FLG). Kumar's group [168] synthesised a FLG foam by chemical vapor deposition (CVD) via a sacrificial Ni foam template method, followed by drop casting of the sulphur for infiltration into the FLG foam. The obtained free-standing S-FLG foam cathode revealed good electrochemical stability and high rate discharge capacity retention for up to 400 discharge/charge cycles at a high current density of $3200 \mathrm{~mA} \cdot \mathrm{g}^{-1}$. Wei's group [169] used layered double hydroxide nanoflakes as the templates to synthesise double-layer graphene. This unstacked graphene exhibited a $3 \mathrm{D}$ topological porous system, which is suitable for accommodating the active materials. The resulting Li-S batteries demonstrated not only excellent cycling stability, but also superior rate capability.

$\mathrm{RGO/graphene} \mathrm{can} \mathrm{be} \mathrm{surface-functionalized} \mathrm{or} \mathrm{doped} \mathrm{with} \mathrm{heteroatoms} \mathrm{for} \mathrm{a} \mathrm{better} \mathrm{immobilization}$ of sulphur by chemical adsorption. In 2014, Lou's group reported that the amino-functionalized RGO 
could strongly bind the discharge products $\left(\mathrm{Li}_{2} \mathrm{~S}\right.$ and $\left.\mathrm{Li}_{2} \mathrm{~S}_{2}\right)$ to the surface of the cathode [170]. As a result, the RGO enabled the Li-S batteries to display excellent stable capacity retention of $80 \%$ for 350 cycles. Recently, Wang's group reported a synthesis of highly crumpled nitrogen-doped graphene sheets (GS) with ultrahigh pore volume $\left(5.4 \mathrm{~cm}^{3} \cdot \mathrm{g}^{-1}\right)$ via a simple thermally induced expansion strategy [171]. Due to the unique pore structure and nitrogen-doping, a strong polysulphide adsorption ability was induced, and Li-S batteries using these wrinkled GS as both the sulphur host and interlayer achieved a high capacity of $\sim 1000 \mathrm{~mA} \cdot \mathrm{h} \cdot \mathrm{g}^{-1}$ and exceptional cycling stability, even at high sulphur content $(\geq 80 \mathrm{wt} \%)$ and sulphur loading (5 $\mathrm{mg}$ sulphur $/ \mathrm{cm}^{2}$ ).

\subsection{Carbon Interlayers for Lithium-Sulphur Batteries}

Discovering novel battery configurations in Li-S systems is another strategy to accommodate the diffusion of polysulphides towards the anode side [172]. The emerging research in the field of interlayers contributes to the significant improvements in the electrochemical performance of Li-S systems.

Manthiram's group [173] first reported a microporous carbon paper (MCP) inserted between the cathode and separator, as shown in Figure 13a. With the bifunctional MCP between the cathode and separator, a significant improvement not only in the active material utilization, but also in capacity retention was obtained, and the cyclability at $1 \mathrm{C}$ rate retained over $1000 \mathrm{~mA} \cdot \mathrm{h} \cdot \mathrm{g}^{-1}$ after $100 \mathrm{cycles}$, converting to a retention rate of $85 \%$ with an average Coulombic efficiency of $97.6 \%$. Since then, all kinds of porous carbon—such as biomass derived carbon [174-177], porous carbon fibre [18,178-186], CNTs [187-189], Ketjen black (KB) in polytetrafluoroethylene (PTFE) latex [190], etc.- -have been employed as the interlayer as shown in Table 5 and Figure 13b-d.

Table 5. Electrochemical performance of carbon interlayers in Li-S batteries. MCP: microporous carbon paper; ACNF: activated CNF; and PTFE: polytetrafluoroethylene.

\begin{tabular}{|c|c|c|c|}
\hline Carbon Interlayer Type & $\begin{array}{l}\text { Sulphur Loading } \\
\text { in the Electrode }\end{array}$ & $\begin{array}{l}\text { Reversible Capability } \\
\text { (at } n \text {th Cycle and C-Rate) }\end{array}$ & Reference \\
\hline Nitrogen and phosphorous dual-doped graphene & $70 \%$ & $638 \mathrm{~mA} \cdot \mathrm{h} \cdot \mathrm{g}^{-1}(500 \mathrm{th}, 1 \mathrm{C})$ & [7] \\
\hline Bamboo carbon fiber & $70 \%$ & $605.7 \mathrm{~mA} \cdot \mathrm{h} \cdot \mathrm{g}^{-1}(300 \mathrm{th}, 1 \mathrm{C})$ & [18] \\
\hline $\mathrm{MCP}$ & $70 \%$ & $1000 \mathrm{~mA} \cdot \mathrm{h} \cdot \mathrm{g}^{-1}(100 \mathrm{th}, 1 \mathrm{C})$ & [173] \\
\hline Carbonized eggshell membrane & $3.0-3.2 \mathrm{mg} \cdot \mathrm{cm}^{-2}$ & $1000 \mathrm{~mA} \cdot \mathrm{h} \cdot \mathrm{g}^{-1}(100 \mathrm{th}, 0.1 \mathrm{C})$ & [174] \\
\hline Carbonized leaf & $1.3 \mathrm{mg} \cdot \mathrm{cm}^{-2}$ & $800 \mathrm{~mA} \cdot \mathrm{h} \cdot \mathrm{g}^{-1}(150 \mathrm{th}, 0.5 \mathrm{C})$ & [175] \\
\hline Cassava-derived carbon sheet & $1.6 \mathrm{mg} \cdot \mathrm{cm}^{-2}$ & $811 \mathrm{~mA} \cdot \mathrm{h} \cdot \mathrm{g}^{-1}(100 \mathrm{th}, 0.5 \mathrm{C})$ & {$[176]$} \\
\hline Filamentous fungi-derived carbon & $60 \%$ & $650 \mathrm{~mA} \cdot \mathrm{h} \cdot \mathrm{g}^{-1}(100 \mathrm{th}, 0.5 \mathrm{C})$ & {$[177]$} \\
\hline Carbonized non-woven fabrics films & $2 \mathrm{mg} \cdot \mathrm{cm}^{-2}$ & $677 \mathrm{~mA} \cdot \mathrm{h} \cdot \mathrm{g}^{-1}(100 \mathrm{th}, 1 \mathrm{C})$ & [178] \\
\hline Hierarchical carbonized paper & $1.1 \mathrm{mg} \cdot \mathrm{cm}^{-2}$ & $780 \mathrm{~mA} \cdot \mathrm{h} \cdot \mathrm{g}^{-1}(200 \mathrm{th}, 2 \mathrm{C})$ & {$[179]$} \\
\hline Porous carbon mat & $1.45 \mathrm{mg} \cdot \mathrm{cm}^{-2}$ & $527 \mathrm{~mA} \cdot \mathrm{h} \cdot \mathrm{g}^{-1}(400 \mathrm{th}, 1 \mathrm{C})$ & [180] \\
\hline Carbonized bacterial cellulose & $81 \%$ & $620 \mathrm{~mA} \cdot \mathrm{h} \cdot \mathrm{g}^{-1}\left(300 \mathrm{th}, 800 \mathrm{~mA} \cdot \mathrm{g}^{-1}\right)$ & {$[181]$} \\
\hline PI-based ACNFs & $2.5 \pm 0.1 \mathrm{mg} \cdot \mathrm{cm}^{-2}$ & $897 \mathrm{~mA} \cdot \mathrm{h} \cdot \mathrm{g}^{-1}(100 \mathrm{th}, 0.1 \mathrm{C})$ & {$[182]$} \\
\hline Polypyrrole-supported carbon & $70 \%$ & $555 \mathrm{~mA} \cdot \mathrm{h} \cdot \mathrm{g}^{-1}(200 \mathrm{th}, 0.5 \mathrm{C})$ & {$[183]$} \\
\hline Filter paper derived carbon & $70 \%$ & $560 \mathrm{~mA} \cdot \mathrm{h} \cdot \mathrm{g}^{-1}(50 \mathrm{th}, 1 \mathrm{C})$ & [184] \\
\hline $\mathrm{CNF} / \mathrm{RGO}$ & $1.40 \mathrm{mg} \cdot \mathrm{cm}^{-2}$ & $533.6 \mathrm{~mA} \cdot \mathrm{h} \cdot \mathrm{g}^{-1}(400 \mathrm{th}, 1 \mathrm{C})$ & [185] \\
\hline Carbon paper & $60 \%$ & $929 \mathrm{~mA} \cdot \mathrm{h} \cdot \mathrm{g}^{-1}(100 \mathrm{th}, 1 \mathrm{C})$ & {$[186]$} \\
\hline MWCNTs & $1.20 \mathrm{mg} \cdot \mathrm{cm}^{-2}$ & $1200 \mathrm{~mA} \cdot \mathrm{h} \cdot \mathrm{g}^{-1}(100 \mathrm{th}, 1 \mathrm{C})$ & {$[187]$} \\
\hline $\mathrm{TiO}_{2}-\mathrm{CNTs}$ & $1.8 \mathrm{mg} \cdot \mathrm{cm}^{-2}$ & $848 \mathrm{~mA} \cdot \mathrm{h} \cdot \mathrm{g}^{-1}(100 \mathrm{th}, 5 \mathrm{C})$ & [188] \\
\hline MWCNTs & $70 \%$ & $804 \mathrm{~mA} \cdot \mathrm{h} \cdot \mathrm{g}^{-1}(100 \mathrm{th}, 1 \mathrm{C})$ & [189] \\
\hline KB in PTFE latex & $4.0 \mathrm{mg} \cdot \mathrm{cm}^{-2}$ & $1000 \mathrm{~mA} \cdot \mathrm{h} \cdot \mathrm{g}^{-1}(150 \mathrm{th}, 0.5 \mathrm{C})$ & {$[190]$} \\
\hline $\mathrm{Al}_{2} \mathrm{O}_{3}$-porous carbon cloth & $1.2 \mathrm{mg} \cdot \mathrm{cm}^{-2}$ & $766 \mathrm{~mA} \cdot \mathrm{h} \cdot \mathrm{g}^{-1}\left(40 \mathrm{th}, 40 \mathrm{~mA} \cdot \mathrm{g}^{-1}\right)$ & {$[191]$} \\
\hline Carbon-nanotube paper-titanium dioxide & $70 \%$ & $575.8 \mathrm{~mA} \cdot \mathrm{h} \cdot \mathrm{g}^{-1}(250 \mathrm{th}, 0.5 \mathrm{C})$ & [192] \\
\hline $\mathrm{Fe}_{3} \mathrm{C} / \mathrm{CNF}$ web & $70 \%$ & $893 \mathrm{~mA} \cdot \mathrm{h} \cdot \mathrm{g}^{-1}\left(100 \mathrm{th}, 200 \mathrm{~mA} \cdot \mathrm{g}^{-1}\right)$ & [193] \\
\hline RGO-carbon black & $80 \%$ & $895 \mathrm{~mA} \cdot \mathrm{h} \cdot \mathrm{g}^{-1}(100 \mathrm{th}, 0.1 \mathrm{C})$ & {$[194]$} \\
\hline Nitrogen-doped graphene & $0.4-0.5 \mathrm{mg} \cdot \mathrm{cm}^{-2}$ & $\sim 400 \mathrm{~mA} \cdot \mathrm{h} \cdot \mathrm{g}^{-1}(100 \mathrm{th}, 2 \mathrm{C})$ & [195] \\
\hline
\end{tabular}



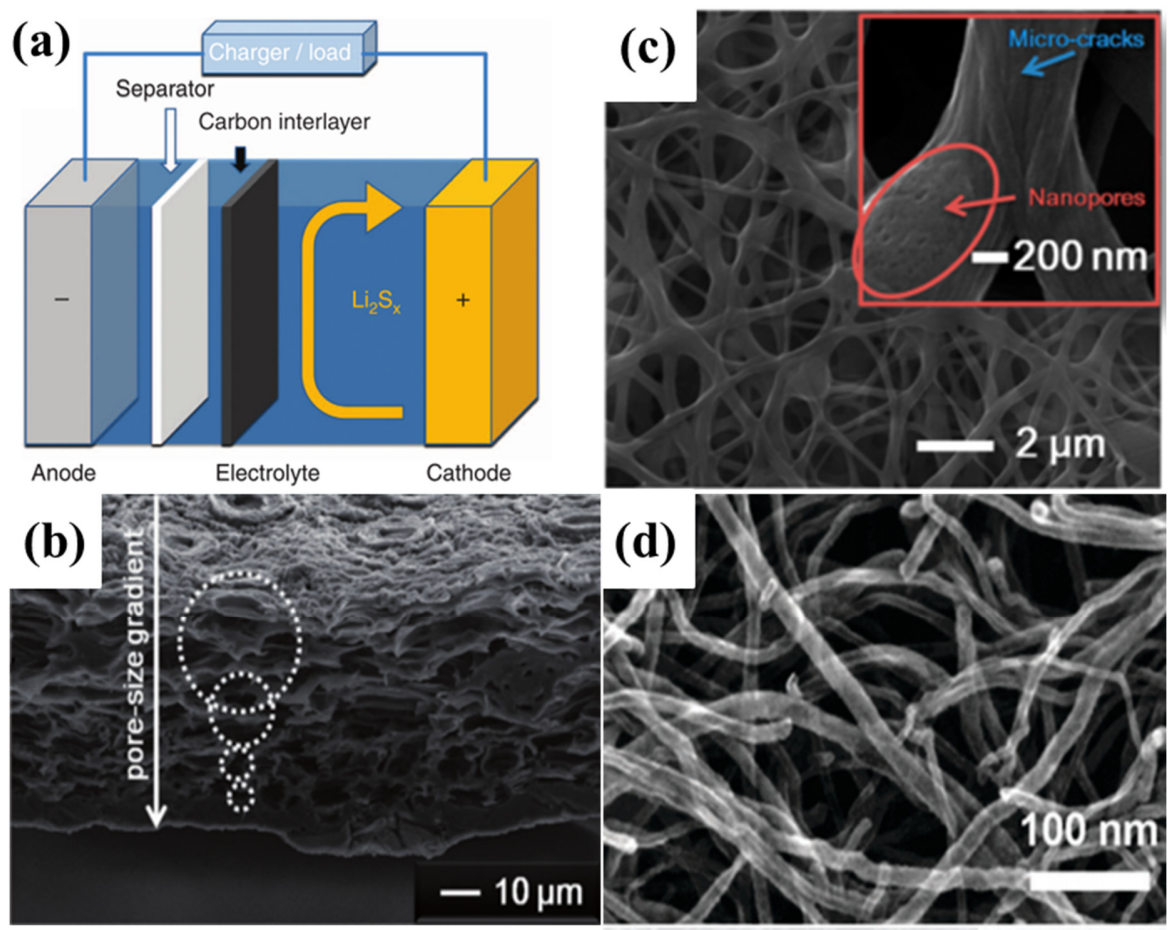

Figure 13. (a) Scheme of the porous carbon employed as the interlayer in the Li-S battery [173]. Reproduced with permission from [173]. Copyright 2012, Nature Publishing Group. (b) A SEM image of natural carbonized leaf with abundant pores [175]. Reproduced with permission from [175]. Copyright 2014, Wiley-VCH, American Chemical Society. (c) SEM image of porous carbon fiber [180]. Reproduced with permission from [180]. Copyright 2015, American Chemical Society. (d) SEM image of MWCNTs paper [189]. Reproduced with permission from [189]. Copyright 2012, The Royal Society of Chemistry.

Recently, researchers found that a carbon matrix mixed with bits of metal complex could be employed as the interlayer and could further improve the cycling performances of the Li-S batteries when compared to the performances obtained when using a cell with a single carbon matrix interlayer. For example, as early as 2013, Hu's group [191] demonstrated the effect of atomic layer deposited (ALD) $\mathrm{Al}_{2} \mathrm{O}_{3}$ on the reactivation of dissolved polysulphides in Li-S batteries. A 0.5 nm-thick layer of $\mathrm{Al}_{2} \mathrm{O}_{3}$ was conformably coated onto highly porous carbon cloth by ALD, and then assembled in a Li-S battery as the interlayer. Compared to half cells without ALD treatment, the ultrathin $\mathrm{Al}_{2} \mathrm{O}_{3}$ coating increased the specific discharge capacity by $25 \%$ from $907 \mathrm{~mA} \cdot \mathrm{h} \cdot \mathrm{g}^{-1}$ to $1136 \mathrm{~mA} \cdot \mathrm{h} \cdot \mathrm{g}^{-1}$ at the first cycle, and by $114 \%$ from $358 \mathrm{~mA} \cdot \mathrm{h} \cdot \mathrm{g}^{-1}$ to $766 \mathrm{~mA} \cdot \mathrm{h} \cdot \mathrm{g}^{-1}$ at the 40 th cycle. Recently, Zhang and his co-workers [192] reported that a multifunctional carbon-nanotube paper/titanium-dioxide barrier effectively reduced active material loss and suppressed the diffusion of lithium polysulphides to the anode. Using this interlayer, an activated carbon/sulphur cathode with $70 \%$ sulphur content delivered stable cycling performance and high Coulombic efficiency ( 99\%) over 250 cycles at a current rate of $0.5 \mathrm{C}$. Huang et al. [193] reported a new freestanding $\mathrm{Fe}_{3} \mathrm{C} / \mathrm{CNF}$ film as an interlayer for high performance Li-S batteries. The battery delivered an excellent specific discharge capacity of $893 \mathrm{~mA} \cdot \mathrm{h} \cdot \mathrm{g}^{-1}$ after 100 cycles, maintaining $76 \%$ of its initial capacity of $1177 \mathrm{~mA} \cdot \mathrm{h} \cdot \mathrm{g}^{-1}$.

In addition, graphene-due to its unique $2 \mathrm{D}$ dimensional structure and high conductivity-is also a good candidate for use as an interlayer for Li-S batteries. As early as 2013, a kind of RGO was applied as the interlayer for Li-S batteries by Wang's group [194]. The Li-S cell with such a RGO interlayer showed an initial discharge capacity of $1260 \mathrm{~mA} \cdot \mathrm{h} \cdot \mathrm{g}^{-1}$, with the capacity remaining at $895 \mathrm{~mA} \cdot \mathrm{h} \cdot \mathrm{g}^{-1}$ after 100 cycles. Later, functionalized graphene and heteroatom-doped graphene membranes were developed as the interlayers for Li-S batteries. For instance, Kung's group [195] 
used a kind of free-standing N-doped graphene paper as an interlayer to entrap polysulphides. Density functional theory (DFT) calculations were used to indicate that pyrrolic and pyridinic $\mathrm{N}$ atoms interacted more strongly with Li polysulphides than quaternary $\mathrm{N}$ atoms. More recently, our group synthesized a porous $\mathrm{N}$ and P-dual doped graphene (P-NP-G) and applied it as a blocking layer [7]. After comparative study, the Li-S battery with P-NP-G demonstrated better electrochemical performance than that with the single $\mathrm{N}$ - or P-doped graphene. We also used DFT calculations to help understand the mechanisms, and found the $\mathrm{P}$ atoms and $-\mathrm{P}-\mathrm{O}$ groups in the P-NP-G layer offered stronger adsorption to the polysulphides than the $\mathrm{N}$ species.

\subsection{Carbon-Modified Separators}

Carbon materials are widely applied as the conductive scaffolds for $\mathrm{Li}-\mathrm{S}$ batteries. By the facile modification of a separator with carbon, the polysulphide species diffusing towards the anode side were trapped. In addition, the conductive carbon facilitated the complex reactions by forming an upper current collector on the top surface of cathode materials [172].

Manthiram's group [196] reported a series of pioneer discoveries in this research field, such as a bifunctional separator with a light-weight Super P carbon-coating that-when used in a Li-S cell—displayed a high initial discharge capacity of $1389 \mathrm{~mA} \cdot \mathrm{h} \cdot \mathrm{g}^{-1}$ with excellent dynamic stability, and a high reversible capacity of $828 \mathrm{~mA} \cdot \mathrm{h} \cdot \mathrm{g}^{-1}$ after 200 cycles. A custom separator with an activated CNF (ACNF) filter coated onto a polypropylene membrane was presented [197]. The optimal ACNF20-filter-coated separator demonstrated an overall superior boost in the electrochemical utilization (discharge capacity: $1270 \mathrm{~mA} \cdot \mathrm{h} \cdot \mathrm{g}^{-1}$ ) and polysulphide retention (capacity fade rate: $0.13 \%$ cycle $^{-1}$ after 200 cycles). A MWCNTs-modified separator employed as an ultra-light weight bundled polysulphide filter was also developed [198]. The conductive/porous MWCNTs coating acted as an upper current collector, which helped to facilitate electron transport and high active material utilization, as well as acting as a filter to intercept/absorb the migrating polysulphides which suppressed the polysulphide diffusion. As a result, a high discharge capacity of $1324 \mathrm{~mA} \cdot \mathrm{h} \cdot \mathrm{g}^{-1}$ was achieved, and capacity decay rate of as low as $0.14 \%$ was achieved. Moreover, his group also reported single-walled carbon nanotube (SWCNTs)-modulated separators for high performance Li-S batteries [199]. Compared to the simple component of Super P and MWCNTs, a novel separator with a polyethylene glycol (PEG)-supported microporous carbon composite coating was also employed as a polysulphide shelter [200]. The use of MPC substrates aims to physically trap the migrating polysulphide by their micropores. The use of a PEG binder can chemically improve the polysulphide trapping capability and enhance the mechanical strength of the MPC/PEG coating. The MPC/PEG-coated separator allowed the successful implementation of a pure sulphur cathode containing $70 \mathrm{wt} \%$ sulphur and led to high discharge capacities, stable cyclability, and good rate performance. After upgrading the Celgard separator to the MPC/PEG-coated separator, the initial discharge capacities (with sulphur utilization) increased from $843 \mathrm{~mA} \cdot \mathrm{h} \cdot \mathrm{g}^{-1}(50 \%)$ to $1307 \mathrm{~mA} \cdot \mathrm{h} \cdot \mathrm{g}^{-1}$ (78\%) and from $543 \mathrm{~mA} \cdot \mathrm{h} \cdot \mathrm{g}^{-1}(32 \%)$ to $1018 \mathrm{~mA} \cdot \mathrm{h} \cdot \mathrm{g}^{-1}(61 \%)$ at $\mathrm{C} / 5$ and $\mathrm{C} / 2$ rates, respectively.

In 2014, Cheng's group [201] used one graphene membrane as a current collector (GCC) which was coated with the active pure sulphur, and another graphene membrane coated on the separator (denoted as GCC/S + G-separator as shown in Figure 14a-c). The flexible and conductive graphene layers on both sides of the sulphur electrode provided excellent electric conductivity. The sandwich structure was believed to effectively accommodate the large volumetric expansion of sulphur during lithiation. The battery with a GCC/S + G-separator delivered capacities as high as $1000 \mathrm{~mA} \cdot \mathrm{h} \cdot \mathrm{g}^{-1}$ and $750 \mathrm{~mA} \cdot \mathrm{h} \cdot \mathrm{g}^{-1}$ at $1.5 \mathrm{~A} / \mathrm{g}$ and $6 \mathrm{~A} / \mathrm{g}$, respectively, which are roughly 2 and 50 times higher, respectively, than those of the battery with a $\mathrm{Al}$ foil/S + separator tested under the same conditions as shown in Figure 14d. 


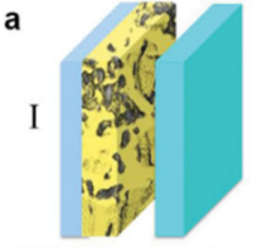

Al foil/S+separator

$$
\text { b }
$$
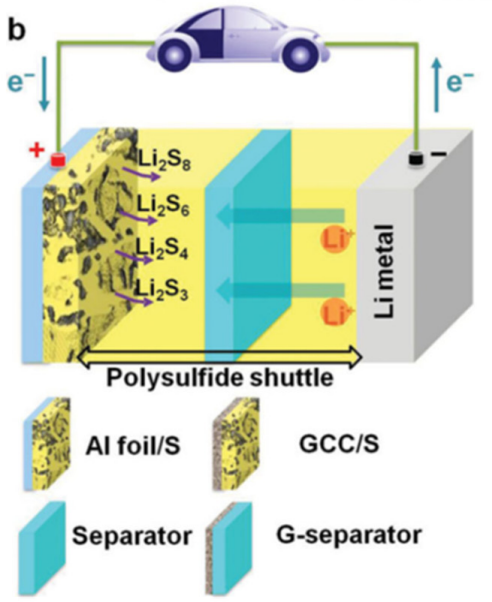

III

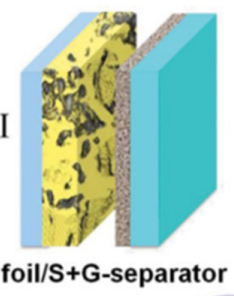

IV

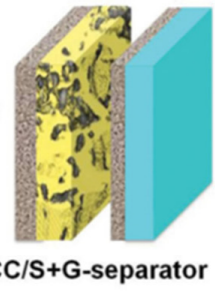

C

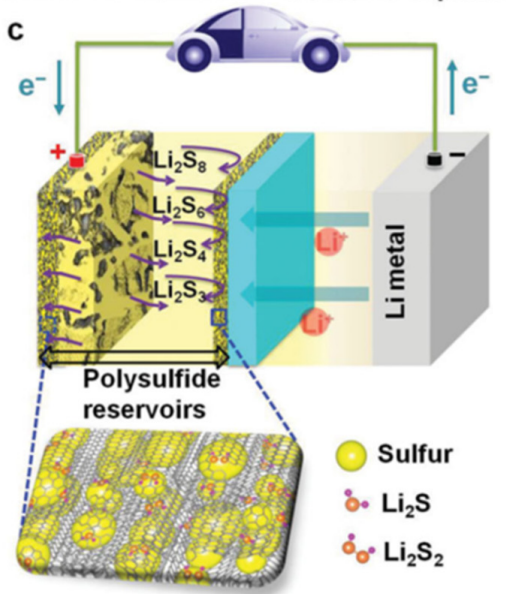

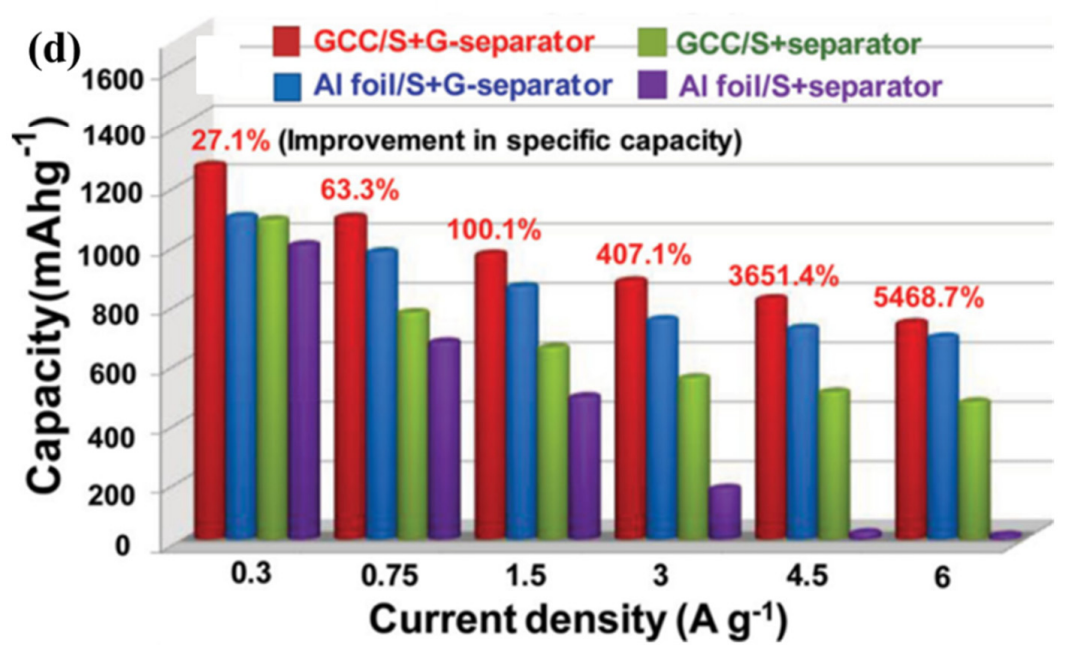

Figure 14. (a) Schematic of electrode configurations of: (I) an Al foil, sulphur cathode, and commercial separator (Al foil/S + separator); (II) a graphene current collector (GCC), sulphur cathode, and commercial separator (GCC/S + separator); (III) an Al foil, sulphur cathode, and G-separator (Al foil/S + G-separator); and (IV) a GCC, sulphur cathode, and G-separator. (b) Schematic of a Li-S battery with electrode configuration I. (c) Schematic of a Li-S battery with electrode configuration IV. The paler yellow color represents the reduced shuttle effect. (d) Rate performance of the Li-S batteries with different configurations at different current densities [201]. Reproduced with permission from [201]. Copyright 2013, Wiley-VCH.

Following Manthiram and Chen's research groups, various kinds of carbon and carbon-based composites-such as mesoporous carbon [202,203], nitrogen-doped hollow porous carbon spheres [204], KB [205], acetylene black and carbon nano-tube composites [206], GO [207,208], cellular graphene [209], polyvinylidene fluoride-carbon [210], MWCNTs@PEG composite [211], etc.—have been employed to modify the separator in order to improve the cycling performances of Li-S batteries, and the Table 6 illustrates the electrochemical performances of the Li-S batteries by using these various carbon modified separators. 
Table 6. Electrochemical performances of carbon modified separators in Li-S batteries. SWCNTs: single-walled carbon nanotubes; and PEG: polyethylene glycol.

\begin{tabular}{|c|c|c|c|}
\hline Carbon Modified Separator & $\begin{array}{l}\text { Sulphur Content } \\
\text { in the Electrode }\end{array}$ & $\begin{array}{l}\text { Reversible Capability } \\
\text { (at } n \text {th Cycle and C-Rate) }\end{array}$ & Reference \\
\hline Super P modified separator & $1.1-1.3 \mathrm{mg} \cdot \mathrm{cm}^{-2}$ & $701 \mathrm{~mA} \cdot \mathrm{h} \cdot \mathrm{g}^{-1}(200 \mathrm{th}, 2 \mathrm{C})$ & [196] \\
\hline ACNF modified separator & $2.1-2.3 \mathrm{mg} \cdot \mathrm{cm}^{-2}$ & $819 \mathrm{~mA} \cdot \mathrm{h} \cdot \mathrm{g}^{-1}(200 \mathrm{th}, 2 \mathrm{C})$ & [197] \\
\hline MWCNTs modified separator & $70 \%$ & $621 \mathrm{~mA} \cdot \mathrm{h} \cdot \mathrm{g}^{-1}(300 \mathrm{th}, 1 \mathrm{C})$ & [198] \\
\hline SWCNTs modulated separator & $6.3 \mathrm{mg} \cdot \mathrm{cm}^{-2}$ & $500 \mathrm{~mA} \cdot \mathrm{h} \cdot \mathrm{g}^{-1}(100 \mathrm{th}, 0.2 \mathrm{C})$ & [199] \\
\hline $\begin{array}{l}\text { PEG-microporous carbon } \\
\text { modified separator }\end{array}$ & $70 \%$ & $596 \mathrm{~mA} \cdot \mathrm{h} \cdot \mathrm{g}^{-1}(500 \mathrm{th}, 0.2 \mathrm{C})$ & [200] \\
\hline Graphene modified separator & $70 \%$ & $680 \mathrm{~mA} \cdot \mathrm{h} \cdot \mathrm{g}^{-1}\left(300 \mathrm{th}, 1500 \mathrm{~mA} \cdot \mathrm{g}^{-1}\right)$ & [201] \\
\hline Mesoporous carbon modified separator & $1.55 \mathrm{mg} \cdot \mathrm{cm}^{-2}$ & $591 \mathrm{~mA} \cdot \mathrm{h} \cdot \mathrm{g}^{-1}(500 \mathrm{th}, 2 \mathrm{C})$ & [202] \\
\hline $\begin{array}{l}\text { Polypropylene-nitrogen-doped } \\
\text { mesoporous carbon modified separator }\end{array}$ & $3.95 \mathrm{mg} \cdot \mathrm{cm}^{-2}$ & $566 \mathrm{~mA} \cdot \mathrm{h} \cdot \mathrm{g}^{-1}$ (1200th, $\left.0.5 \mathrm{C}\right)$ & [203] \\
\hline $\begin{array}{l}\text { Nitrogen-doped hollow porous carbon } \\
\text { spheres modified separator }\end{array}$ & $1.6 \mathrm{mg} \cdot \mathrm{cm}^{-2}$ & $542 \mathrm{~mA} \cdot \mathrm{h} \cdot \mathrm{g}^{-1}(500 \mathrm{th}, 1 \mathrm{C})$ & [204] \\
\hline KB modified separator & $64 \%$ & $815 \mathrm{~mA} \cdot \mathrm{h} \cdot \mathrm{g}^{-1}(100 \mathrm{th}, 1 \mathrm{C})$ & [205] \\
\hline $\begin{array}{l}\text { Acetylene black-CNTs } \\
\text { modified separator }\end{array}$ & $1.5-2.0 \mathrm{mg} \cdot \mathrm{cm}^{-2}$ & $830 \mathrm{~mA} \cdot \mathrm{h} \cdot \mathrm{g}^{-1}$ (150th, 0.5C) & [206] \\
\hline GO modified separator & $1.2-1.4 \mathrm{mg} \cdot \mathrm{cm}^{-2}$ & $750 \mathrm{~mA} \cdot \mathrm{h} \cdot \mathrm{g}^{-1}(100 \mathrm{th}, 1 \mathrm{C})$ & [207] \\
\hline $\begin{array}{l}\text { Polypropylene/GO/Nafion } \\
\text { modified separator }\end{array}$ & $60 \%$ & $\sim 750 \mathrm{~mA} \cdot \mathrm{h} \cdot \mathrm{g}^{-1}$ (200th, 0.5C) & [208] \\
\hline $\begin{array}{l}\text { Polypropylene-cellular graphene } \\
\text { modified separator }\end{array}$ & $1.2 \mathrm{mg} \cdot \mathrm{cm}^{-2}$ & $800 \mathrm{~mA} \cdot \mathrm{h} \cdot \mathrm{g}^{-1}(250 \mathrm{th}, 0.2 \mathrm{C})$ & [209] \\
\hline $\begin{array}{l}\text { Polyvinylidene fluoride-carbon } \\
\text { modified separator }\end{array}$ & $7 \mathrm{mg} \cdot \mathrm{cm}^{-2}$ & $669 \mathrm{~mA} \cdot \mathrm{h} \cdot \mathrm{g}^{-1}$ (500th, 0.5C) & [210] \\
\hline MWCNTs@PEG modified separator & $60 \%$ & $490 \mathrm{~mA} \cdot \mathrm{h} \cdot \mathrm{g}^{-1}(500 \mathrm{th}, 1 \mathrm{C})$ & [211] \\
\hline
\end{tabular}

\section{Summary and Perspective}

Li-S battery technology has experienced a rapid development over the past 20 years. Researchers contribute tremendous efforts on explaining electrochemical mechanisms and refining the structure of the electrode materials and cell configuration for Li-S batteries. A variety of carbonaceous materials are being developed in order to improve electrochemical performances due to the unique physical and chemical properties (e.g., conductivity, morphologies and functional groups) of carbonaceous nanomaterials. In summary, there are mainly two directions in realising these goals.

\subsection{Materials Manipulation (Without Sacrificing Sulphur Content)}

In order to realise energy densities for $\mathrm{Li}-\mathrm{S}$ batteries that meet real-world needs, a high sulphur content in the carbon-S composites, a high ratio of carbon-S composites in the electrode, and a high areal coating weight of the carbon-S composites in the electrode are required. Thus, to make $\mathrm{Li}-\mathrm{S}$ batteries with satisfactory energy density, the electrode materials should be designed according to the following principles: firstly, the carbon host should have large enough pore volume to accommodate a high content of active materials, as well as a reasonable pore size to confine active materials and reduce their dissolution in the electrolytes; thus, porous carbon graphene and CNTs with high Brunauer, Emmett and Teller (BET) surface area, high pore volumes, and reasonable pore size are required. Secondly, improving the conductivity of the carbon host as much as possible ensures high utilization of sulphur, particularly when the electrode displays a high areal coating weight of active materials. Thirdly, electrodes should be fabricated in such a way so as to reduce the binders and conductive additives used, suggesting that binder-free $\mathrm{C}-\mathrm{S}$ composites are promising. Fourthly, due to polymers and metal oxides (such as polypyrrole [212], $\mathrm{PAN}$ [131], polyaniline [213], $\mathrm{TiO}_{2}$ [214], $\mathrm{MnO}_{2}$ [27], 
$\mathrm{MnO}$ [215], $\mathrm{ZnO}$ [25], MOFs [31], etc.), it was observed that the binding energy of these materials with sulphur species is stronger than pure carbon materials, but with a much lower conductivity compared with carbon materials. A hybrid nanostructure that combines the advantages of carbon and polymers/metal oxides are good candidates for the sulphur host for high energy density Li-S batteries. Last but not least, sustainable development and costs should also be taken into consideration. Therefore, biochar is an alternative candidate with great potential.

\subsection{Novel Cell Configurations}

Carbonaceous materials as an interlayer or conductive additive to modify the separator represent a novel practical cell configuration compared to the conventional Li-S cell. These outside-cathode modification methods are simple, yet extraordinarily effective in improving the cell performance because they can effectively trap/block polysulphides, reducing the parasitic reactions, and their ability to reactivate dead sulphur also helps to improve the cyclic stability of Li-S cells [171].

Although there are several challenges that restrict the commercialization of $\mathrm{Li}-\mathrm{S}$ batteries, the consistent progress via smart engineering of carbon structures for advanced $\mathrm{Li}-\mathrm{S}$ batteries have brought this technology closer to practical reality. There is no doubt that the Li-S battery is one of the most promising next-generation rechargeable batteries.

Acknowledgments: The authors acknowledge the financial support from the Australian Research Council.

Author Contributions: Xingxing Gu and Luke Hencz contributed to collecting and sorting the data; Xingxing Gu and Shanqing Zhang co-wrote the paper.

Conflicts of Interest: The authors declare no conflict of interest.

\section{References}

1. Wang, J.-G.; Xie, K.; Wei, B. Advanced engineering of nanostructured carbons for lithium-sulphur batteries. Nano Energy 2015, 15, 413-444. [CrossRef]

2. Yang, Z.; Zhang, J.; Kintner-Meyer, M.C.W.; Lu, X.; Choi, D.; Lemmon, J.P.; Liu, J. Electrochemical energy storage for green grid. Chem. Rev. 2011, 111, 3577-3613. [CrossRef] [PubMed]

3. Bruce, P.G.; Freunberger, S.A.; Hardwick, L.J; Tarascon, J.M. Li- $\mathrm{O}_{2}$ and Li-S batteries with high energy storage. Nat. Mater. 2012, 11, 19-29. [CrossRef] [PubMed]

4. Gu, X.X.; Zhang, S.Q.; Hou, Y.L. Graphene-based sulphur composites for energy storage and conversion in Li-S batteries. Chin. J. Chem. 2016, 34, 11-31. [CrossRef]

5. Yang, Y.; Zheng, G.; Cui, Y. Nanostructured sulphur cathodes. Chem. Soc. Rev. 2013, 42, 3018-3032. [CrossRef] [PubMed]

6. Song, M.K.; Cairns, E.J.; Zhang, Y. Lithium/sulphur batteries with high specific energy: Old challenges and new opportunities. Nanoscale 2013, 5, 2186-2204. [CrossRef] [PubMed]

7. Gu, X.; Tong, C.-J.; Lai, C.; Qiu, J.; Huang, X.; Yang, W.; Wen, B.; Liu, L.-M.; Hou, Y.; Zhang, S. Porous nitrogen and phosphorous dual doped graphene blocking layer for high performance Li-S batteries. J. Mater. Chem. A 2015, 3, 16670-16678. [CrossRef]

8. Scheers, J.; Fantini, S.; Johansson, P. A review of electrolytes for lithium-sulphur batteries. J. Power Sources 2014, 255, 204-218. [CrossRef]

9. Jayaprakash, N.; Shen, J.; Moganty, S.S.; Corona, A.; Archer, L.A. Porous hollow carbon@sulphur composites for high-power lithium-sulphur batteries. Angew. Chem. Int. Ed. 2011, 50, 5904-5908. [CrossRef] [PubMed]

10. Xiao, L.; Cao, Y.; Xiao, J.; Schwenzer, B.; Engelhard, M.H.; Saraf, L.V.; Nie, Z.; Exarhos, G.J.; Liu, J. A soft approach to encapsulate sulphur: polyaniline nanotubes for lithium-sulphur batteries with long cycle life. Adv. Mater. 2012, 24, 1176-1181. [CrossRef] [PubMed]

11. Zhang, J.; Xiang, J.; Dong, Z.; Liu, Y.; Wu, Y.; Xu, C.; Du, G. Biomass derived activated carbon with 3D connected architecture for rechargeable lithium-sulphur batteries. Electrochim. Acta 2014, 116, 146-151. [CrossRef]

12. Lin, Z.; Liang, C. Lithium-sulphur batteries: from liquid to solid cells. J. Mater. Chem. A 2015, 3, 936-958. [CrossRef] 
13. Mikhaylik, Y.V.; Akridge, J.R. Polysulphide shuttle study in the Li/S battery system. J. Electrochem. Soc. 2004, 151, A1969-A1976. [CrossRef]

14. Gu, X.; Wang, Y.; Lai, C.; Qiu, J.; Li, S.; Hou, Y.; Martens, W.; Mahmood, N.; Zhang, S. Microporous bamboo biochar for lithium-sulphur batteries. Nano Res. 2015, 8, 129-139. [CrossRef]

15. Rehman, S.; Gu, X.; Khan, K.; Mahmood, N.; Yang, W.; Huang, X.; Guo, S.; Hou, Y. 3D vertically aligned and interconnected porous carbon nanosheets as sulphur immobilizers for high performance lithium-sulphur batteries. Adv. Energy Mater. 2016, 6, 1502518-1502525. [CrossRef]

16. Xin, S.; Yin, Y.-X.; Wan, L.-J.; Guo, Y.-G. Encapsulation of sulphurin a hollow porous carbon substrate for superior Li-S batteries with long lifespan. Part. Part. Syst. Charact. 2013, 30, 321-325. [CrossRef]

17. Li, Z.; Jiang, Y.; Yuan, L.; Yi, Z.; Wu, C.; Liu, Y.; Strasser, P.; Huang, Y. A highly ordered meso@microporous carbon-supported sulphur@smaller sulphur core-shell structured cathode for Li-S batteries. ACS Nano 2014, 8, 9295-9303. [CrossRef] [PubMed]

18. Gu, X.; Lai, C.; Liu, F.; Yang, W.; Hou, Y.; Zhang, S. A conductive interwoven bamboo carbon fiber membrane for Li-S batteries. J. Mater. Chem. A 2015, 3, 9502-9509. [CrossRef]

19. Gu, X.; Tong, C.J.; Rehman, S.; Liu, L.M.; Hou, Y.; Zhang, S. Multifunctional nitrogen-doped loofah sponge carbon blocking layer for high-performance rechargeable lithium batteries. ACS Appl. Mater. Interface 2016, 8, 15991-16001. [CrossRef] [PubMed]

20. Fu, Y.; Manthiram, A. Enhanced cyclability of lithium-sulphur batteries by a polymer acid-doped polypyrrole mixed ionic-electronic conductor. Chem. Mater. 2012, 24, 3081-3087. [CrossRef]

21. Li, G.C.; Hu, J.J.; Li, G.R.; Ye, S.H.; Gao, X.P. Sulphur/activated-conductive carbon black composites as cathode materials for lithium/sulphur battery. J. Power Sources 2013, 240, 598-605. [CrossRef]

22. Su, Y.-S.; Manthiram, A. A facile in situ sulphur deposition route to obtain carbon-wrapped sulphur composite cathodes for lithium-sulphur batteries. Electrochim. Acta 2012, 77, 272-278. [CrossRef]

23. Wang, J.; Yang, J.; Xie, J.; Xu, N. A novel conductive polymer-sulphur composite cathode material for rechargeable lithium-sulphur batteries. Adv. Mater. 2002, 14, 963-965. [CrossRef]

24. Zhou, W.; Yu, Y.; Chen, H.; DiSalvo, F.J.; Abruna, H.D. Yolk-shell structure of polyaniline-coated sulphurfor lithium-sulphur batteries. J. Am. Chem. Soc. 2013, 135, 16736-16743. [CrossRef] [PubMed]

25. Gu, X.; Tong, C.-J.; Wen, B.; Liu, L.-M.; Lai, C.; Zhang, S. Ball-milling synthesis of ZnO@sulphur/carbon nanotubes and $\mathrm{Ni}(\mathrm{OH})_{2} @$ sulphur/carbon nanotubes composites for high-performance lithium-sulphur batteries. Electrochim. Acta 2016, 196, 369-376. [CrossRef]

26. Liang, X.; Nazar, L.F. In situ reactive assembly of scalable core-shell sulphur- $\mathrm{MnO}_{2}$ composite cathodes. ACS Nano 2016, 10, 4192-4198. [CrossRef] [PubMed]

27. Sun, W.; Ou, X.; Yue, X.; Yang, Y.; Wang, Z.; Rooney, D.; Sun, K. A simply effective double-coating cathode with $\mathrm{MnO}_{2}$ nanosheets/graphene as functionalized interlayer for high performance lithium-sulphur batteries. Electrochim. Acta 2016, 207, 198-206. [CrossRef]

28. Yu, M.; Ma, J.; Song, H.; Wang, A.; Tian, F.; Wang, Y.; Qiu, H.; Wang, R. Atomic layer deposited $\mathrm{TiO}_{2}$ on a nitrogen-doped graphene/sulphur electrode for high performance lithium-sulphur batteries. Energy Environ. Sci. 2016, 9, 1495-1503. [CrossRef]

29. Demir-Cakan, R.; Morcrette, M.; Nouar, F.; Davoisne, C.; Devic, T.; Gonbeau, D.; Dominko, R.; Serre, C.; Ferey, G.; Tarascon, J.M. Cathode composites for Li-S batteries via the use of oxygenated porous architectures. J. Am. Chem. Soc. 2011, 133, 16154-16160. [CrossRef] [PubMed]

30. Tao, X.; Chen, F.; Xia, Y.; Huang, H.; Gan, Y.; Chen, X.; Zhang, W. Decoration of sulphur with porous metal nanostructures: An alternative strategy for improving the cyclability of sulphur cathode materials for advanced lithium-sulphur batteries. Chem. Commun. 2013, 49, 4513-4515. [CrossRef] [PubMed]

31. Zheng, J.; Tian, J.; Wu, D.; Gu, M.; Xu, W.; Wang, C.; Gao, F.; Engelhard, M.H.; Zhang, J.G.; Liu, J.; et al. Lewis acid-base interactions between polysulphides and metal organic framework in lithium sulphur batteries. Nano Lett. 2014, 14, 2345-2352. [CrossRef] [PubMed]

32. Demir-Cakan, R.; Morcrette, M.; Gueguen, A.; Dedryvere, R.; Tarascon, J.M. Li-S batteries: Simple approaches for superior performance. Energy Environ. Sci. 2013, 6, 176-182. [CrossRef]

33. Li, G.; Ling, M.; Ye, Y.; Li, Z.; Guo, J.; Yao, Y.; Zhu, J.; Lin, Z.; Zhang, S. Acacia senegal-inspired bifunctional binder for longevity of lithium-sulfur batteries. Adv. Energy Mater. 2015, 5. [CrossRef]

34. Lin, Z.; Liu, Z.; Fu, W.; Dudney, N.J.; Liang, C. Phosphorous pentasulfide as a novel additive for high-performance lithium-sulphur batteries. Adv. Funct. Mater. 2013, 23, 1064-1069. [CrossRef] 
35. Suo, L.; Hu, Y.S.; Li, H.; Armand, M.; Chen, L. A new class of solvent-in-salt electrolyte for high-energy rechargeable metallic lithium batteries. Nat. Commun. 2013, 4, 1481-1489. [CrossRef] [PubMed]

36. Zhang, Z.; Bao, W.; Lu, H.; Jia, M.; Xie, K.; Lai, Y.; Li, J. Water-soluble polyacrylic acid as a binder for sulphur cathode in lithium-sulphur battery. ECS Electrochem. Lett. 2012, 1, A34-A37. [CrossRef]

37. He, B.; Li, W.C.; Yang, C.; Wang, S.Q.; Lu, A.H. Incorporating sulphur inside the pores of carbons for advanced lithium-sulphur batteries: An electrolysis approach. ACS Nano 2016, 10, 1633-1639. [CrossRef] [PubMed]

38. Xi, K.; Cao, S.; Peng, X.; Ducati, C.; Kumar, R.V.; Cheetham, A.K. Carbon with hierarchical pores from carbonized metal-organic frameworks for lithium sulphur batteries. Chem. Commun. 2013, 49, 2192-2194. [CrossRef] [PubMed]

39. Chen, H.; Wei, Y.; Wang, J.; Qiao, W.; Ling, L.; Long, D. Controllable nitrogen doping of high-surface-area microporous carbons synthesized from an organic-inorganic sol-gel approach for Li-S cathodes. ACS Appl. Mater. Interface 2015, 7, 21188-21197. [CrossRef] [PubMed]

40. Li, Z.; Yuan, L.; Yi, Z.; Sun, Y.; Liu, Y.; Jiang, Y.; Shen, Y.; Xin, Y.; Zhang, Z.; Huang, Y. Insight into the electrode mechanism in lithium-sulphur batteries with ordered microporous carbon confined sulphur as the cathode. Adv. Energy Mater. 2014, 4, 1301473-1301480. [CrossRef]

41. Rao, M.; Li, W.; Cairns, E.J. Porous carbon-sulfur composite cathode for lithium/sulfur cells. Electrochem. Commun. 2012, 17, 1-5. [CrossRef]

42. Ryu, H.S.; Park, J.W.; Park, J.; Ahn, J.-P.; Kim, K.-W.; Ahn, J.-H.; Nam, T.-H.; Wang, G.; Ahn, H.-J. High capacity cathode materials for Li-S batteries. J. Mater. Chem. A 2013, 1, 1573-1578. [CrossRef]

43. Xu, G.L.; Xu, Y.F.; Fang, J.C.; Peng, X.X.; Fu, F.; Huang, L.; Li, J.T.; Sun, S.G. Porous graphitic carbon loading ultra high sulphuras high-performance ccathode of rechargeable lithium-sulphur batteries. ACS Appl. Mater. Interface 2013, 5, 10782-10793. [CrossRef] [PubMed]

44. Xu, Y.; Wen, Y.; Zhu, Y.; Gaskell, K.; Cychosz, K.A.; Eichhorn, B.; Xu, K.; Wang, C. Confined sulphur in microporous carbon renders superior cycling stability in Li/S batteries. Adv. Funct. Mater. 2015, 25, 4312-4320. [CrossRef]

45. Zhang, B.; Qin, X.; Li, G.R.; Gao, X.P. Enhancement of long stability of sulphur cathode by encapsulating sulphur into micropores of carbon spheres. Energy Environ. Sci. 2010, 3, 1531-1537. [CrossRef]

46. Zhang, W.; Qiao, D.; Pan, J.; Cao, Y.; Yang, H.; Ai, X. A Li ${ }^{+}$-conductive microporous carbon-sulphur composite for Li-S batteries. Electrochim. Acta 2013, 87, 497-502. [CrossRef]

47. Zhou, L.; Huang, T.; Yu, A. Three-dimensional flower-shaped activated porous carbon/sulphur composites as cathode materials for lithium-sulphur batteries. ACS Sustain. Chem. Eng. 2014, 2, 2442-2447. [CrossRef]

48. Wang, J.L.; Yang, J.; Xie, J.Y.; Xu, N.X.; Li, Y. Sulphur-carbon nano-composite as cathode for rechargeable lithium battery based on gel electrolyte. Electrochem. Commun. 2002, 4, 499-502. [CrossRef]

49. Wang, J.; Chew, S.Y.; Zhao, Z.W.; Ashraf, S.; Wexler, D.; Chen, J.; Ng, S.H.; Chou, S.L.; Liu, H.K. Sulphur-mesoporous carbon composites in conjunction with a novel ionic liquid electrolyte for lithium rechargeable batteries. Carbon 2008, 46, 229-235. [CrossRef]

50. Ji, X.; Lee, K.T.; Nazar, L.F. A highly ordered nanostructured carbon-sulphur cathode for lithium-sulphur batteries. Nat. Mater. 2009, 8, 500-506. [CrossRef] [PubMed]

51. Fang, X.; Weng, W.; Ren, J.; Peng, H. A cable-shaped lithium sulphur battery. Adv. Mater. 2016, 28, 491-496. [CrossRef] [PubMed]

52. Ji, X.; Evers, S.; Black, R.; Nazar, L.F. Stabilizing lithium-sulphur cathodes using polysulphide reservoirs. Nat. Commun. 2011, 2, 325-331. [CrossRef] [PubMed]

53. Kim, J.H.; Kim, T.; Jeong, Y.C.; Lee, K.; Park, K.T.; Yang, S.J.; Park, C.R. Stabilization of insoluble discharge products by facile aniline modification for high performance Li-S batteries. Adv. Energy Mater. 2015, 5, 1500268-1500277. [CrossRef]

54. Li, Q.; Zhou, C.; Ji, Z.; Han, B.; Feng, L.; Wu, J. High-performance lithium/sulphur batteries by decorating CMK-3/S cathodes with DNA. J. Mater. Chem. A 2015, 3, 7241-7247. [CrossRef]

55. Nagao, M.; Imade, Y.; Narisawa, H.; Kobayashi, T.; Watanabe, R.; Yokoi, T.; Tatsumi, T.; Kanno, R. All-solid-state Li-sulphur batteries with mesoporous electrode and thio-LISICON solid electrolyte. J. Power Sources 2013, 222, 237-242. [CrossRef]

56. Zhao, X.Y.; Tu, J.P.; Lu, Y.; Cai, J.B.; Zhang, Y.J.; Wang, X.L.; Gu, C.D. Graphene-coated mesoporous carbon/sulphur cathode with enhanced cycling stability. Electrochim. Acta 2013, 113, 256-262. [CrossRef] 
57. Zhou, X.; Xie, J.; Yang, J.; Zou, Y.; Tang, J.; Wang, S.; Ma, L.; Liao, Q. Improving the performance of lithium-sulphur batteries by graphene coating. J. Power Sources 2013, 243, 993-1000. [CrossRef]

58. Chen, S.-R.; Zhai, Y.-P.; Xu, G.-L.; Jiang, Y.-X.; Zhao, D.-Y.; Li, J.-T.; Huang, L.; Sun, S.-G. Ordered mesoporous carbon/sulphur nanocomposite of high performances as cathode for lithium-sulphur battery. Electrochim. Acta 2011, 56, 9549-9555. [CrossRef]

59. He, G.; Ji, X.; Nazar, L. High “C" rate Li-S cathodes: Sulphur imbibed bimodal porous carbons. Energy Environ. Sci. 2011, 4, 2878-2883. [CrossRef]

60. Hu, W.; Zhang, H.; Wang, M.; Zhang, H.; Qu, C. Tri-modal mesoporous carbon/sulphur nanocomposite for high performance Li-S battery. Electrochim. Acta 2016, 190, 322-328. [CrossRef]

61. Li, J.; Qin, F.; Zhang, L.; Zhang, K.; Li, Q.; Lai, Y.; Zhang, Z.; Fang, J. Mesoporous carbon from biomass: One-pot synthesis and application for Li-S batteries. J. Mater. Chem. A 2014, 2, 13916-13922. [CrossRef]

62. Li, L.-Y.; Chen, Y.-X.; Zhong, B.-H. Synthesis and electrochemical performance of a simple and low-cost sulphur/porous carbon composite cathode for rechargeable lithium sulphur battery. Compos. Part A Appl. Sci. Manuf. 2014, 62, 26-31. [CrossRef]

63. Li, X.; Cao, Y.; Qi, W.; Saraf, L.V.; Xiao, J.; Nie, Z.; Mietek, J.; Zhang, J.-G.; Schwenzer, B.; Liu, J. Optimization of mesoporous carbon structures for lithium-sulphur battery applications. J. Mater. Chem. 2011, 21, 16603-16610. [CrossRef]

64. Liang, X.; Wen, Z.; Liu, Y.; Zhang, H.; Huang, L.; Jin, J. Highly dispersed sulphurin ordered mesoporous carbon sphere as a composite cathode for rechargeable polymer Li/S battery. J. Power Sources 2011, 196, 3655-3658. [CrossRef]

65. Liu, J.; Yang, T.; Wang, D.W.; Lu, G.Q.; Zhao, D.; Qiao, S.Z. A facile soft-template synthesis of mesoporous polymeric and carbonaceous nanospheres. Nat. Commun. 2013, 4, 2798-2804. [CrossRef]

66. Park, M.S.; Jeong, B.O.; Kim, T.J.; Kim, S.; Kim, K.J.; Yu, J.S.; Jung, Y.; Kim, Y.J. Disordered mesoporous carbon as polysulphide reservoir for improved cyclic performance of lithium-sulphur batteries. Carbon 2014, 68, 265-272. [CrossRef]

67. Schuster, J.; He, G.; Mandlmeier, B.; Yim, T.; Lee, K.T.; Bein, T.; Nazar, L.F. Spherical ordered mesoporous carbon nanoparticles with high porosity for lithium-sulphur batteries. Angew. Chem. Int. Ed. 2012, 51, 3591-3595. [CrossRef] [PubMed]

68. See, K.A.; Jun, Y.S.; Gerbec, J.A.; Sprafke, J.K.; Wudl, F.; Stucky, G.D.; Seshadri, R. Sulphur-functionalized mesoporous carbons as sulphur hosts in Li-S batteries: Increasing the affinity of polysulphide intermediates to enhance performance. ACS Appl. Mater. Interface 2014, 6, 10908-10916. [CrossRef] [PubMed]

69. Sohn, H.; Gordin, M.L.; Xu, T.; Chen, S.; Lv, D.; Song, J.; Manivannan, A.; Wang, D. Porous spherical carbon/sulphur nanocomposites by aerosol-assisted synthesis: The effect of pore structure and morphology on their electrochemical performance as lithium/sulphur battery cathodes. ACS Appl. Mater. Interface 2014, 6, 7596-7606. [CrossRef] [PubMed]

70. Song, J.; Xu, T.; Gordin, M.L.; Zhu, P.; Lv, D.; Jiang, Y.-B.; Chen, Y.; Duan, Y.; Wang, D. Nitrogen-doped mesoporous carbon promoted chemical adsorption of sulphur and fabrication of high-areal-capacity sulphur cathode with exceptional cycling stability for lithium-sulphur batteries. Adv. Funct. Mater. 2014, 24, 1243-1250. [CrossRef]

71. Sun, X.G.; Wang, X.; Mayes, R.T.; Dai, S. Lithium-sulphur batteries based on nitrogen-doped carbon and an ionic-liquid electrolyte. ChemSusChem 2012, 5, 2079-2085. [CrossRef] [PubMed]

72. Tao, X.; Chen, X.; Xia, Y.; Huang, H.; Gan, Y.; Wu, R.; Chen, F.; Zhang, W. Highly mesoporous carbon foams synthesized by a facile, cost-effective and template-free Pechini method for advanced lithium-sulphur batteries. J. Mater. Chem. A 2013, 1, 3295-3301. [CrossRef]

73. Wei, Y.; Tao, Y.; Zhang, C.; Wang, J.; Qiao, W.; Ling, L.; Long, D. Layered carbide-derived carbon with hierarchically porous structure for high rate lithium-sulphur batteries. Electrochim. Acta 2016, 188, 385-392. [CrossRef]

74. Weng, W.; Pol, V.G.; Amine, K. Ultrasound assisted design of sulphur/carbon cathodes with partially fluorinated ether electrolytes for highly efficient Li/S batteries. Adv. Mater. 2013, 25, 1608-1615. [CrossRef] [PubMed]

75. Xu, M.; Jia, M.; Mao, C.; Liu, S.; Bao, S.; Jiang, J.; Liu, Y.; Lu, Z. Aspergillus flavus conidia-derived carbon/sulfur composite as a cathode material for high performance lithium-sulfur battery. Sci. Rep. 2016, 6, 18739-18747. [CrossRef] [PubMed] 
76. Choudhury, S.; Agrawal, M.; Formanek, P.; Jehnichen, D.; Fischer, D.; Krause, B.; Albrecht, V.; Stamm, M.; Ionov, L. Nanoporous cathodes for high-energy Li-S batteries from gyroid block copolymer templates. ACS Nano 2015, 9, 6147-6157. [CrossRef] [PubMed]

77. Ding, B.; Yuan, C.; Shen, L.; Xu, G.; Nie, P.; Zhang, X. Encapsulating sulphur into hierarchically ordered porous carbon as a high-performance cathode for lithium-sulphur batteries. Chem. Eur. J. 2013, 19, 1013-1019. [CrossRef] [PubMed]

78. Wang, D.-W.; Zeng, Q.; Zhou, G.; Yin, L.; Li, F.; Cheng, H.-M.; Gentle, I.R.; Lu, G.Q.M. Carbon-sulphur composites for Li-S batteries: Status and prospects. J. Mater. Chem. A 2013, 1, 9382-9394. [CrossRef]

79. Lai, C.; Gao, X.P.; Zhang, B.; Yan, T.Y.; Zhou, Z. Synthesis and electrochemical performance of sulphur/highly porous carbon composites. J. Phys. Chem. C 2009, 113, 4712-4716. [CrossRef]

80. Liang, C.; Dudney, N.J.; Howe, J.Y. Hierarchically structured sulphur/carbon nanocomposite material for high-energy lithium battery. Chem. Mater. 2009, 21, 4724-4730. [CrossRef]

81. Qu, Y.; Zhang, Z.; Zhang, X.; Ren, G.; Wang, X.; Lai, Y.; Liu, Y.; Li, J. Synthesis of hierarchical porous honeycomb carbon for lithium-sulphur battery cathode with high rate capability and long cycling stability. Electrochim. Acta 2014, 137, 439-446. [CrossRef]

82. Yu, L.; Brun, N.; Sakaushi, K.; Eckert, J.; Titirici, M.M. Hydrothermal nanocasting: Synthesis of hierarchically porous carbon monoliths and their application in lithium-sulphur batteries. Carbon 2013, 61, 245-253. [CrossRef]

83. Zhao, C.; Liu, L.; Zhao, H.; Krall, A.; Wen, Z.; Chen, J.; Hurley, P.; Jiang, J.; Li, Y. Sulphur-infiltrated porous carbon microspheres with controllable multi-modal pore size distribution for high energy lithium-sulphur batteries. Nanoscale 2014, 6, 882-888. [CrossRef] [PubMed]

84. Xu, G.; Ding, B.; Nie, P.; Shen, L.; Dou, H.; Zhang, X. Hierarchically porous carbon encapsulating sulphur as a superior cathode material for high performance lithium-sulphur batteries. ACS Appl. Mater. Interface 2014, 6, 194-199. [CrossRef] [PubMed]

85. Wang, X.; Fang, X.; Guo, X.; Wang, Z.; Chen, L. Sulphur in hierarchically pore-structured carbon pillars as cathode material for lithium-sulphur batteries. Electrochim. Acta 2013, 97, 238-243. [CrossRef]

86. Chen, S.; Sun, B.; Xie, X.; Mondal, A.K.; Huang, X.; Wang, G. Multi-chambered micro/mesoporous carbon nanocubes as new polysulphides reserviors for lithium-sulphur batteries with long cycle life. Nano Energy 2015, 16, 268-280. [CrossRef]

87. Brückner, J.; Thieme, S.; Böttger-Hiller, F.; Bauer, I.; Grossmann, H.T.; Strubel, P.; Althues, H.; Spange, S.; Kaskel, S. Carbon-based anodes for lithium sulphur full cells with high cycle stability. Adv. Funct. Mater. 2013, 24, 1284-1289. [CrossRef]

88. Brun, N.; Sakaushi, K.; Eckert, J.; Titirici, M.M. Carbohydrate-derived nanoarchitectures: On a synergistic effect toward an improved performance in lithium-sulphur batteries. ACS Sustain. Chem. Eng. 2014, 2, 126-129. [CrossRef]

89. Brun, N.; Sakaushi, K.; Yu, L.; Giebeler, L.; Eckert, J.; Titirici, M.M. Hydrothermal carbon-based nanostructured hollow spheres as electrode materials for high-power lithium-sulphur batteries. Phys. Chem. Chem. Phys. 2013, 15, 6080-6087. [CrossRef] [PubMed]

90. Zhang, C.; Hao, B.; Yuan, C.; Guo, Z.; Lou, X.D. Confining sulphur in double-shelled hollow carbon spheres for lithium-sulphur batteries. Angew. Chem. Int. Ed. 2012, 124, 9730-9733. [CrossRef]

91. He, G.; Evers, S.; Liang, X.; Cuisinier, M.; Garsuch, A.; Nazar, L.F. Tailoring porosity in carbon nanospheres for lithium-sulphur battery cathodes. ACS Nano 2013, 7, 10920-10930. [CrossRef] [PubMed]

92. Hu, W.; Zhang, H.; Zhang, Y.; Wang, M.; Qu, C.; Yi, J. Biomineralization-induced self-assembly of porous hollow carbon nanocapsule monoliths and their application in Li-S batteries. Chem. Commun. 2015, 51, 1085-1088. [CrossRef] [PubMed]

93. Li, D.; Han, F.; Wang, S.; Cheng, F.; Sun, Q.; Li, W.C. High sulphur loading cathodes fabricated using peapodlike, large pore volume mesoporous carbon for lithium-sulphur battery. ACS Appl. Mater. Interface 2013, 5, 2208-2213. [CrossRef] [PubMed]

94. Shin, E.S.; Kim, M.S.; Cho, W.I.; Oh, S.H. Sulphur/graphitic hollow carbon sphere nano-composite as a cathode material for high-power lithium-sulphur battery. Nanoscale Res. Lett. 2013, 8, 343-350. [CrossRef] [PubMed]

95. Zhang, K.; Zhao, Q.; Tao, Z.; Chen, J. Composite of sulphur impregnated in porous hollow carbon spheres as the Cathode of Li-S batteries with high performance. Nano Res. 2012, 6, 38-46. [CrossRef] 
96. Yao, H.; Zheng, G.; Li, W.; McDowell, M.T.; Seh, Z.; Liu, N.; Lu, Z.; Cui, Y. Crab shells as sustainable templates from nature for nanostructured battery electrodes. Nano Lett. 2013, 13, 3385-3390. [CrossRef] [PubMed]

97. Wei, S.; Zhang, H.; Huang, Y.; Wang, W.; Xia, Y.; Yu, Z. Pig bone derived hierarchical porous carbon and its enhanced cycling performance of lithium-sulphur batteries. Energy Environ. Sci. 2011, 4, 736-740. [CrossRef]

98. Zhang, J.; Cai, Y.; Zhong, Q.; Lai, D.; Yao, J. Porous nitrogen-doped carbon derived from silk fibroin protein encapsulating sulphur as a superior cathode material for high-performance lithium-sulphur batteries. Nanoscale 2015, 7, 17791-17797. [CrossRef] [PubMed]

99. Zhao, S.; Li, C.; Wang, W.; Zhang, H.; Gao, M.; Xiong, X.; Wang, A.; Yuan, K.; Huang, Y.; Wang, F. A novel porous nanocomposite of sulphur/carbon obtained from fish scales for lithium-sulphur batteries. J. Mater. Chem. A 2013, 1, 3334-3339. [CrossRef]

100. Chung, S.-H.; Manthiram, A. Eggshell membrane-derived polysulphide absorbents for highly stable and reversible lithium-sulphur cells. ACS Sustain. Chem. Eng. 2014, 2, 2248-2252. [CrossRef]

101. Tao, X.Y.; Zhang, J.T.; Xia, Y.; Huang, H.; Du, J.; Xiao, H.; Zhang, W.K.; Gan, Y.P. Bio-inspired fabrication of carbon nanotiles for high performance cathode of Li-S batteries. J. Mater. Chem. A 2014, 2, 2290-2296. [CrossRef]

102. Zhang, Y.; Zhao, Y.; Konarov, A.; Li, Z.; Chen, P. Effect of mesoporous carbon microtube prepared by carbonizing the poplar catkin on sulphur cathode performance in Li/S batteries. J. Alloy. Compd. 2015, 619, 298-302. [CrossRef]

103. Yang, S.T.; Yan, C.; Cao, Z.-X.; Shi, M.-J.; Li, Y.-L.; Yin, Y.-H. Preparation of hierarchical porous carbon/sulphur composite based on lotus-leaves and its property for Li-S batteries. J. Inorg. Mater. 2016, 31, 135-140.

104. Pang, Q.; Tang, J.; Huang, H.; Liang, X.; Hart, C.; Tam, K.C.; Nazar, L.F. A nitrogen and sulphur dual-doped carbon derived from polyrhodanine@cellulose for advanced lithium-sulphur batteries. Adv. Mater. 2015, 27, 6021-6028. [CrossRef] [PubMed]

105. Schipper, F.; Vizintin, A.; Ren, J.; Dominko, R.; Fellinger, T.P. Biomass-derived heteroatom-doped carbon aerogels from a salt melt sol-gel synthesis and their performance in Li-S batteries. ChemSusChem 2015, 8, 3077-3083. [CrossRef] [PubMed]

106. Rao, M.; Song, X.; Cairns, E.J. Nano-carbon/sulphur composite cathode materials with carbon nanofiber as electrical conductor for advanced secondary lithium/sulphur cells. J. Power Sources 2012, 205, 474-478. [CrossRef]

107. Choi, Y.-J.; Kim, K.-W.; Ahn, H.-J.; Ahn, J.-H. Improvement of cycle property of sulphur electrode for lithium/sulphur battery. J. Alloy. Compd. 2008, 449, 313-316. [CrossRef]

108. Elazari, R.; Salitra, G.; Garsuch, A.; Panchenko, A.; Aurbach, D. Sulphur-impregnated activated carbon fiber cloth as a binder-free cathode for rechargeable Li-S batteries. Adv. Mater. 2011, 23, 5641-5644. [CrossRef] [PubMed]

109. Ji, L.; Rao, M.; Aloni, S.; Wang, L.; Cairns, E.J.; Zhang, Y. Porous carbon nanofiber-sulfur composite electrodes for lithium/sulfur cells. Energy Environ. Sci. 2011, 4, 5053-5059. [CrossRef]

110. Zheng, G.; Yang, Y.; Cha, J.J.; Hong, S.S.; Cui, Y. Hollow carbon nanofiber-encapsulated sulphur cathodes for high specific capacity rechargeable lithium batteries. Nano Lett. 2011, 11, 4462-4467. [CrossRef] [PubMed]

111. Zheng, G.; Zhang, Q.; Cha, J.J.; Yang, Y.; Li, W.; Seh, Z.W.; Cui, Y. Amphiphilic surface modification of hollow carbon nanofibers for improved cycle life of lithium sulphur batteries. Nano Lett. 2013, 13, 1265-1270. [CrossRef] [PubMed]

112. Deng, Z.; Zhang, Z.; Lai, Y.; Liu, J.; Liu, Y.; Li, J. A sulphur-carbon composite for lithium/sulphur battery based on activated vapor-grown carbon fiber. Solid State Ion. 2013, 238, 44-49. [CrossRef]

113. Wu, Y.; Gao, M.; Li, X.; Liu, Y.; Pan, H. Preparation of mesohollow and microporous carbon nanofiber and its application in cathode material for lithium-sulphur batteries. J. Alloy. Compd. 2014, 608, 220-228. [CrossRef]

114. Yang, J.; Xie, J.; Zhou, X.; Zou, Y.; Tang, J.; Wang, S.; Chen, F.; Wang, L. Functionalized N-doped porous carbon nanofiber webs for a lithium-sulphur battery with high capacity and rate performance. J. Phys. Chem. C 2014, 118, 1800-1807. [CrossRef]

115. Han, S.-C.; Song, M.-S.; Lee, H.; Kim, H.-S.; Ahn, H.-J.; Lee, J.-Y. Effect of multiwalled carbon nanotubes on electrochemical properties of lithium/sulphur rechargeable batteries. J. Electrochem. Soc. 2003, 150, A889-A893. [CrossRef]

116. Zheng, W.; Liu, Y.W.; Hu, X.G.; Zhang, C.F. Novel nanosized adsorbing sulphur composite cathode materials for the advanced secondary lithium batteries. Electrochim. Acta 2006, 51, 1330-1335. [CrossRef] 
117. Yuan, L.; Yuan, H.; Qiu, X.; Chen, L.; Zhu, W. Improvement of cycle property of sulphur-coated multi-walled carbon nanotubes composite cathode for lithium/sulphur batteries. J. Power Sources 2009, 189, 1141-1146. [CrossRef]

118. Chen, J.-J.; Jia, X.; She, Q.-J.; Wang, C.; Zhang, Q.; Zheng, M.-S.; Dong, Q.-F. The preparation of nano-sulphur/MWCNTs and its electrochemical performance. Electrochim. Acta 2010, 55, 8062-8066.

119. Ahn, W.; Kim, K.-B.; Jung, K.-N.; Shin, K.-H.; Jin, C.-S. Synthesis and electrochemical properties of a sulphur-multi walled carbon nanotubes composite as a cathode material for lithium sulphur batteries. J. Power Sources 2012, 202, 394-399. [CrossRef]

120. Geng, X.; Rao, M.; Li, X.; Li, W. Highly dispersed sulphur in multi-walled carbon nanotubes for lithium/sulphur battery. J. Solid State Electrochem. 2012, 17, 987-992. [CrossRef]

121. Guo, J.; Xu, Y.; Wang, C. Sulfur-impregnated disordered carbon nanotubes cathode for lithium-sulfur batteries. Nano Lett. 2011, 11, 4288-4294. [CrossRef] [PubMed]

122. Ma, X.Z.; Jin, B.; Xin, P.M.; Wang, H.H. Multiwalled carbon nanotubes-sulphur composites with enhanced electrochemical performance for lithium/sulphur batteries. Appl. Surf. Sci. 2014, 307, 346-350. [CrossRef]

123. Wang, L.; Zhao, Y.; Thomas, M.L.; Byon, H.R. In situ synthesis of bipyramidal sulphur with 3D carbon nanotube framework for lithium-sulphur batteries. Adv. Funct. Mater. 2014, 24, 2248-2252. [CrossRef]

124. Cheng, X.-B.; Huang, J.-Q.; Zhang, Q.; Peng, H.-J.; Zhao, M.-Q.; Wei, F. Aligned carbon nanotube/sulphur composite cathodes with high sulphur content for lithium-sulphur batteries. Nano Energy 2014, 4, 65-72. [CrossRef]

125. Jin, K.; Zhou, X.; Zhang, L.; Xin, X.; Wang, G.; Liu, Z. Sulfur/carbon nanotube composite film as a flexible cathode for lithium-sulfur batteries. J. Phys. Chem. C 2013, 117, 21112-21119. [CrossRef]

126. Moon, S.; Jung, Y.H.; Jung, W.K.; Jung, D.S.; Choi, J.W.; Kim, D.K. Encapsulated monoclinic sulphur for stable cycling of Li-S rechargeable batteries. Adv. Mater. 2013, 25, 6547-6553. [CrossRef] [PubMed]

127. Hagen, M.; Dörfler, S.; Althues, H.; Tübke, J.; Hoffmann, M.J.; Kaskel, S.; Pinkwart, K. Lithium-sulphur batteries-binder free carbon nanotubes electrode examined with various electrolytes. J. Power Sources 2012, 213, 239-248. [CrossRef]

128. Dorfler, S.; Hagen, M.; Althues, H.; Tubke, J.; Kaskel, S.; Hoffmann, M.J. High capacity vertical aligned carbon nanotube/sulfur composite cathodes for lithium-sulfur batteries. Chem. Commun. 2012, 48, 4097-4099. [CrossRef] [PubMed]

129. Huang, J.-Q.; Zhang, Q.; Zhang, S.-M.; Liu, X.-F.; Zhu, W.; Qian, W.-Z.; Wei, F. Aligned sulfur-coated carbon nanotubes with a polyethylene glycol barrier at one end for use as a high efficiency sulfur cathode. Carbon 2013, 58, 99-106. [CrossRef]

130. Wang, L.; Dong, Z.; Wang, D.; Zhang, F.; Jin, J. Covalent bond glued sulphur nanosheet-based cathode integration for long-cycle-life Li-S batteries. Nano Lett. 2013, 13, 6244-6250. [CrossRef] [PubMed]

131. Yin, L.C.; Wang, J.L.; Yang, J.; Nuli, Y.N. A novel pyrolyzed polyacrylonitrile-sulphur@MWCNT composite cathode material for high-rate rechargeable lithium/sulfur batteries. J. Mater. Chem. 2011, 21, 6807-6810. [CrossRef]

132. Bao, W.; Zhang, Z.; Zhou, C.; Lai, Y.; Li, J. Multi-walled carbon nanotubes @ mesoporous carbon hybrid nanocomposites from carbonized multi-walled carbon nanotubes @ metal-organic framework for lithium sulfur battery. J. Power Sources 2014, 248, 570-576. [CrossRef]

133. Chen, R.; Zhao, T.; Lu, J.; Wu, F.; Li, L.; Chen, J.; Tan, G.; Ye, Y.; Amine, K. Graphene-based three-dimensional hierarchical sandwich-type architecture for high-performance Li/S batteries. Nano Lett. 2013, 13, 4642-4649. [CrossRef] [PubMed]

134. Deng, Z.-F.; Zhang, Z.-A.; Lu, H.; Lai, Y.-Q.; Liu, J.; Li, J.; Liu, Y.-X. Vapor-grown carbon fibers enhanced sulphur-multi walled carbon nanotubes composite cathode for lithium/sulphur batteries. Trans. Nonferrous Met. Soc. 2014, 24, 158-163. [CrossRef]

135. Wei, W.; Wang, J.; Zhou, L.; Yang, J.; Schumann, B.; NuLi, Y. CNT enhanced sulfur composite cathode material for high rate lithium battery. Electrochem. Commun. 2011, 13, 399-402. [CrossRef]

136. Xie, J.; Yang, J.; Zhou, X.; Zou, Y.; Tang, J.; Wang, S.; Chen, F. Preparation of three-dimensional hybrid nanostructure-encapsulated sulphur cathode for high-rate lithium sulphur batteries. J. Power Sources 2014, 253, 55-63. [CrossRef] 
137. Xu, T.; Song, J.; Gordin, M.L.; Sohn, H.; Yu, Z.; Chen, S.; Wang, D. Mesoporous carbon-carbon nanotube-sulfur composite microspheres for high-areal-capacity lithium-sulfur battery cathodes. ACS Appl. Mater. Interface 2013, 5, 11355-11362. [CrossRef] [PubMed]

138. Chen, J.J.; Zhang, Q.; Shi, Y.N.; Qin, L.L.; Cao, Y.; Zheng, M.S.; Dong, Q.F. A Hierarchical architecture S/MWCNT nanomicrosphere with large pores for lithium sulphur batteries. Phys. Chem. Chem. Phys. 2012, 14, 5376-5382. [CrossRef] [PubMed]

139. Liu, X.; Zhang, Q.; Huang, J.; Zhang, S.; Peng, H.; Wei, F. Hierarchical nanostructured composite cathode with carbon nanotubes as conductive scaffold for lithium-sulfur batteries. J. Energy Chem. 2013, 22, 341-346. [CrossRef]

140. Xu, G.; Ding, B.; Nie, P.; Shen, L.; Wang, J.; Zhang, X. Porous nitrogen-doped carbon nanotubes derived from tubular polypyrrole for energy-storage applications. Chem. Eur. J. 2013, 19, 12306-12312. [CrossRef] [PubMed]

141. Li, Z.; Huang, Y.; Yuan, L.; Hao, Z.; Huang, Y. Status and prospects in sulfur-carbon composites as cathode materials for rechargeable lithium-sulfur batteries. Carbon 2015, 92, 41-63. [CrossRef]

142. Ji, L.; Rao, M.; Zheng, H.; Zhang, L.; Li, Y.; Duan, W.; Guo, J.; Cairns, E.J.; Zhang, Y. Graphene oxide as a sulphur immobilizer in high performance lithium/sulphur cells. J. Am. Chem. Soc. 2011, 133, 18522-18525. [CrossRef] [PubMed]

143. Wu, H.; Huang, Y.; Zong, M.; Ding, X.; Ding, J.; Sun, X. Electrostatic self-assembly of graphene oxide wrapped sulfur particles for lithium-sulfur batteries. Mater. Res. Bull. 2015, 64, 12-16. [CrossRef]

144. Xiao, M.; Huang, M.; Zeng, S.; Han, D.; Wang, S.; Sun, L.; Meng, Y. Sulfur@graphene oxide core-shell particles as a rechargeable lithium-sulfur battery cathode material with high cycling stability and capacity. RSC Adv. 2013, 3, 4914-4916. [CrossRef]

145. Rong, J.; Ge, M.; Fang, X.; Zhou, C. Solution ionic strength engineering as a generic strategy to coat graphene oxide (GO) on various functional particles and its application in high-performance lithium-sulphur (Li-S) batteries. Nano Lett. 2014, 14, 473-479. [CrossRef] [PubMed]

146. Sun, C.; Shi, L.; Fan, C.; Fu, X.; Ren, Z.; Qian, G.; Wang, Z. Bowl-like sulfur particles wrapped by graphene oxide as cathode material of lithium-sulfur batteries. RSC Adv. 2015, 5, 28832-28835. [CrossRef]

147. Zhang, J.; Yang, N.; Yang, X.; Li, S.; Yao, J.; Cai, Y. Hollow sulphur@graphene oxide core-shell composite for high-performance Li-S batteries. J. Alloy. Compd. 2015, 650, 604-609. [CrossRef]

148. Wang, J.-Z.; Lu, L.; Choucair, M.; Stride, J.A.; Xu, X.; Liu, H.-K. Sulphur-graphene composite for rechargeable lithium batteries. J. Power Sources 2011, 196, 7030-7034. [CrossRef]

149. Wei, Z.K.; Chen, J.J.; Qin, L.L.; Nemage, A.W.; Zheng, M.S.; Dong, Q.F. Two-step hydrothermal method for synthesis of sulphur-graphene hybrid and its application in lithium sulphur batteries. J. Electrochem. Soc. 2012, 159, A1236-A1239. [CrossRef]

150. Li, H.; Yang, X.; Wang, X.; Liu, M.; Ye, F.; Wang, J.; Qiu, Y.; Li, W.; Zhang, Y. Dense integration of graphene and sulphur through the soft approach for compact lithium/sulphur battery cathode. Nano Energy 2015, 12, 468-475. [CrossRef]

151. Lu, S.; Chen, Y.; Wu, X.; Wang, Z.; Li, Y. Three-dimensional sulfur/graphene multifunctional hybrid sponges for lithium-sulfur batteries with large areal mass loading. Sci. Rep. 2014, 4, 4629-4632. [CrossRef] [PubMed]

152. Xu, C.; Wu, Y.; Zhao, X.; Wang, X.; Du, G.; Zhang, J.; Tu, J. Sulfur/three-dimensional graphene composite for high performance lithium-sulfur batteries. J. Power Sources 2015, 275, 22-25. [CrossRef]

153. Zhou, G.M.; Yin, L.C.; Wang, D.W.; Li, L.; Pei, S.F.; Gentle, I.R.; Li, F.; Cheng, H.M. Fibrous hybrid of graphene and sulfur nanocrystals for high-performance lithium-sulfur batteries. ACS Nano 2013, 7, 5367-5375. [CrossRef] [PubMed]

154. Chen, F.-B.; Wang, Y.-N.; Wu, B.-R.; Xiong, Y.-K.; Liao, W.-L.; Wu, F.; Zhe, S. Preparation and electrochemical performance of activation graphene/sulfur complex cathode material for lithium-sulfur batteries. J. Inorg. Mater. 2014, 29, 627-632.

155. Huang, X.; Sun, B.; Li, K.; Chen, S.; Wang, G. Mesoporous graphene paper imobilised sulfur as a flexible electrode for lithium-sulfur batteries. J. Mater. Chem. A 2013, 1, 13484-13489. [CrossRef]

156. Xu, J.; Shui, J.; Wang, J.; Wang, M.; Liu, H.-K.; Dou, S.X.; Jeon, I.-Y.; Seo, J.-M.; Baek, J.-B.; Dai, L. Sulfur-graphene nanostructured cathodes via ball-milling for high-performance lithium-sulfur batteries. ACS Nano 2014, 8, 10920-10930. [CrossRef] [PubMed] 
157. Wang, Y.-X.; Chou, S.-L.; Liu, H.-K.; Dou, S.-X. The Electrochemical properties of high-capacity sulphur/reduced graphene oxide with different electrolyte systems. J. Power Sources 2013, 244, 240-245. [CrossRef]

158. Wang, C.; Wang, X.; Wang, Y.; Chen, J.; Zhou, H.; Huang, Y. Macroporous free-standing nano-sulfur/reduced graphene oxide paper as stable cathode for lithium-sulfur battery. Nano Energy 2015, 11, 678-686. [CrossRef]

159. Zheng, S.; Wen, Y.; Zhu, Y.; Han, Z.; Wang, J.; Yang, J.; Wang, C. In situ sulfur reduction and intercalation of graphite oxides for Li-S battery cathodes. Adv. Energy Mater. 2014, 4, 1400482-1400491. [CrossRef]

160. Evers, S.; Nazar, L.F. Graphene-enveloped sulfur in a one pot reaction: A cathode with good coulombic efficiency and high practical sulfur content. Chem. Commun. 2012, 48, 1233-1235. [CrossRef] [PubMed]

161. Sun, H.; Xu, G.-L.; Xu, Y.-F.; Sun, S.-G.; Zhang, X.; Qiu, Y.; Yang, S. A composite material of uniformly dispersed sulfur on reduced graphene oxide: Aqueous one-pot synthesis, characterization and excellent performance as the cathode in rechargeable lithium-sulfur batteries. Nano Res. 2012, 5, 726-738. [CrossRef]

162. Liu, Y.; Guo, J.; Zhang, J.; Su, Q.; Du, G. Graphene-wrapped sulfur nanospheres with ultra-high sulfur loading for high energy density lithium-sulfur batteries. Appl. Surf. Sci. 2015, 324, 399-404. [CrossRef]

163. Wu, H.; Huang, Y.; Zong, M.; Fu, H.; Sun, X. Self-assembled graphene/sulfur composite as high current discharge cathode for lithium-sulfur batteries. Electrochim. Acta 2015, 163, 24-31. [CrossRef]

164. Zhao, H.; Peng, Z.; Wang, W.; Chen, X.; Fang, J.; Xu, J. Reduced graphene oxide with ultrahigh conductivity as carbon coating layer for high performance sulphur@reduced graphene oxide cathode. J. Power Sources 2014, 245, 529-536. [CrossRef]

165. Zhang, C.; Liu, D.H.; Lv, W.; Wang, D.W.; Wei, W.; Zhou, G.M.; Wang, S.; Li, F.; Li, B.H.; Kang, F.; et al. A high-density graphene-sulfur assembly: A promising cathode for compact Li-S batteries. Nanoscale 2015, 7, 5592-5597. [CrossRef] [PubMed]

166. Zhang, C.; Lv, W.; Zhang, W.; Zheng, X.; Wu, M.-B.; Wei, W.; Tao, Y.; Li, Z.; Yang, Q.-H. Reduction of graphene oxide by hydrogen sulfide: A promising strategy for pollutant control and as an electrode for Li-S Batteries. Adv. Energy Mater. 2014, 4, 1301565-1301569. [CrossRef]

167. Xu, H.; Deng, Y.; Shi, Z.; Qian, Y.; Meng, Y.; Chen, G. Graphene-encapsulated sulfur (GES) composites with a core-shell structure as superior cathode materials for lithium-sulfur batteries. J. Mater. Chem. A 2013, 1, 15142-15149. [CrossRef]

168. Xi, K.; Kidambi, P.R.; Chen, R.; Gao, C.; Peng, X.; Ducati, C.; Hofmann, S.; Kumar, R.V. Binder free three-dimensional sulphur/few-layer graphene foam cathode with enhanced high-rate capability for rechargeable lithium sulphur batteries. Nanoscale 2014, 6, 5746-5753. [CrossRef] [PubMed]

169. Zhao, M.-Q.; Zhang, Q.; Huang, J.-Q.; Tian, G.-L.; Nie, J.-Q.; Peng, H.-J.; Wei, F. Unstacked double-layer templated graphene for high-rate lithium-sulphur batteries. Nat. Commun. 2014, 5, 3410-3417. [CrossRef] [PubMed]

170. Wang, Z.; Dong, Y.; Li, H.; Zhao, Z.; Wu, H.B.; Hao, C.; Liu, S.; Qiu, J.; Lou, X.W. Enhancing lithium-sulphur battery performance by strongly binding the discharge products on amino-functionalized reduced graphene oxide. Nat. Commun. 2014, 5, 5002-5009. [CrossRef] [PubMed]

171. Song, J.; Yu, Z.; Gordin, M.L.; Wang, D. Advanced sulfur cathode enabled by highly crumpled nitrogen-doped graphene sheets for high-energy-density lithium-sulfur batteries. Nano Lett. 2016, 16, 864-870. [CrossRef] [PubMed]

172. Huang, J.-Q.; Zhang, Q.; Wei, F. Multi-functional separator/interlayer system for high-stable lithium-sulfur batteries: Progress and prospects. Energy Storage Mater. 2015, 1, 127-145. [CrossRef]

173. Su, Y.S.; Manthiram, A. Lithium-sulphur batteries with a microporous carbon paper as a bifunctional interlayer. Nat. Commun. 2012, 3, 1166-1171. [CrossRef] [PubMed]

174. Chung, S.H.; Manthiram, A. Carbonized eggshell membrane as a natural polysulphide reservoir for highly reversible Li-S batteries. Adv. Mater. 2014, 26, 1360-1365. [CrossRef] [PubMed]

175. Chung, S.H.; Manthiram, A. A natural carbonized leaf as polysulphide diffusion inhibitor for high-performance lithium-sulfur battery cells. ChemSusChem 2014, 7, 1655-1661. [CrossRef] [PubMed]

176. Qin, F.R.; Zhang, K.; Fang, J.; Lai, Y.Q.; Li, Q.; Zhang, Z.A.; Li, J. High performance lithium sulphur batteries with a cassava-derived carbon sheet as a polysulphides inhibitor. New J. Chem. 2014, 38, 4549-4554. [CrossRef]

177. Zhang, L.Y.; Wang, Y.Y.; Peng, B.; Yu, W.T.; Wang, H.Y.; Wang, T.; Deng, B.W.; Chai, L.Y.; Zhang, K.; Wang, J.X. Preparation of a macroscopic, robust carbon-fiber monolith from filamentous fungi and its application in Li-S batteries. Green Chem. 2014, 16, 3926-3934. [CrossRef] 
178. Cao, Z.; Ma, C.; Yin, Y.; Zhang, J.; Ding, Y.; Shi, M.; Yang, S. Carbonized non-woven fabric films as adsorbing interlayers to enhance electrochemical performance of lithium-sulphur batteries. New J. Chem. 2015, 39, 9659-9664. [CrossRef]

179. Chung, S.H.; Manthiram, A. A hierarchical carbonized paper with controllable thickness as a modulable interlayer system for high performance Li-S batteries. Chem. Commun. 2014, 50, 4184-4187. [CrossRef] [PubMed]

180. Chung, S.H.; Singhal, R.; Kalra, V.; Manthiram, A. Porous carbon mat as an electrochemical testing platform for investigating the polysulphide retention of various cathode configurations in Li-S cells. J. Phys. Chem. Lett. 2015, 6, 2163-2169. [CrossRef] [PubMed]

181. Huang, Y.; Zheng, M.; Lin, Z.; Zhao, B.; Zhang, S.; Yang, J.; Zhu, C.; Zhang, H.; Sun, D.; Shi, Y. Flexible cathodes and multifunctional interlayers based on carbonized bacterial cellulose for high-performance lithium-sulfur batteries. J. Mater. Chem. A 2015, 3, 10910-10918. [CrossRef]

182. Wang, J.; Yang, Y.; Kang, F. Porous carbon nanofiber paper as an effective interlayer for high-performance lithium-sulfur batteries. Electrochim. Acta 2015, 168, 271-276. [CrossRef]

183. Wu, F.; Li, W.; Guan, L.; Ye, Y.; Qian, J.; Yang, X.; Xu, Y.; Chen, R. A polypyrrole-supported carbon paper acting as a polysulphide trap for lithium-sulfur batteries. RSC Adv. 2015, 5, 94479-94485. [CrossRef]

184. Zhang, K.; Li, Q.; Zhang, L.; Fang, J.; Li, J.; Qin, F.; Zhang, Z.; Lai, Y. From filter paper to carbon paper and toward Li-S battery interlayer. Mater. Lett. 2014, 121, 198-201. [CrossRef]

185. Zhang, Z.; Wang, G.; Lai, Y.; Li, J. A freestanding hollow carbon nanofiber/reduced graphene oxide interlayer for high-performance lithium-sulfur batteries. J. Alloy. Compd. 2016, 663, 501-506. [CrossRef]

186. Zu, C.; Su, Y.S.; Fu, Y.; Manthiram, A. Improved lithium-sulfur cells with a treated carbon paper interlayer. Phys. Chem. Chem. Phys. 2013, 15, 2291-2297. [CrossRef] [PubMed]

187. Fu, Y.; Su, Y.S.; Manthiram, A. Highly reversible lithium/dissolved polysulphide batteries with carbon nanotube electrodes. Angew. Chem. Int. Ed. 2013, 52, 6930-6935. [CrossRef] [PubMed]

188. Hwang, J.-Y.; Kim, H.M.; Lee, S.-K.; Lee, J.-H.; Abouimrane, A.; Khaleel, M.A.; Belharouak, I.; Manthiram, A.; Sun, Y.-K. High-energy, high-rate, lithium-sulphur batteries: Synergetic effect of hollow $\mathrm{TiO}_{2}$-webbed carbon nanotubes and a dual functional carbon-paper interlayer. Adv. Energy Mater. 2016, 6. [CrossRef]

189. Su, Y.S.; Manthiram, A. A new approach to improve cycle performance of rechargeable lithium-sulfur batteries by inserting a free-standing MWCNT interlayer. Chem. Commun. 2012, 48, 8817-8819. [CrossRef] [PubMed]

190. Song, J.X.; Yu, Z.X.; Xu, T.; Chen, S.R.; Sohn, H.; Regula, M.; Wang, D.H. Flexible freestanding sandwich-structured sulfur cathode with superior performance for lithium-sulfur batteries. J. Mater. Chem. A 2014, 2, 8623-8627. [CrossRef]

191. Han, X.; Xu, Y.; Chen, X.; Chen, Y.-C.; Weadock, N.; Wan, J.; Zhu, H.; Liu, Y.; Li, H.; Rubloff, G.; et al. Reactivation of dissolved polysulphides in $\mathrm{Li}-\mathrm{S}$ batteries based on atomic layer deposition of $\mathrm{Al}_{2} \mathrm{O}_{3}$ in nanoporous carbon cloth. Nano Energy 2013, 2, 1197-1206. [CrossRef]

192. Xu, G.; Yuan, J.; Tao, X.; Ding, B.; Dou, H.; Yan, X.; Xiao, Y.; Zhang, X. Absorption mechanism of carbon-nanotube paper-titanium dioxide as a multifunctional barrier material for lithium-sulfur batteries. Nano Res. 2015, 8, 3066-3074. [CrossRef]

193. Huang, J.-Q.; Zhang, B.; Xu, Z.-L.; Abouali, S.; Akbari Garakani, M.; Huang, J.; Kim, J.-K. Novel interlayer made from $\mathrm{Fe}_{3} \mathrm{C}$ /carbon nanofiber webs for high performance lithium-sulfur batteries. J. Power Sources 2015, 285, 43-50. [CrossRef]

194. Wang, X.; Wang, Z.; Chen, L. Reduced graphene oxide film as a shuttle-inhibiting interlayer in a lithium-sulfur battery. J. Power Sources 2013, 242, 65-69. [CrossRef]

195. Han, K.; Shen, J.; Hao, S.; Ye, H.; Wolverton, C.; Kung, M.C.; Kung, H.H. Free-standing nitrogen-doped graphene paper as electrodes for high-performance lithium/dissolved polysulphide batteries. ChemSusChem 2014, 7, 2545-2553. [CrossRef] [PubMed]

196. Chung, S.H.; Manthiram, A. Bifunctional separator with a light-weight carbon-coating for dynamically and statically stable lithium-sulfur batteries. Adv. Funct. Mater. 2014, 24, 5299-5306. [CrossRef]

197. Chung, S.-H.; Han, P.; Singhal, R.; Kalra, V.; Manthiram, A. Electrochemically stable rechargeable lithium-sulfur batteries with a microporous carbon nanofiber filter for polysulphide. Adv. Energy Mater. 2015, 5, 1500738-1500749. [CrossRef]

198. Chung, S.H.; Manthiram, A. High-performance Li-S batteries with an ultra-lightweight MWCNT-coated separator. J. Phys. Chem. Lett. 2014, 5, 1978-1983. [CrossRef] [PubMed] 
199. Chang, C.H.; Chung, S.H.; Manthiram, A. Effective stabilization of a high-loading sulphur cathode and a lithium-metal anode in Li-S batteries utilizing SWCNT-modulated separators. Small 2016, 12, 174-179. [CrossRef] [PubMed]

200. Chung, S.-H.; Manthiram, A. A polyethylene glycol-supported microporous carbon coating as a polysulphide trap for utilizing pure sulfur cathodes in lithium-sulfur batteries. Adv. Mater. 2014, 26, 7352-7357. [CrossRef] [PubMed]

201. Zhou, G.; Pei, S.; Li, L.; Wang, D.W.; Wang, S.; Huang, K.; Yin, L.C.; Li, F.; Cheng, H.M. A graphene-pure-sulfur sandwich structure for ultrafast, long-life lithium-sulfur batteries. Adv. Mater. 2014, 26, 625-631. [CrossRef] [PubMed]

202. Balach, J.; Jaumann, T.; Klose, M.; Oswald, S.; Eckert, J.; Giebeler, L. Functional mesoporous carbon-coated separator for long-life, high-energy lithium-sulfur batteries. Adv. Funct. Mater. 2015, 25, 5285-5291. [CrossRef]

203. Balach, J.; Jaumann, T.; Klose, M.; Oswald, S.; Eckert, J.; Giebeler, L. Improved cycling stability of lithium-sulfur batteries using a polypropylene-supported nitrogen-doped mesoporous carbon hybrid separator as polysulphide adsorbent. J. Power Sources 2016, 303, 317-324. [CrossRef]

204. Zhang, Z.; Wang, G.; Lai, Y.; Li, J.; Zhang, Z.; Chen, W. Nitrogen-doped porous hollow carbon sphere-decorated separators for advanced lithium-sulfur batteries. J. Power Sources 2015, 300, 157-163. [CrossRef]

205. Zhao, D.; Qian, X.; Jin, L.; Yang, X.; Wang, S.; Shen, X.; Yao, S.; Rao, D.; Zhou, Y.; Xi, X. Separator modified by Ketjen black for enhanced electrochemical performance of lithium-sulfur batteries. RSC Adv. 2016, 6, 13680-13685. [CrossRef]

206. Wang, Q.; Wen, Z.; Yang, J.; Jin, J.; Huang, X.; Wu, X.; Han, J. Electronic and ionic co-conductive coating on the separator towards high-performance lithium-sulfur batteries. J. Power Sources 2016, 306, 347-353. [CrossRef]

207. Zhang, Y.; Miao, L.; Ning, J.; Xiao, Z.; Hao, L.; Wang, B.; Zhi, L. A graphene-oxide-based thin coating on the separator: an efficient barrier towards high-stable lithium-sulfur batteries. 2D Mater. 2015, 2, 024013. [CrossRef]

208. Zhuang, T.Z.; Huang, J.Q.; Peng, H.J.; He, L.Y.; Cheng, X.B.; Chen, C.M.; Zhang, Q. Rational integration of polypropylene/graphene oxide/Nafion as ternary-layered separator to retard the shuttle of polysulphides for lithium-sulfur batteries. Small 2016, 12, 381-389. [CrossRef] [PubMed]

209. Peng, H.-J.; Wang, D.-W.; Huang, J.-Q.; Cheng, X.-B.; Yuan, Z.; Wei, F.; Zhang, Q. Janus separator of polypropylene-supported cellular graphene framework for sulfur cathodes with high utilization in lithium-sulfur batteries. Adv. Sci. 2016, 3. [CrossRef] [PubMed]

210. Wei, H.; Ma, J.; Li, B.; Zuo, Y.; Xia, D. Enhanced cycle performance of lithium-sulfur batteries using a separator modified with a PVDF-C layer. ACS Appl. Mater. Interface 2014, 6, 20276-20281. [CrossRef] [PubMed]

211. Wang, G.; Lai, Y.; Zhang, Z.; Li, J.; Zhang, Z. Enhanced rate capability and cycle stability of lithium-sulfur batteries with a bifunctional MCNT@PEG-modified separator. J. Mater. Chem. A 2015, 3, 7139-7144. [CrossRef]

212. Wang, Z.; Zhang, S.; Zhang, L.; Lin, R.; Wu, X.; Fang, H.; Ren, Y. Hollow spherical carbonized polypyrrole/sulphurcomposite cathode materials for lithium/sulphur cells with long cycle life. J. Power Sources 2014, 248, 337-342. [CrossRef]

213. Jin, J.; Wen, Z.; Ma, G.; Lu, Y.; Rui, K. Mesoporous carbon/sulphur composite with polyaniline coating for llithium sulphur batteries. Solid State Ion. 2014, 262, 170-173. [CrossRef]

214. Yang, Z.Z.; Wang, H.Y.; Lu, L.; Wang, C.; Zhong, X.B.; Wang, J.G.; Jiang, Q.C. Hierarchical TiO 2 spheres as highly efficient polysulphide host for lithium-sulfur batteries. Sci. Rep. 2016, 6. [CrossRef]

215. An, T.; Deng, D.; Lei, M.; Wu, Q.; Tian, Z.; Zheng, M.-S.; Dong, Q.-F. MnO modified carbon nanotubes as sulphur host with enhanced performance in Li/S batteries. J. Mater. Chem. A 2016, 4, 12858-12864. [CrossRef]

(C) 2016 by the authors; licensee MDPI, Basel, Switzerland. This article is an open access article distributed under the terms and conditions of the Creative Commons Attribution (CC-BY) license (http://creativecommons.org/licenses/by/4.0/). 